WSRC-TR-93-565

Derivative Classifier

Summary Report of the Drilling Technologies Tested at the Integrated Demonstration Project for Cleanup of Organic Contaminants in Soils and Groundwater at Non-arid Sites

Approved by:

DBraru- Lunas

D.B. Moore-Shedrow, Manager

Environmental Sciences Section

November 1993

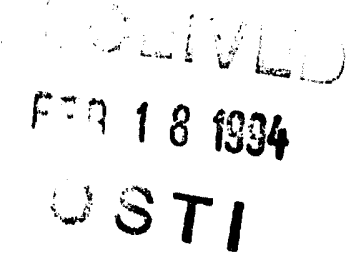

Westinghouse Savannah River Company

Savannah River Technology Center

Aiken, South Carolina 29808

Prepared for the Department of Energy under Contract DE-AC09-89SR18035
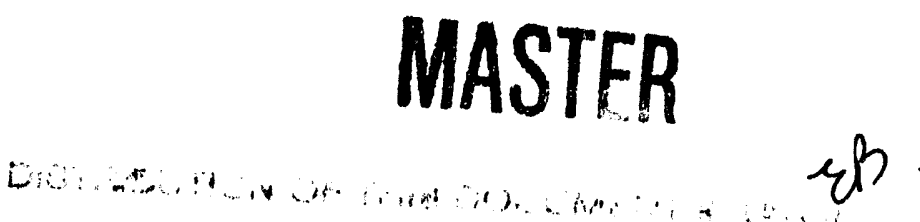
WSRC-TR-93-565

\section{SUMMARY REPORT OF THE DRILLING TECHNOLOGIES TESTED AT THE INTEGRATED DEMONSTRATION PROJECT FOR CLEANUP OF ORGANIC CONTAMINANTS IN SOILS AND GROUNDWATER AT NON-ARID SITES}

OCTOBER 15, 1993

Westinghouse Savannah River Company

Savannah River Site

Aiken, South Carolina 29808 
THIS PAGE LEFT INTENTIONALLY LEFT BLANK

1

1

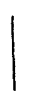

1

1

1

1 


\section{DISCLAIMER}

This report was prepared as an account of work sponsored by an agency of the United States Government. Neither the United States Government nor any agency thereof, nor any of their employees, makes any warranty, express or implied, or assumes any legal liability or responsibility for the accuracy, completeness, or usefulness of any information, apparatus, product, or process disclosed, or represents that its use would not infringe privately owned rights. Reference herein to any specific commercial product, process, or service by trade name, trademark, manufacturer, or otherwise does not necessarily constitute or imply its endorsement, recommendation, or favoring by the United States Government or any agency thereof. The views and opinions of authors expressed berein do not necessarily state or reflect those of the United States - Government or any agency thereof.

This repon has been reproduced directly from the best available copy.

Available to DOE and DOE contractors from the Office of Scientific and Technical Information. P. O. Box 62, Oak Ridge. TN 37831; prices available from (615) $576-8401$.

Available to the public from the National Technical Information Service, U. S. Department of Commerce. 5285 Port Royal Rd., Springfield, VA 22161 
Summary Report of the Drilling Technologies Tested at the Integrated Demonstration Project for Cleanup of Organic Contaminants in Soils and Groundwater at Non-Arid Sites

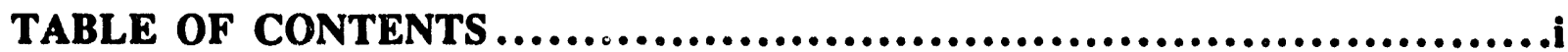

LIST OF FIGURES $\ldots . \ldots \ldots \ldots \ldots \ldots \ldots \ldots \ldots \ldots \ldots \ldots \ldots \ldots \ldots \ldots \ldots \ldots \ldots \ldots \ldots$ iii

LIST OF ABBREVIATIONS, ACRONYMS, AND INITIALS ...............v

1.0 EXECUTIVE SUMMARY $\ldots \ldots \ldots \ldots \ldots \ldots \ldots \ldots \ldots \ldots \ldots \ldots \ldots \ldots \ldots \ldots . . \ldots \ldots$

2.0 INTRODUCTION $\ldots \ldots \ldots \ldots \ldots \ldots \ldots \ldots \ldots \ldots \ldots \ldots \ldots \ldots \ldots \ldots \ldots \ldots \ldots . . \ldots \ldots \ldots$

3.0 INTEGRATED DEMONSTRATION PROJECT SITE

DESCRIPTION................................................3 1

3.1 Regional Geologic Setting............................................3-1

3.2 A/M-Area Hydrogeologic and Hydrostratigraphic Setting............3-2

3.2.1 Santee Formation...........................................3-4

3.2.2 Dry Branch Formation ......................................3.5

3.2.3 Tobacco Road Formation ...................................3-5

3.2.4 "Upland Unit".............................................3-6

4.0 DESCRIPTION OF DIRECTIONAL DRILLING SYSTEMS............4-1

4.1 General State of the Horizontal Well Industry...........................4-1

4.2 Short Radius Drilling Technology ..................................4-3

4.2.1 Drilling Rig.............................................4-3

4.2.2 Down-Hole Drilling Assembly.............................4-3

4.2.3 Drill Rods..................................................4-5

4.2.4 Drilling Fluid System.......................................4-5

4.2.5 Well Materials and Installation............................4-7

4.3 Modified Petroleum Industry Drilling Technology...................4-8

4.3.1 Drilling Rig..............................................4-8

4.3.2 Down-Hole Drilling Assembly............................4-8

4.3.3 Drill Rods................................................4.10

4.3.4 Drilling Fluid System....................................4-11 
Summary Report of the Drilling Technologies Tested at vo Integrated Demonstration Project for Cleanup of Organic Contaminants in Soils and Groundwater at Non-Arid Sites

\section{LIST OF TABLES}

1.1 List of Advantages and Disadvantages of Each Technology .........1-3

5.1 Summary of Horizontal Environmental Well Installation -

Planned vs. Actual...............................................5-19

6.1 Associated Cost for Drilling Projects.................................6-5

7.1 List of Advantages and Disadvantages of Each Technology ..........7-2 
Summary Report of the Drilling Technologies Tested at the Integrated Demonstration Project for Cleanup of Organic Contaminants in Soils and Groundwater at Non-Arid Sites

\section{LIST OF FIGURES}

3.1 Location of the SRS in South Carolina..............................3

3.2 Location of M-Area Settling Basin Hazardous Waste

Management Facility

3.3 Physiographic Provinces of the Eastern United States.............. 3-10

3.4 Physiographic Subprovinces of the Atlantic Coastal Plain ......... 3-11

3.5 Comparison of Chronostratigraphic, Lithostratigraphic, and

Hydrostratigraphic Units at the SRS .............................3 3-13

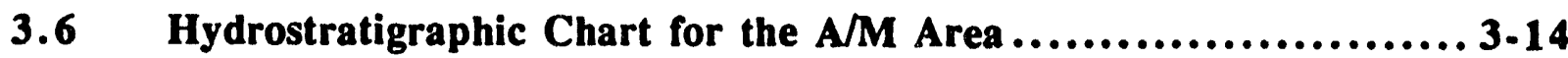

3.7 Schematic of M-Area Geology with Relative Locations of

Horizontal Wells .................................................... 3-15

4.1.1 Diagram (in Cross Section) of A Typica! Horizontal Well

Layout........................................................4-22

4.2.1 Short-Radius Technology - Curved Drill Guide.....................4-23

4.2.2 Short-Radius Technology - Schematic Diagram of Whipstock

Assembly ...................................................... 4-24

4.2.3 Short-Radius Technology - Rigid Drill Mandrel....................4-25

4.2.4 Short-Radius Technology - AMH-1 Horizontal Well

Construction Diagram (Water Table Well) ......................4.26

4.2.5 Short-Radius Technology - AMH.2 Horizontal Well

Construction Diagram (Vadose Zone Well) ......................4-27

4.3.1 Modified Petroleum Industry Technology -

Non-Magnetic Bottom Hole Assembly (BHA) ................... 4-28

4.3.2 Modified Petroleum Industry Technology -

Schematic of Down-Hole Motor with Stabilizers...................4.29

4.3.3 Modified Petroleum Industry Technology -

Well Section Orientation and Associated Technology.............4-30

4.3.4 Modified Petroleum Industry Technology -

AMH-3 Horizontal Well Construction Diagram (Water Table

Well) 
Summary Report of the Drilling Technologies Tested at the Integrated Demonstration Project for Cleanup of Organic Contaminants in Soils and Groundwater at Non-Arid Sites

4.3.5 Modified Petroleum Industry Technology -

AMH-4 Horizontal Well Construction Diagram (Vadose Zone

Well).

4.4.1 Utility Industry Compactional Drilling Technology -

Oblique View of X-810 Experimental Drilling Rig...

4.4.2 Utility Industry Compactional Drilling Technology -

Down-Hole Assembly

4.4.3 Utility Industry Compactional Drilling Technology -

Patented Directional Drilling Tool.

4.4.4 Utility Industry Compactional Drilling Technology -

AMH-5 Horizontal Well Construction Diagram

4.5.1 River Crossing Industry Drilling Technology -

Oblique View of MC-90 Drilling Rig

4.5.2 River Crossing Industry Drilling Technology -

Down-Hole Drilling Assembly

4.5.3 River Crossing Industry Drilling Technology -

Directional Drilling Tool.

4.5.4 River Crossing Industry Drilling Technology -

Magnetic Guidance System (MGS)

4.5.5 River Crossing Industry Drilling Technology -

Drill String Assembly

4.5.6 River Crossing Industry Drilling Technology -

Nine-Inch Drill Bit Attached to Washover Pipe .....................4-51

4.5.7 River Crossing Industry Drilling Technology -

Mud System Set-up.

4.5.8 River Crossing Industry Drilling Technology -

AMH-6 Horizontal Well Construction Diagram

4.5.9 River Crossing Industry Drilling Technology -

AMH-7 Horizontal Well Construction Diagram 
Summary Report of the Drilling Technologies Tested at the Integrated Demonstration Project for Cleanup of Organic Contaminants in Soils and Groundwater at Non-Arid Sites

\section{LIST OF ABBREVIATIONS, ACRONYMS, AND INITIALS}

$\begin{array}{ll}\text { BHA } & \text { Non-Magnetic Bottom Hole Assembly } \\ \text { CEC } & \text { EVI Cherrington Environmental Corporation } \\ \text { DHM } & \text { down-hole motor } \\ \text { DOE } & \text { Department of Energy } \\ \text { ECEC } & \text { Eastman Christensen Environmental Corporation } \\ \text { ECES } & \text { Eastman Cherrington Environmental } \\ \text { EOC } & \text { end of curve } \\ \text { ft-lbs } & \text { foot-pounds } \\ \text { gpm } & \text { gallons per minute } \\ \text { HDPE } & \text { high density polyethylene } \\ \text { ID } & \text { inside diameter } \\ \text { IDP } & \text { Integrated Demonstration Project } \\ \text { lbs } & \text { pounds } \\ \text { lbs/gal } & \text { pounds per gallon } \\ \text { KOP } & \text { kick-off point } \\ \text { MD } & \text { measured depth } \\ \text { MGS } & \text { Magnetic Guidance System } \\ \text { OD } & \text { outside diameter } \\ \text { PHPA } & \text { partially hydrolized polyacrylamide } \\ \text { psi } & \text { pounds per square inch } \\ \text { PVC } & \text { polyvinyl chloride } \\ \text { RCRA } & \text { Resource Conservation and Recovery Act } \\ \text { Tpms } & \text { revolutions per minute } \\ \text { SAIC } & \text { Science Applications International Corporation } \\ \text { SNL } & \text { Sandia National Laboratories } \\ \text { SRS } & \text { Savannah River Site } \\ \text { SRTC } & \text { Savannah River Technology Center } \\ \text { TFI } & \text { tool face indicator } \\ \text { VD } & \text { vertical depth } \\ \text { VOCs } & \text { volatile organic compounds } \\ \text { WSRC } & \text { Westinghouse Savannah River Company } \\ & \end{array}$


Summary Report of the Drilling Technologies Tested at the Integrated Demonstration Project for Cleanup of Organic Contaminants in Soils and Groundwater at Non-Arid Sites

\section{THIS PAGE LEFT INTENTIONALLY LEFT BLANK}


Summary Report of the Drilling Technologies Tested at the Integrated Demonstration Project for Cleanup of Organic Contaminants in Soils and Groundwater at Non-Arid Sites

\subsection{EXECUTIVE SUMMARY}

The Department of Energy's (DOE) Office of Technology Development initiated an integrated demonstration of innovative technologies and systems for cleanup of volatile organic compounds (VOCs) in soils and groundwater. One portion of the integrated technology demonstration was a demonstration of directional drilling technologies at the Savannah River Site (SRS). The objective of the drilling demonstration was a demonstration of multiple directional drilling technologies. The technologies were compared and evaluated in terms of technical performance and cost effectiveness. Petroleum horizontal well technology, utility horizontal drilling technology, and river crossing directional drilling were demonstrated. The petroleum industry directional drilling technology was demonstrated by Eastman Christensen Environmental Corporation. Eastman Christensen Environmental Corporation directionally drilled and installed four horizontal wells in the M-Area using a short radius drilling technology and a modified petroleum (down-hole motor) technology. Charles Machine Works working with Sandia National Laboratory demonstrated utility industry directional drilling technology by installing one horizontal well in the M-Area. EVI Cherrington Environmental Corporation demonstrated the river crossing directional drilling technology installing two horizontal wells beneath the M-Area Settling Basin. Eastman Christensen Environmental Corporation and EVI Cherrington Environmental Corporation have recently merged to form Eastman Cherrington Environmental.

Horizontal environmental wells were successfully installed during all the demonstrations. Difficulties were encountered and overcome during each demonstration. Each directional drilling technology demonstrated offered advantages and disadvantages with respect to geological and logistical conditions found at the SRS. A summary of the advantages, disadvantages, and cost for the drilling technolngies are listed in Table 1.1.

The short radius drilling technology was developed in the petroleum industry and was used at this site with little modification. A recent survey of the horizontal environmental well industry did not find another site where this technology was used to install a horizontal environmental well. 
Summary Report of the Drilling Technologies 'Tested at the Integrated Demonstration Project for Cleanup of Organic Contaminants in Soils and Groundwater at Non-Arid Sites

The modified petroleum industry drilling technology has been further modified since the SRS demonstration for drilling in shallow, unconsolidated formations. The major modification is that an additive to the drilling fluid allows the well screen to be installed in an open borehole. This modification does not require the well screen to be pulled into the hole behind the drill motor. This technology is currently being used to install horizontal environmental wells.

The utility industry drilling technology demonstration has lead to a new drilling rig product line for Charles Machine Works. The prototype drilling rig and drilling tool are currently being used to install horizontal environmental wells.

The river crossing industry drilling technology used during this project has also undergone modification. The washover drilling pipe that proved inadequate during the project has been replaced with stronger pipe by the company that conducted the demonstration. It must be noted that the technique used during this project is one of many techniques used in the river crossing industry to install pipes in the subsurface. 
Summary Report of the Drilling Technologies Tested at the Integrated Demonstration Project: for Cleanup of Organic Contaminants in Soils and Groundwater at Non-Arid Sites

\begin{tabular}{|c|c|c|c|}
\hline $\begin{array}{l}\text { Short Radius } \\
\text { Technology }\end{array}$ & $\begin{array}{l}\text { Modified } \\
\text { Petroleum } \\
\text { Technology }\end{array}$ & $\begin{array}{l}\text { Utility } \\
\text { Technology }\end{array}$ & $\begin{array}{l}\text { River Crossing } \\
\text { Technology }\end{array}$ \\
\hline \multicolumn{4}{|c|}{ Advantages } \\
\hline $\begin{array}{l}\text { Minimum Step-off } \\
\text { Distance }\end{array}$ & Shor Step-off Distance & $\begin{array}{l}\text { Minimum Drilling } \\
\text { Fluids }\end{array}$ & $\begin{array}{l}\text { Maximum Borehole } \\
\text { Control }\end{array}$ \\
\hline \multirow[t]{4}{*}{$\begin{array}{l}\text { Can Drill in } \\
\text { Consolidated Formations }\end{array}$} & $\begin{array}{l}\text { Can Drill in } \\
\text { Consolidated Formations }\end{array}$ & $\begin{array}{l}\text { Minimum Secondary } \\
\text { Waste }\end{array}$ & $\begin{array}{l}\text { Maximum Down-hole } \\
\text { Directional Control }\end{array}$ \\
\hline & & $\begin{array}{l}\text { Good Down-hole } \\
\text { Directional Control }\end{array}$ & $\begin{array}{l}\text { Maximum Flexibility in } \\
\text { Well Materials }\end{array}$ \\
\hline & & $\begin{array}{l}\text { Flexibility in Well } \\
\text { Materials }\end{array}$ & May Install Filter Pack \\
\hline & & Minimum Set-up Area & $\begin{array}{l}\text { Can Drill in } \\
\text { Consoildated Formations }\end{array}$ \\
\hline \multicolumn{4}{|c|}{ Disadvantages } \\
\hline Large Set-up Area & Large Set-up Area & $\begin{array}{l}\text { Limited to } \\
\text { Unconsolidated } \\
\text { Formations }\end{array}$ & Large Sel-up Area \\
\hline $\begin{array}{l}\text { High Volume of } \\
\text { Secondary Waste }\end{array}$ & $\begin{array}{l}\text { High Volume of } \\
\text { Secondary Waste }\end{array}$ & Longer Step-off Distance & $\begin{array}{l}\text { High Volume of } \\
\text { Secondary Waste }\end{array}$ \\
\hline $\begin{array}{l}\text { Doesn't Perform Well in } \\
\text { Unconsolidated } \\
\text { Formations }\end{array}$ & $\begin{array}{l}\text { Well Installation } \\
\text { Depends Heavily on } \\
\text { Drilling Fluid System }\end{array}$ & $\begin{array}{l}\text { Borehole Skin Damage } \\
\text { May be Extensive in } \\
\text { Clay Formations }\end{array}$ & Longer Step-off Distance \\
\hline \multicolumn{4}{|l|}{$\begin{array}{l}\text { Poos Down-hole } \\
\text { Directional Control }\end{array}$} \\
\hline \multicolumn{4}{|l|}{$\begin{array}{l}\text { Lack of Borehole Control } \\
\text { During Well Installation }\end{array}$} \\
\hline \multicolumn{4}{|c|}{$\begin{array}{l}\text { Projected Cost for Drilling Compared to Industry Average } \\
\text { Costs are in dollar per foot of installed well }\end{array}$} \\
\hline $\begin{array}{c}\text { Project }-\$ 1255 \\
\text { Industry }-\$ 150-\$ 250\end{array}$ & $\begin{array}{c}\text { Project - } \$ 299 \\
\text { Industry - } \$ 150 \text { - } \$ 250\end{array}$ & $\begin{array}{l}\text { Work performed under } \\
\text { industrial partnership. } \\
\text { No drilling costs } \\
\text { submitted } 10 \text { WSRC }\end{array}$ & $\begin{array}{l}\text { Project - \$160 } \\
\text { Industry - \$227 }\end{array}$ \\
\hline
\end{tabular}

Table 1.1 List of Advantages and Disadvantages of Each Technology 
Summary Report of the Drilling Technologies Tested at the Integrated Demonstration Project for Cleanup of Organic Contaminants in Soils and Groundwater at Non-Arid Sites

\section{THIS PAGE LEFT INTENTIONALLY LEFT BLANK}


Summary Report of the Drilling Technologies Tested at the Integrated Demonstration Project for Cleanup of Organic Contaminants in Soils and Groundwater at Non-Arid Sites

\subsection{INTRODUCTION}

The Department of Energy's (DOE's) Office of Technology Development initiated an integrated demonstration of innovative technologies and systems for cleanup of volatile organic compounds (VOCs) in soil and groundwater at SRS. The overall goal of the program is the demonstration of multiple technologies and systems in the fields of drilling, characterization, monitoring, and remediation at a single test bed. Transfer of demonstration information to DOE environmental restoration management, to other federal agencies, and to the national environmental industry is a critical part of the program.

Horizontal environmental well installation technology was one of the remediation technologies that was demonstrated at SRS. Four distinctly different systems of directional drilling and horizontal well installations were successfully demonstrated and evaluated. The four systems were developed in the petroleum industry, the river crossing industry, and the utility industry (all four systems are described in Section 4.0). The transfer of information concerning the horizontal environmental well installations has been facilitated by publishing a series of reports describing each individual demonstration. The reports may be obtained by contacting the Office of Technology Transfer, Westinghouse Savannah River Company (WSRC). This is the final report in the series and provides a comprehensive evaluation of all four systems.

The objectives of this report are to summarize the strengths and weaknesses of each drilling technology, describe and compare the problems encountered by each drilling technology, compare the compatibility of each technology with varying logistical and geological conditions, and discuss the expense of using each technology. This report is designed to be a horizontal environmental well reference document for the environmental remediation industry. An environmental problem holder may use this report to evaluate a directional drilling technology for use at his/her site.

The report is divided into nine sections that are described below.

1. Executive Summary - This section contains a report summary

2. Introduction - This section contains report objectives and format 
Summary Report of the Drilling Technologies Tested at the Integrated Demonstration Project for Cleanup of Organic Contaminants in Soils and Groundwater at Non-Arid Sites

3. Integrated Demonstration Project Site Description - This section contains a site description, history, and geologic setting

4. Description of Drilling Technologies - This section contains a summary of the four drilling technologies with emphasis on similarities and differences between the technologies.

5. Drilling Technologies Performance - This section contains a summary of the strengths and weaknesses of each drilling technology, a description and comparison of the problems encountered by each drilling technology, and a comparison of the compatibility of each technology with varying logistical and geological conditions

6. Cost Comparison - This section contains a comparison of the costs of each of the drilling technology demonstrations and a discussion of potential cost savings measures.

7. Conclusions - This section contains a summary of the conclusions presented in the previous two sections.

8. Recommendations - This section contains recommendation on future studies concerning horizontal environmental well installation.

The sections described above have varying degrees of autonomy; Sections 4, 5, 6, and 7 were prepared to be read independently without risk of losing meaning in the text.

The information found in this report was obtained from the following four SRS reports:

Kaback, D.S., et.al., August 1989 Well Completion Report on Installation of Horizontal Wells for In-Situ Remediation Tests, WSRC-RP-89-784

WSRC, December 1992, Demonstration of Eastman Christensen Horizontal Drilling System Integrated Demonstraton Site Savannah River Site WSRC-TR-92-577

WSRC, December 1992, Demonstration of A Utility Indusrtry Horizontal Drilling System: Horizontal Well AMH-5 Installation Report WSRC-TR-93-008

WSRC, May 1993, Demonstration of River Crossing Technology for Installation of Environmental Horizontal Wells: AMH-6 and AMH-7 Installation Report WSRC-TR-93-387 
Summary Report of the Drilling Technologies Tested at the Integrated Demonstration Project for Cleanup of Organic Contaminants in Soils and Groundwater at Non-Arid Sites

\subsection{INTEGRATED DEMONSTRATION PROJECT SITE DESCRIPTION}

The M Area ( $3 / 700$ Area), located in the northwestern portion of SRS (Fig. 3.1), is the site of the metals fabrication facility where fuel targets for the reactors were fabricated. The M-Area Settling Basin was used as a settling basin for metal-rich wastes that contained solvents. Hydrologic investigations at SRS have shown that M-Area operations resulted in the contamination of the groundwater with VOCs near the M-Area Settling Basin (Fig. 3.2). The contamination at this site resulted from the leakage of waste solvents from the M-Area Settling Basin into the Vadose zone with subsequent gravity-driven migration of the contaminants into the groundwater. The M-Area Settling Basin is now closed and capped according to Resource Conservation and Recovery Act (RCRA) guidelines. A remedial action program consisting of groundwater pumping from eleven vertical recovery wells, followed by above-ground airstripping in a central tower, was implemented in 1985 to address groundwater contamination in M Area.

\subsection{Regional Geologic Setting}

SRS is located in the Atlantic Coastal Plain Physiographic Province (Fig. 3.3). Within the Atlantic Coastal Plain Province, SRS lies on the Aiken Plateau (Fig. 3.4) which is bounded by the Savannah and Congaree Rivers. The surface of the Aiken Plateau is dissected by streams and is characterized by broad, interfluvial areas with narrow steep-sided valleys.

The Atlantic Coastal Plain is comprised of a wedge of southeast-dipping unconsolidated and semiconsolidated sediments which increase in thickness from zero at the Fall Line to more than 4,000 feet near the Atlantic Coast. These sediments range from Late Cretaceous (100 million years) to Holocene (present) in age, and extend to the seaward edge of the Continental Shelf. The Atlantic Coastal Plain sediments generally consist of strata of gravel, sand, silt, clay, and limestone, which were deposited in a variety of fluvial, deltaic, and marine depositional environments. The base of the Atlantic Coastal Plain sediments lies unconformably on top of crystalline, metamorphic, and granitic rocks in the northern portion of SRS and on top of Triassic sediments, deposited in a rift basin, in the southern part of SRS. The Atlantic Coastal Plain sediments have been extensively studied at SRS, and many lithologic and 
Summary Report of the Drilling Technologies Tested at the Integrated Demonstration Project for Cleanup of Organic Contaminants in Soil and Groundwater at Non-Arid Sites

hydrostratigraphic names have been applied to these sediments. Figure 3.5 illustrates a comparison of chronostratigraphic, lithostratigraphic, and hydrostratigraphic units. For the purpose of this report, the A/M-Area hydrogeologic setting is described using hydrostratigraphic nomenclature and the vadose zone, where most of the horizontal drilling occurred, is described using lithostratigraphic nomenclature.

\subsection{A/M-Area Hydrogeologic and Hydrostratigraphic Setting}

In A/M Area, the Atlantic Coastal Plain hydrogeologic province consists of the FloridanMidville Aquifer System which includes the McQueen Branch Aquifer, the Crouch Branch Aquifer, and the Steed Pond Aquifer (Fig. 3.6).

The majority of the monitoring wells within A/M Area are constructed in water-bearing sediments overlying the McQueen Branch Confining Unit. The Crouch Branch Aquifer, which overlies the McQueen Branch Confining Unit, is continuous beneath most of the Area. Beneath the Integrated Demonstration Project (IDP) Site at MSB-2, the top of the Crouch Branch Aquifer lies 275 feet below land surface. The Crouch Branch Aquifer is characterized by tan, gray, white, and yellow, very poorly sorted to well-sorted, medium to coarse-grained, locally pebbly sand. Based on third quarter 1991 water level data, horizontal hydraulic gradients show a southwesterly direction of groundwater flow in the vicinity of the IDP Site. The Crouch Branch Confining Unit thins northward and eventually pinches out north of the northern SRS boundary, where the Crouch Branch Aquifer and the overlying Steed Pond Aquifer coalesce to form the Hollow Creek Aquifer (Fig. 3.6).

The Crouch Branch Confining Unit separates the underlying Crouch Branch Aquifer from the overlying Steed Pond Aquifer. Within the central and southern portions of $A / M$ Area, including the IDP Site, the Crouch Branch Confining Unit, from its base to the top of the unit, can be subdivided as follows: 


\section{Hydrostratigraphic Zone}

"lower clay" confining zone

"middle sand" aquifer zone

"upper clay" confining zone
Depth (in feet) to Top of Zone at MSB-2
Thickness (in feet)

of Zone at MSB-2

The entire Crouch Branch Confining Unit thins in a northerly direction, and when the "upper clay" confining zone is absent, the "middle sand" aquifer zone merges with the overlying Steed Pond Aquifer north of the IDP Site. Within the southern to central portions of A/M Area, including the IDP Site, the Steed Pond Aquifer, from its base to the top of the aquifer, includes the following:

\section{Hydrostratigraphic Zone}

"Lost Lake" aquifer zone

"green clay" confining zone

"M-Area" aquifer zone

\section{Depth (in feet) to Top Thickness (in feet) of Zone at MSB-2 of Zone at MSB-2}

145

143

122
66

2

21

The Steed Pond Aquifer is characterized by yellow, tan, orange, and brown, loose to slightly indurated, fine to coarse-grained, moderately to well-sorted pebbly sand interbedded with occasional clay and clayey sand beds. Based on third quarter 1991 water level data, horizontal hydraulic gradients show a southerly to southwesterly direction of groundwater flow in the vicinity of the IDP site.

In the central and northem portion of A/M Area, the "green clay" confining zone thins and grades from a clay to a clayey silty sand. The "green clay" confining zone has also been referred to as the "200-ft clay" by Eddy and others (1991). The overlying "M-Area" aquifer zone and the underlying "Lost Lake" aquifer zone combine to form the undifferentiated Steed 
Summary Report of the Drilling Technologies Tested at the Integrated Demonstration Project for Cleanup of Organic Contaminants in Soil and Groundwater at Non-Arid Sites

Pond Aquifer north of the IDP site. Figure 3.7 depicts the hydrogeologic conditions from the vadose zone to the upper portion of the Steed Pond Aquifer, underlying the IDP site.

Overlying the "M-Area" aquifer zone is the vadose zone. The vadose zone underlying the M-Area Settling Basin includes portions of the Santee Formation, the Dry Branch Formation, Tobacco Road Formation, and the" Upland unit." These formations are described from the base of the vadose zone (water table) to iand surface.

\subsubsection{Santee Formation}

In A/M Area, the Santee Formation varies in thickness from 30 to 45 feet. Below the M-Area Settling Basin, the Santee Formation is 43 feet thick at MHT-3C, and the top of the formation lies 103 feet below land surface. It is composed of brown, tan, and yellowish orange, fine to coarse, poorly to well-sorted sands and interbedded with clayey sand, sandy clay, and clay. It is distinguished from the cleaner sands of the overlying Dry Branch Formation by a higher gamma-ray count on geophysical logs. Underlying the M-Area Settling Basin, the Santee Formation is partially saturated with a static water level of approximately 130 feet below ground surface.

Both AMH-6 and AMH-7 are screened near the top of the Santee Formation. AMH-3 is screened near the base of the Santee Formation, slightly above the Green Clay. The screen zone for AMH-1 begins near the base of the Santee Formation, crosses down through the green Clay, and into the underlying Congaree Formation. Figure 3-7 illustrates the relationship of all installed screen zones to the formations and the zone of saturation. Drilling became difficult during the installation of both AMH-6 and AMH-7 as each borehole was emerging from the radius of curvature. This point appears to correspond to the contact between the Santee Formation and the overlying Dry Branch Formation. The Santee Formation has a higher clay content and numerous clay stringers in comparison to the relatively clean sands of the Dry Branch Formation. This increase in clay content probably accounted for the difficulty in penetration of the drill bit. 
Summary Report of the Drilling Technologies Tested at the Integrated Demonstration Project for Cleanup of Organic Contaminants in Soils and Groundwater at Non-Arid Sites

\subsubsection{Dry Branch Formation}

The Dry Branch Formation crops out in stream valleys, and the thickness varies from 0 to 110 feet in A/M-Area wells. Below the M-Area Settling Basin, the Dry Branch Formation is 35 feet thick at MHT-3C, and the top of the formation lies 68 feet below ground surface. Sand of the Dry Branch Formation probably accumulated in a shallow marine environment. Jacksonian (Late Eocene) fossils have been found in the formation in downdip SRS wells, and the specific formation was traced into the A/M Area by correlating it with lithologic and geophysical logs.

The Dry Branch Formation is composed of orange, brown, tan, and yellow, fine to coarse, poorly to well-sorted quartz sand. Pebbly layers are common, and induration is slight to moderate. The Twiggs Clay Member of the Dry Branch Formation, or "Tan Clay" as it has been referred to in previous SRS documents, is difficult to map within the Area, but clay that is lithologically similar to the Twiggs Clay Member is present at various stratigraphic intervals within the Dry Branch Formation (Fig. 3-7). This clay lithofacies, interbedded with sand and clayey sand, which is characterized as tan, light gray, and brown, ranges from 12 to 34 feet thick and occurs at approximately 80 feet below ground surface beneath the M-Area Settling Basin (Science Applications International Corporation [SAIC], 1992) but is not laterally continuous over long distances. It has been referred to as the "Tan Clay" in previous SRS reports and as the "270-ft clay" by Eddy and others (1991). The top of the Dry Branch Formation is identified on geophysical logs where a low gamma-ray count in the cleaner sand of the Dry Branch Formation sharply increases in the more argillaceous sand of the Tobacco Road Formation. On most lithologic logs, the contact, which is probably conformable, is marked by an increase in silt and clay percentage. The Dry Branch Formation and the overlying formations are unsaturated beneath the M-Area Settling Basin. The screen zone for AMH-4 is installed near the base of the Dry Branch Formation.

\subsubsection{Tobacco Road Formation}

The Tobacco Road Formation crops out in several places in A/M Area. The formation has a higher silt and clay content, and thus a lower permeability than the Dry Branch Formation. The Tobacco Road Formation was probably deposited in a shallow marine environment and has 
Summary Report of the Drilling Technologies Tested at the Integrated Demonstration Project for Cleanup of Organic Contaminants in Soil and Groundwater at Non-Arid Sites

been dated as late Jacksonian (late Late Eocene) downdip from SRS in Georgia (Huddleston and Hetrick, 1985). Nystrom and Willoughby (1982) have traced the formation into the vicinity of the A/M Area by correlation of outcrops and have dated it as Claibornian, not Jacksonian.

Beneath the M-Area Settling Basin, the Tobacso Road Formation is 15 feet thick at MHT-3C, and the top of the formation lies $\mathbf{5 3}$ feet below ground surface. The top of the Tobacco Road Formation is identified where comparatively well-sorted sand is overlain by more poorly sorted sand, pebbly sand, and clay of the "Upland unit". The Tobacco Road Formation is composed almost entirely of orange, red, brown, yellow, tan, and purple, fine to coarse, poorly to wellsorted sand. Pebbly layers are common, especially near the base. Clay clasts are fairly common, and clay layers ranging from 2 to 10 feet thick have been identified underlying the M-Area Settling Basin (SAIC, 1992). This unit is referred to as the "300-ft clay" by Eddy and others (1991). The screen zone for AMH-2 begins near the base of the Tobacco Road Formation then crosses down into the underlying Dry Branch Formation.

\subsection{4 "Upland Unit"}

The "Upland unit" unconformably overlies the Tobacco Road Formation. The South Carolina Geological Survey has been mapping it as the informally named "Upland unit" (Nystrom and Willoughby, 1982). It partially corresponds to sediments previously mapped at SRS as the Hawthorn Formation (Siple, 1967). The unit caps higher areas in much of the southwestern Coastal Plain of South Carolina and is a deposit of poorly-sorted, clayey, silty, pebbly, and cobbly quartz sand, conglomerate, and clay which show significant lateral and vertical variation.

In $\mathrm{A} / \mathrm{M}$ Area, these sediments are yellow, orange, purple, red, brown, and tan, mostly fine to very coarse, clayey, silty quartz sand beds. They are locally pebbly with layers of conglomerate and are very poorly to poorly sorted, moderately indurated. Weathered feldspar grains are abundant in places. Clay lenses interbedded with these sands are laterally discontinuous. Thickness of the "Upland unit" varies from 0 to approximately 60 feet. The sediments, which have low permeability, were probably deposited in high energy fluvial 
Summary Report of the Drilling Technologies Tested at the Integrated Demonstration Project for Cleanup of Organic Contaminants in Soils and Groundwater at Non-Arid Sites

channels, point bars, floodplains, and abandoned channels. The "Upland unit" has not been dated paleontologically, but it may correlate with the Miocene Altamaha Formation in Georgia (Nystrom et al., 1986).

Underlying the IDP site, the "Upland unit" is 50 feet thick at MHT-3C. Locally the "Upland unit" is characterized as a reddish orange, brown, and purple, poorly-sorted gravelly sand and clay. The sandy units have a speckled appearance (SAIC, 1992). The target zone for AMH-5 lies within the "Upland unit" and is referred to as the "325-ft clay" in this report. This unit also corresponds to the "325-ft clay" by Eddy and others (1991). The depth of this unit, at the AMH-5 drill site, is approximately 32 to 40 feet below land surface. It is characterized as a clayey sand, sandy clay, and clay with subordinate sand layers. Only a few clay layers exceed one foot in thickness. Textural evidence exists indicating that many of the one-foot intervals logged as clay and sandy clay, in the lower portions of this unit, are cobble to boulder-sized clasts of clay eroded from the underlying sediments or small lenticular clay lenses (SAIC, 1992).

Although the 325-ft clay has been placed in the lower portion of the "Upland unit" based on geophysical logs, the lithologic characteristics (pale purple, silty clay) are indicative of the underlying Tobacco Road Formation (personal communication with Andrew D. Smits, 1992). 
Summary Report of the Drilling Technologies Tested at the Integrated Demonstration Project for Cleanup of Organic Contaminants in Soil and Groundwater at Non-Arid Sites

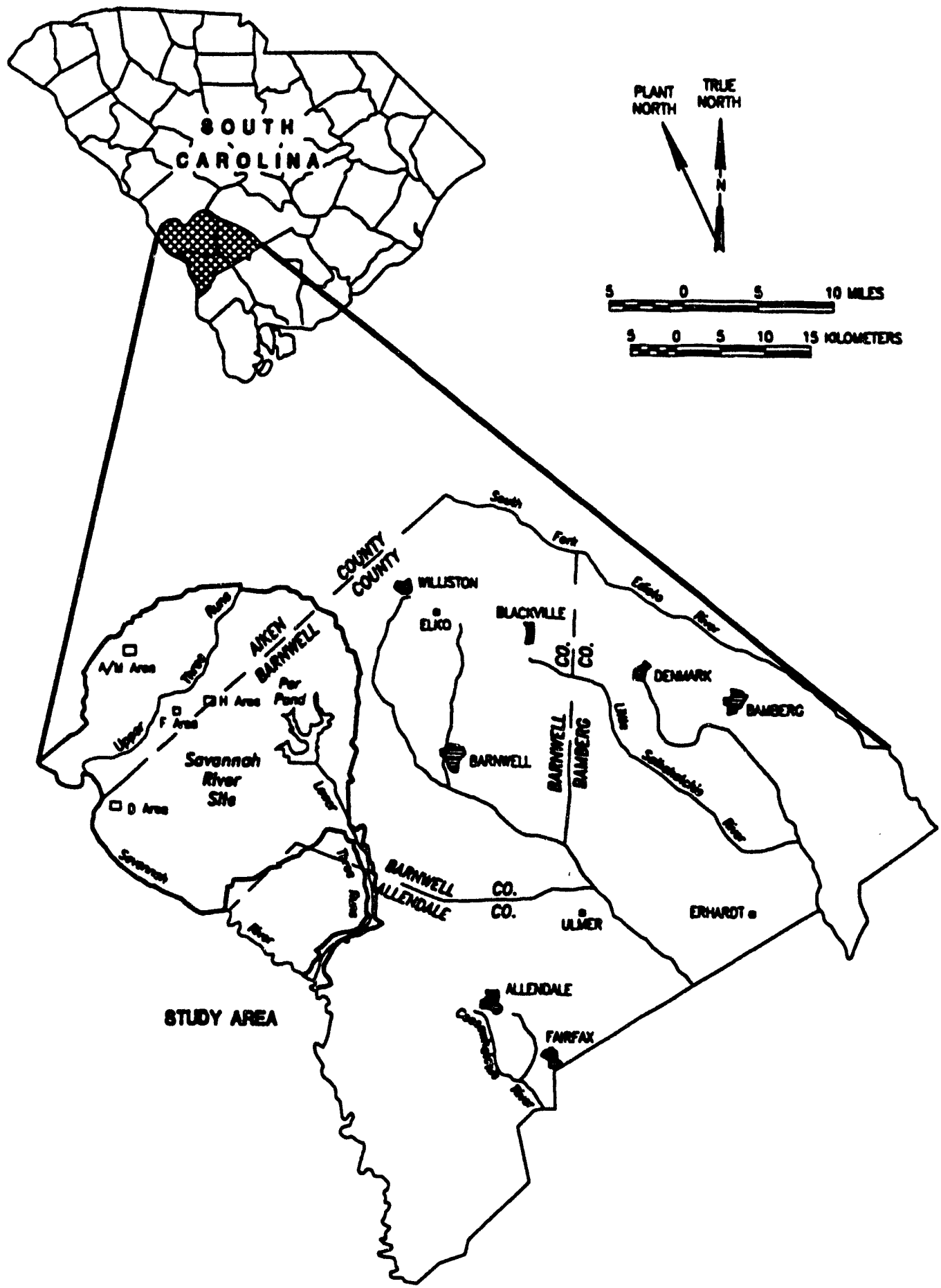

Figure 3.1 Location of the SRS in South Carolina 
Summary Report of the Drilling Technologies Tested at the Integrated Demonstration Project for Cleanup of Organic Contaminants in Soils and Groundwater at Non-Arid Sites

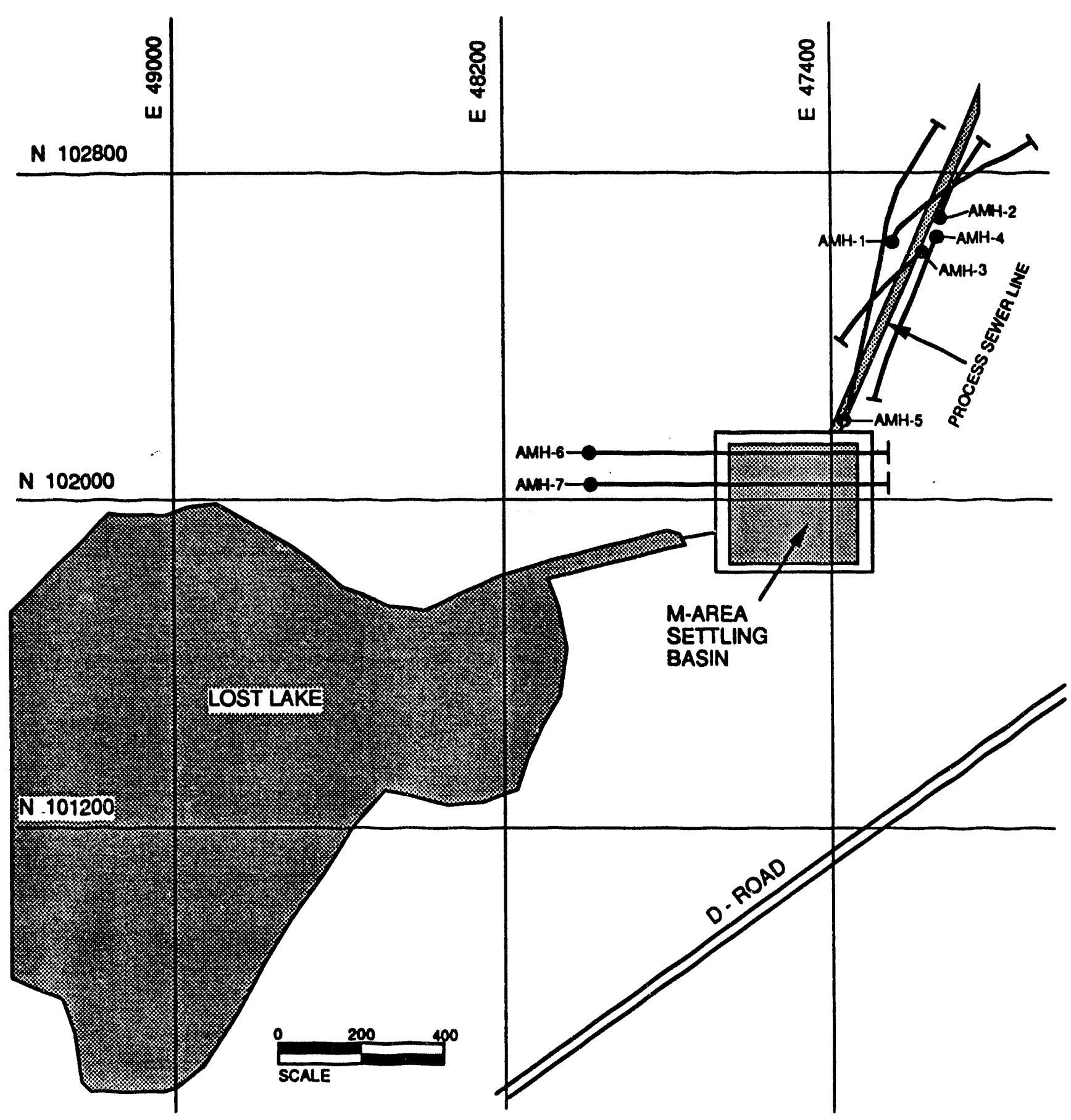

Figure 3.2 Location of M-Area Settling Basin

Hazardous Waste Management Facility 
Summary Report of the Drilling Technologies Tested at the Integrated Demonstration Project for Cleanup of Organic Contaminants in Soil and Groundwater at Non-Arid Sites

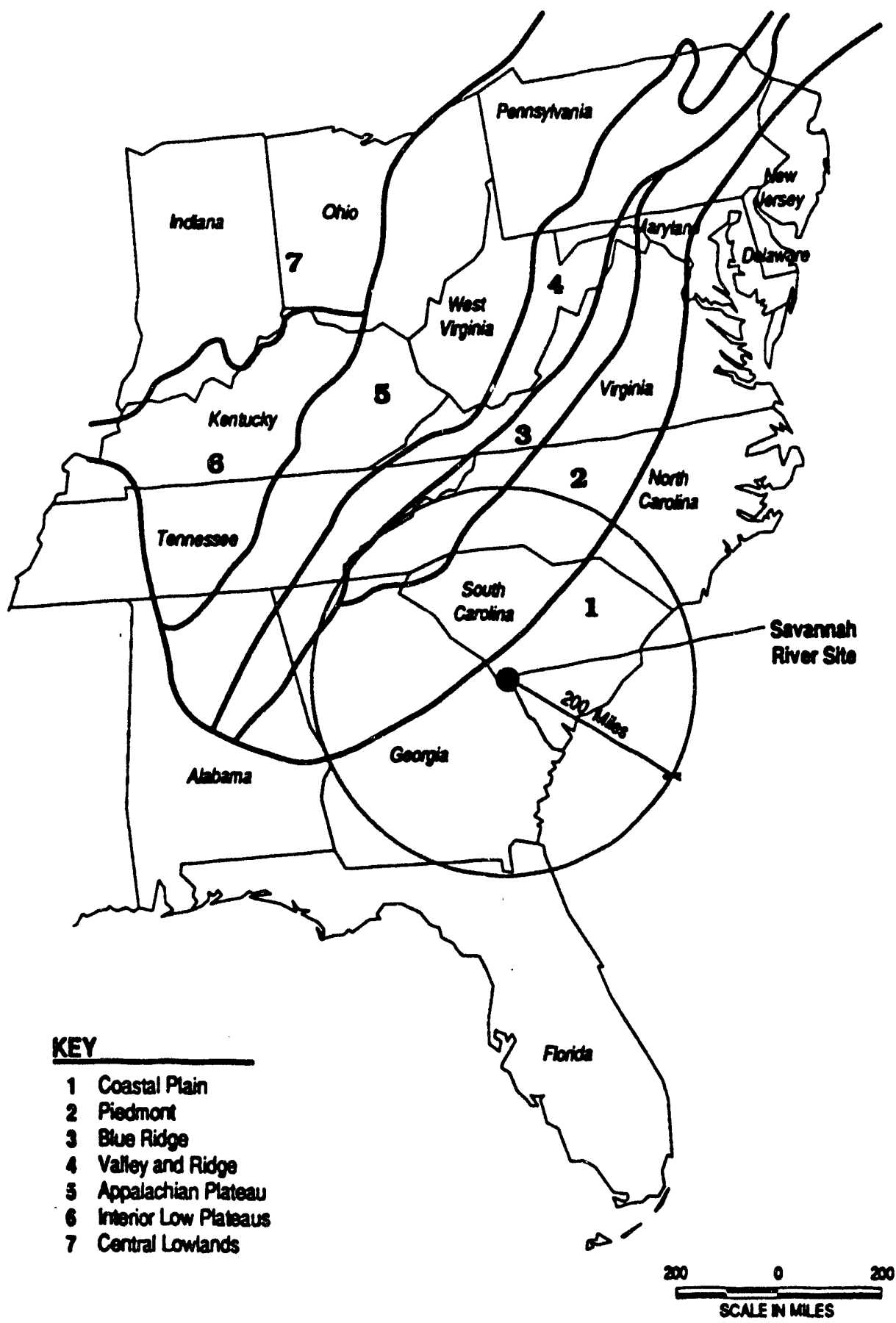

SOURCE: Wator Resources Commiesion Report, Number 155, 1909

Figure 3.3 Physiographic Provinces of the Eastern United States 
Summary Report of the Drilling Technologies Tested at the Integrated Demonstration Project for Cleanup of Organic Contaminants in Soils and Groundwater at Non-Arid Sites

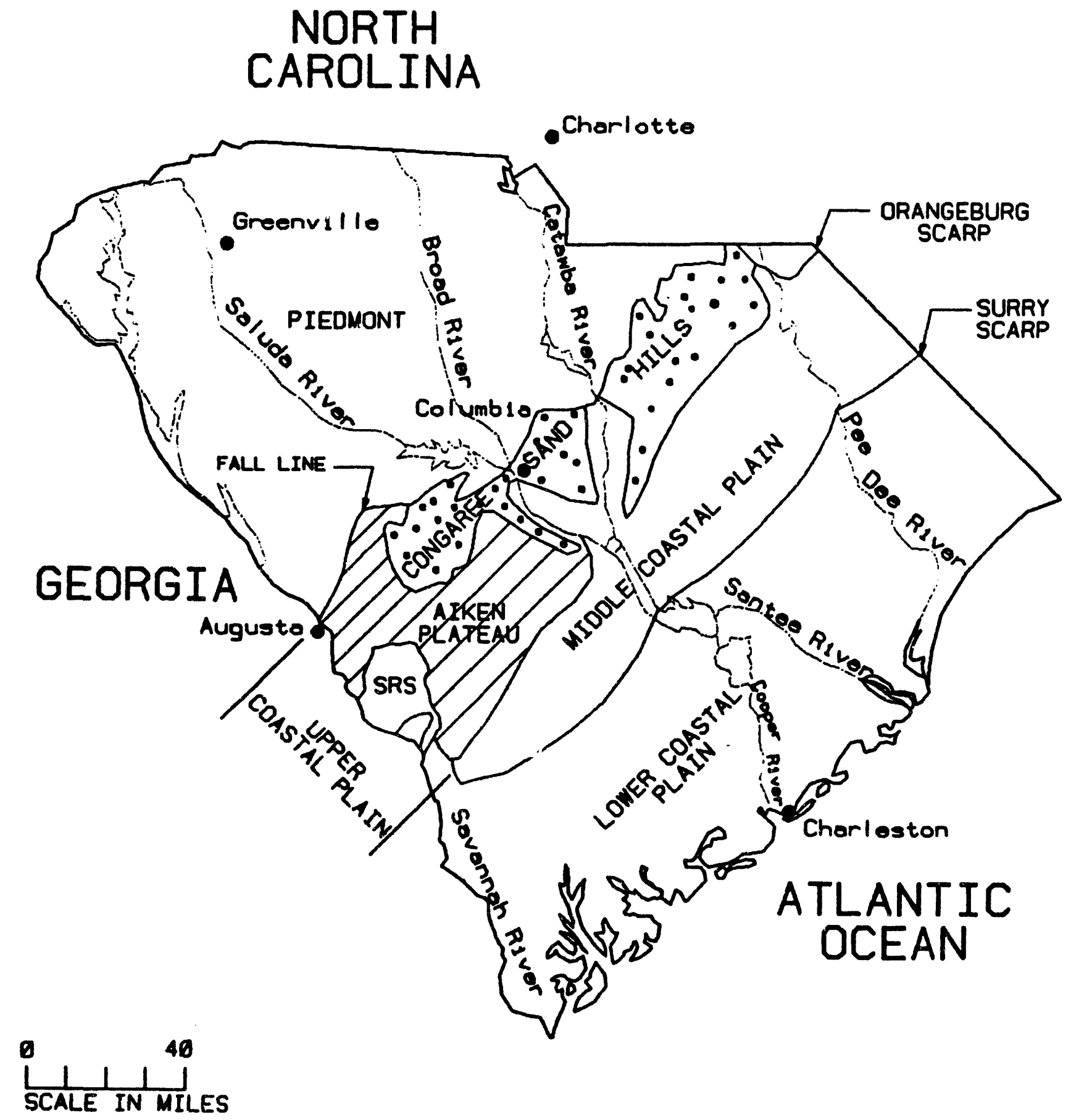

Figure 3.4 Physiographic Subprovinces of the Atlantic Coastal Plain 
Summary Repart of the Drilling Technologies Tested at the Integrated Demonstration Project for Cleanup of Organic Contaminants in Soil and Groundwater at Non-Arid Sites

\section{THIS PAGE LEFT INTENTIONALLY LEFT BLANK}


Summary Report of the Drilling Technologies Tested at the Integrated Demonstration Project for Cleanup of Organic Contaminants in Soils and Groundwater at Non-Arid Sites

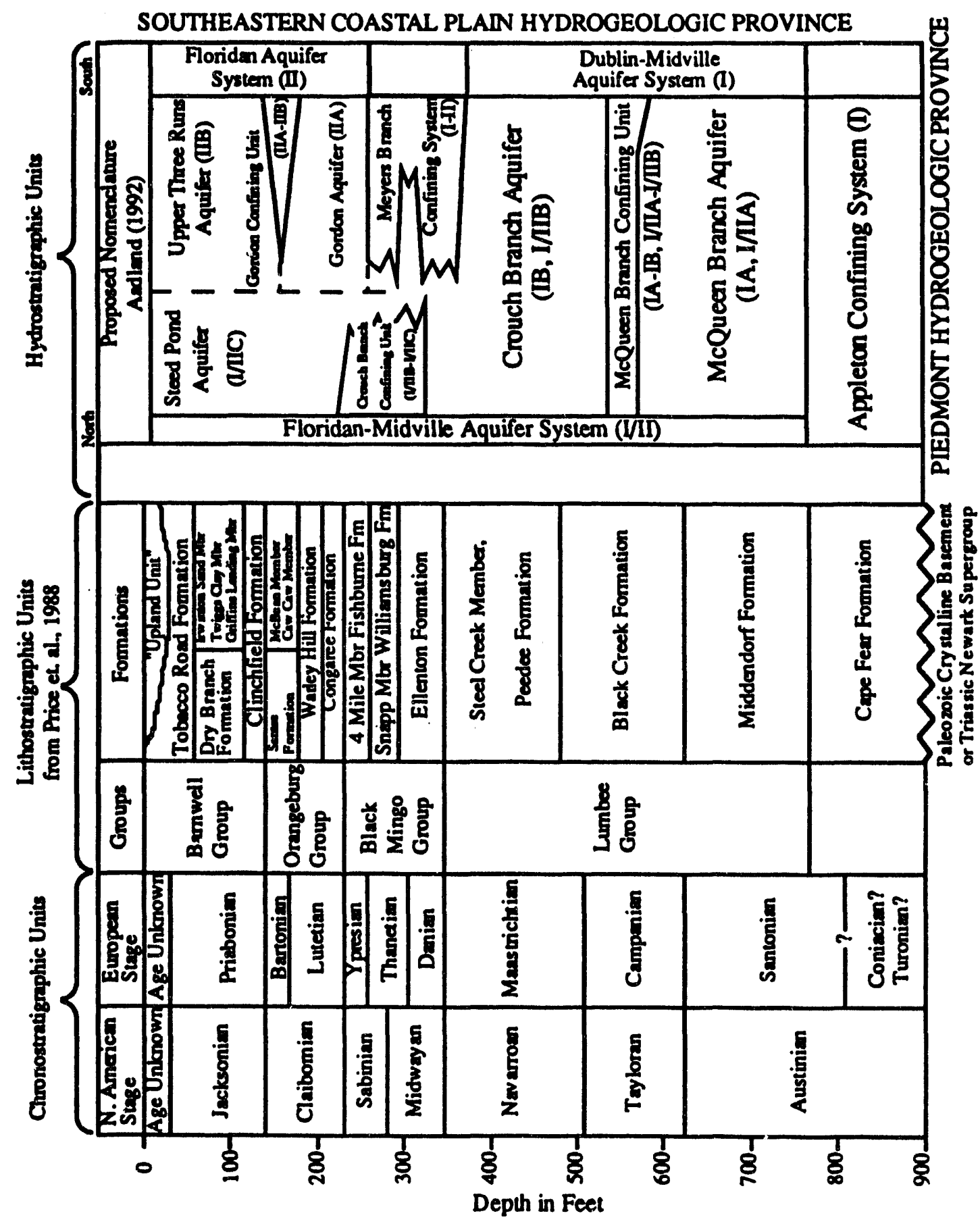

Figure 3.5 Comparison of Chronostratigraphic, Lithostratigraphic, and Hydrostratigraphic Units at the SRS 
Summary Report of the Drilling Technologies Tested at the Integrated Demonstration Project for Cleanup of Organic Contaminants in Soil and Groundwater at Non-Arid Sites

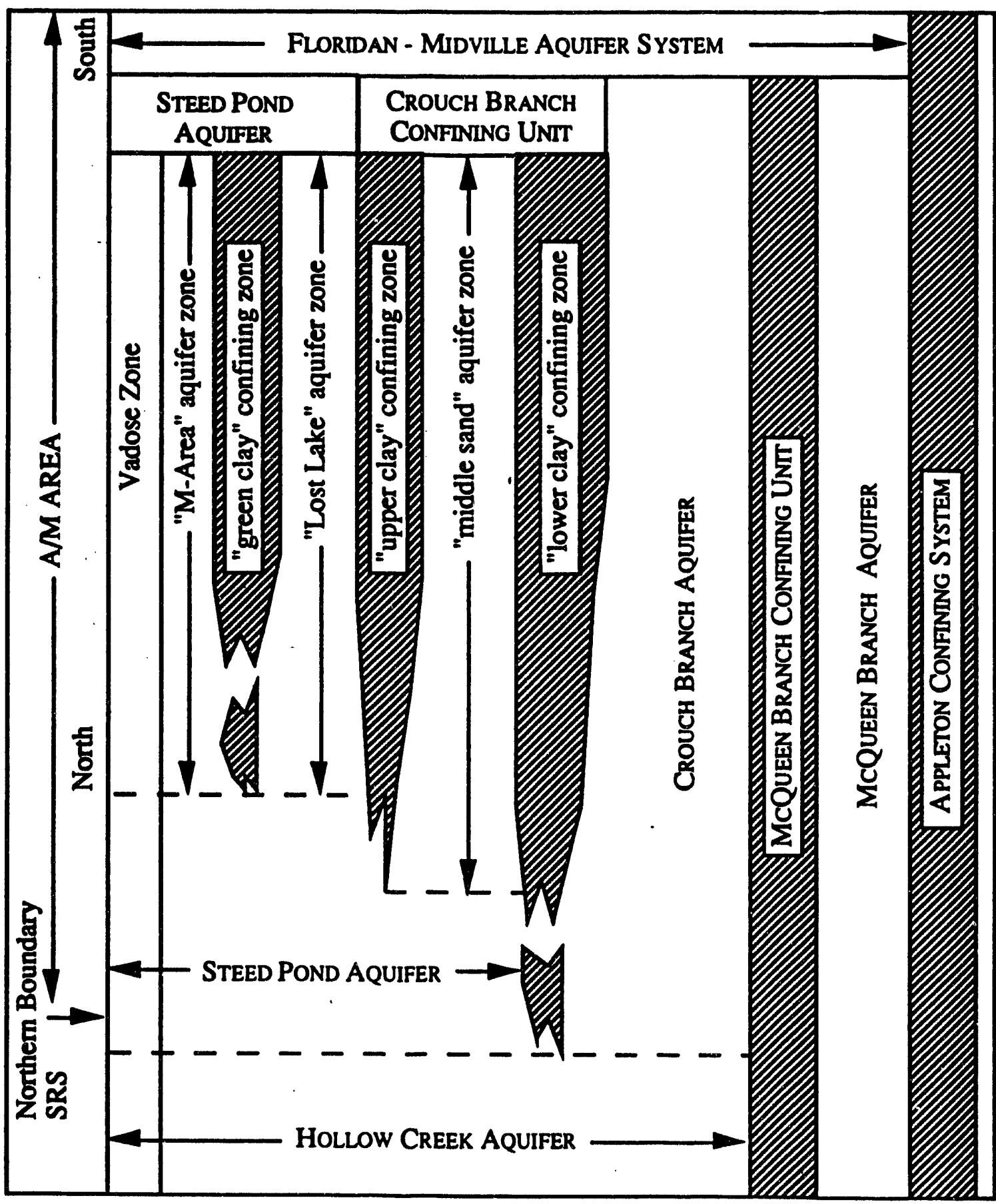

Figure 3.6 Hydrostratigraphic Chart for the A/M Area 
Summary Report of the Drilling Technologies Tested at the Integrated Demonstration Project for Cleanup of Organic Contaminants in Soils and Groundwater at Non-Arid Sites

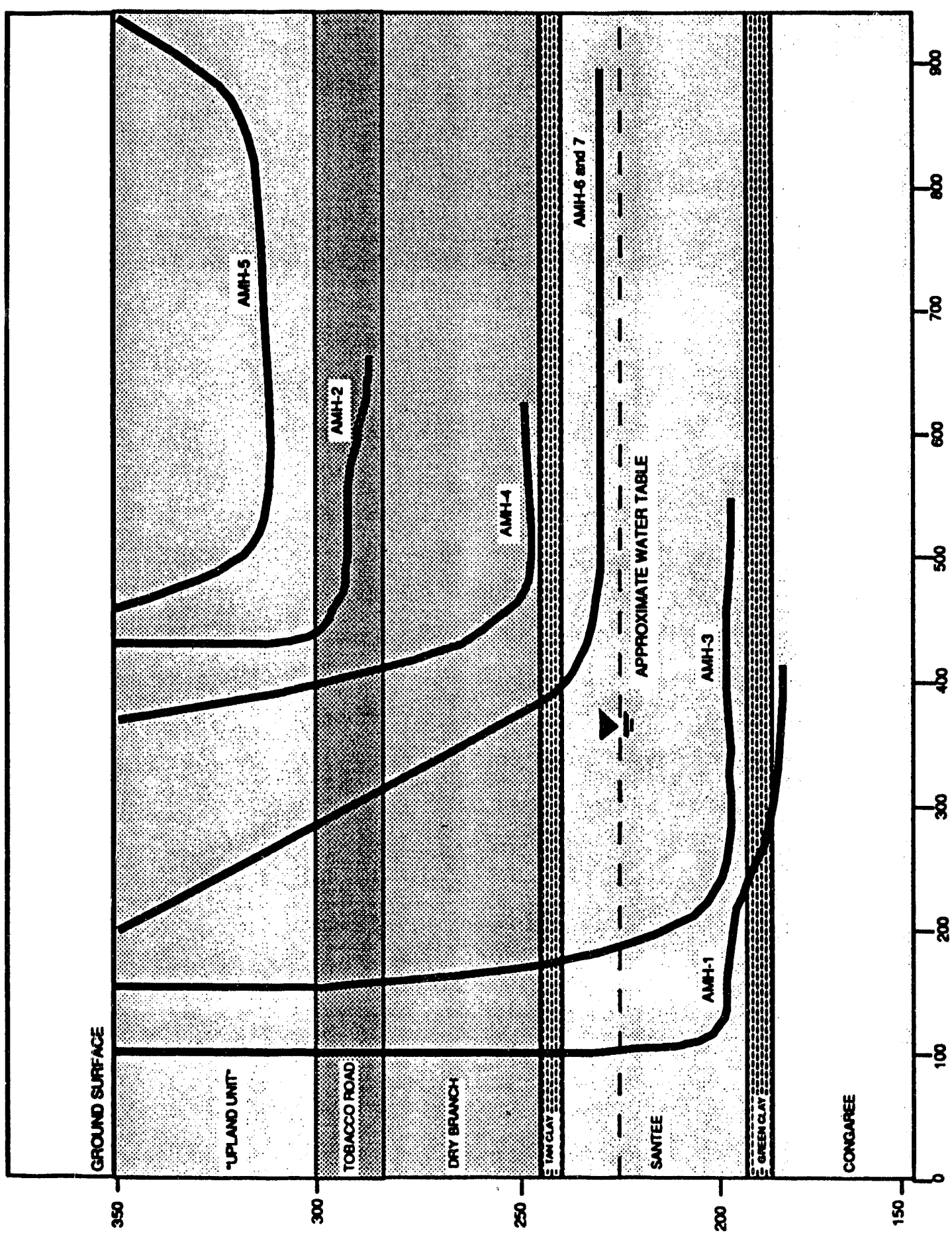

Figure 3.7 Schematic of M-Area Geology with Relative Locations of Horizontal Wells 
Summary Report of the Drilling Technologies Tested at the Integrated Demonstration Project for Cleanup of Organic Contaminants in Soil and Groundwater at Non-Arid Sites 


\subsection{DESCRIPTION OF DIRECTIONAL DRILLING SYSTEMS}

\subsection{General State Of The Horizontal Well Industry}

Horizontal environmental well technology is currently being developed from three established technological fields: the horizontal oil well technology field, the trenchless technology field, and the water well installation technology field. Not one of these technologies by itself offers all the solutions to the challenges of constructing horizontal environmental wells, but from this triad a new technology is emerging. Directional drilling techniques are being borrowed from both the petroleum and the trenchless technology industries, whereas well construction materials developed in the water resources industry are being modified to withstand the rigors of a horizontal installation.

Directional drilling has been used by several industries (petroleum, trenchless technology, and mining) for a number of years. The petroleum industry has used horizontal wells to improve petroleum recovery from low permeability or fractured reservoirs, and to provide multiple access points to a reservoir from a single offshore drilling and production platform. The first horizontal petroleum well drilled in the United States from a vertical borehole was completed in 1942. Directional drilling technology has significantly improved since that first well. Downhole mud motors and steering tools enable drillers to drill and install wells accurately in many different configurations. Directional drilling increased dramatically in the 1980s, and directional wells are now routinely considered as exploration and production wells.

Directional drilling in the trenchless technology industry, which adapted some directional drilling techniques from the petroleum industry, was initiated in the 1970 s to accommodate installation of pipelines and utilities beneath bodies of water, roads, subdivisions, and buildings without disturbing surface features. The trenchless technology industry grew as the drilling technology was refined and new markets, such as installations of fiber optic telecommunication systems and cable television, were developed.

The trenchless technology industry generally distinguishes drilling projects as either river crossing projects or utility installation projects. The differentiation is based on drilling 
Summary Repart of the Drilling Technologies Tested at the Integrated Demonstration Project for Cleanup of Organic Contaminants in Soil and Groundwater at Non-Arid Sites

techniques and equipment. In general, river crossing drilling projects require large drilling rigs, drilling fluid systems, sophisticated guidance systems, and specialty drill tools or downhole mud motors. River crossing drilling projects have included boreholes beneath most of the great rivers of North America, including the Mississippi River. River crossing boreholes have been as large as 60 inches in diameter, thousands of feet long, and pipes as large as $\mathbf{4 8}$ inches in diameter have been installed in the boreholes. Drilling companies that undertake river crossing drilling projects have often performed smaller utility installation projects.

Utility installations are usually performed with small to medium-sized drilling rigs, simplified drilling fluid systems (most often water or a dilute bentonite-based fluid is used), simple electronic beacon guidance tools, and simple drilling tools. There are many companies that specialize in the smaller scale utility installation projects.

The mining industry has also used directional drilling for many years. The most recent innovative use of directional drilling in the mining industry is for coal degasification applications. The boreholes are usually drilled from a vertical face in a mine.

The environmental industry began modifying directional drilling technology in 1988 to install horizontal extraction and injection remediation systems where it was not practical to excavate trenches. The first directionally drilled horizontal environmental wells were installed at the Department of Energy's Savannah River Site in 1988. Since that time horizontal environmental wells have been installed at several Department of Defense sites and various private industry sites. Directional drilling and horizontal well installation techniques are continually being modified to meet the requirements of the environmental industry.

Four directional drilling technologies were employed for the emplacement of horizontal environmental wells at the IDP site. Each of these technologies perform at various levels of effectiveness depending on varying geologic conditions, design parameters, and access limitations.

A total of seven horizontal environmental wells were installed at the IDP site. A short radius technology, adapted from the petroleum industry that relies on an in-hole whipstock and a 
Summary Report of the Drilling Technologies Tested at the Integrated Demonstration Project for Cleanup of Organic Contaminants in Soils and Groundwater at Non-Arid Sites

non-steerable drill bit to provide curvature from vertical to horizontal, was used to drill two horizontal wells. A modified petroleum industry technology that relies on a steerable mudmotor to drill directionally, was used to install two wells. A utility industry compactional drilling technology, using a wedge-shaped drill bit for drilling directionally, was used to install one well. A river crossing technology, using washover pipes emplaced over a directional drill string for screen installation, was used for the installation of two wells. Figure 4.1.1 outlines specific terminology and their formulas for calculations used for each of the drilling technologies listed below.

\subsection{Short Radius Drilling Technology}

The drilling and installation of the first two horizontal environmental wells, AMH-1 and AMH-2 was performed by ECEC and Graves Well Drilling of Jackson, South Carolina. These two wells were designed to be in the same vertical plane with the deeper water table well injecting air as a catalyst for liberating volatile organic compound (VOC) contaminants, and the shallower vadose zone well providing soil vapor extraction capabilities.

\subsubsection{Drilling Rig}

Due to the torque and power requirements for the directional drilling of these horizontal borings, a small petroleum exploration drilling rig was selected. The drilling rig was a DRILTECH DH-1 top drive hydraulic rotary rig, which supplied 475 horsepower and a maximum torque of 60,000 inch-pounds at 2,100 revolutions per minute (rpms).

\subsubsection{Down-Hole Drilling Assembly}

\section{Drilling Tool}

Directional drilling tools and directional drilling expertise were provided by ECEC. The A-tool short-radius system selected for this work included (1) a non-rotating curved drill guide, (2) flexible drive pipe, often referred to as "wiggly drill pipe", (3) an orientation assembly or 
Summary Report of the Drilling Technologies Tested at the Integrated Demonstration Project for Cleanup of Organic Contaminants in Soil and Groundwater at Non-Arid Sites

"whipstock", and (4) a stabilized straight-drilling assembly or rigid drill mandrel. Each of these components is described below.

\section{Curved Drill Guide}

The curve-drilling assembly is the heart of the short-radius rotary system. It deflects the borehole from the vertical to the horizontal. This curve-drilling assembly consists of two parts: the flexible drive pipe that ties the vertical string rotation to the curved drill guide and the curved drill guide itself. The curved drill guide, shown in Figure 4.2.1, is made of (1) a preshaped, flexible shell that gives curvature to the tool, (2) an internal drive shaft that imparts the rotation of the vertical string to the bit, and (3) two sets of bearing packs that connect the non-rotating shell and the internal drive shaft. The bearing packs allow the non-rotating flexible shell to carry the drilling thrust and allows the inner drive pipe to transmit rotational torque. The bit rotates without applying torque to the outer shell, thus allowing the assembly to remain positioned in the curve plane while drilling. Unique cuts on one side of the curved drill guide give the non-rotating shell the flexibility to traverse the vertical portion of the borehole and resume its curved shape when drilling the curve.

\section{Steering System}

The whipstock, shown on Figure 4.2.2, is essentially a steel pipe, open 180 degrees on one side with a beveled plate which helps the curved drill guide initiate its drilling of the curve. The portion of the whipstock where the curved drill guide first encounters the beveled plate is referred to as the kick-off point. This plate is slightly concave and acts to orient the direction of the curved drill guide as well as initiate the start of the curve.

During all phases of curve and lateral drilling, down-hole surveys are taken to record direction (azimuth) and angle (inclination) of the borehole, thus providing continuous monitoring of drilling performance and progress. Both single-shot and magnetic multi-shot survey tools were used. The single-shot survey tool is pumped down the drill pipe, records only the inclination of the borehole, and is retrieved by a thin wire to which it is attached. This tool provides a relatively quick means of monitoring drilling performance through the curve and lateral 
Summary Report of the Drilling Technologies Tested at the Integrated Demonstration Project for Cleanup of Organic Contaminants in Soils and Groundwater at Non-Arid Sites

portions of the borehole. The magnetic multi-shot survey requires removal of the drill string from the hole and attachment of the tool at the bottom of the drill sting in an aluminum housing, to avoid any magnetic interference from the steel drill string. Once lowered to the bottom of the hole, the tool records both inclination and azimuth every minute as the drill string is slowly pulled out of the hole. This produces regularly spaced survey data from which an accurate picture of the borehole can be created.

\subsubsection{Drill Rods}

\section{Elexible Drive Pipe}

The drive pipe, which is shown on Figures 4.2.1 and 4.2.3, is standard 4-1/2 inch full-hole modified-thread drill pipe which has cuts in a mushroom shape at one-foot intervals. The cuts give the drive pipe limited flexibility while allowing it to transmit large amounts of rotational torque, downward thrust and upward tensional force. Flexible, sealed inner liners allow the continuous circulation of drilling fluid to the bit.

\section{Rigid Drill Mandrel}

The stabilized straight-drilling assembly or rigid drill mandrel (Figure 4.2.3) maintains the inclination and direction reached at the end of the curve for the duration of the horizontal portion of the boring. The rigid drill mandrel consists of two near-bit, under-gauge stabilizers. By changing the bit angle with different stabilizer combinations, angle-hold, slight angle-build or slight angle-drop of the lateral path can be accomplished.

\subsubsection{Drilling Fluid System}

The drilling fluid system was a crucial part of drilling and well installation, providing efficient removal of drill cuttings and adequate hole stability. Borehole stability was essential for maintaining the integrity of the curve and the lateral portions of the borehole in the soft sediments. D \& M Drilling Fluids, of Jay Florida, managed the drilling mud system for the project. 
Solids control, the removal of drill cuttings from the drilling fluid, was achieved by using a plastic-lined settling pit followed by a multi-cone hydrocyclone de-silter and a vibratory screen de-sander. All drilling fluid additives were mixed in sectioned steel mud tanks. Mud was circulated down the holes using a Gardner-Denver type, FX-Duplex pump with four 5-inch pistons and a 6-inch stroke. This pump delivers a maximum flow of 150 gallons per minute (gpm) and a maximum pressure of 310 pounds per square inch (psi).

The mud program was modified during the course of the project to improve hole stability, fluid loss control, and overall drilling performance as more was learned about how the sediments reacted to horizontal drilling. The original drilling fluid program called for the lateral drilling to be performed with a bentonite-polymer-freshwater system, which consisted of the following constituents:

- non-peptized bentonite gel

- partially hydrolyzed polyacrylamide ([PHPA], i.e. EZ Mud ${ }^{T M}$ or Quick-Trol ${ }^{\mathrm{TM}}$ ) for greater viscosity and enhanced filtercake formation

- sized calcium carbonate (sized 5,50,150, and 600) to increase fluid weight for greater hole stability and to provide bridging material for decreased fluid loss to the formation

- fresh water.

These constituents were mixed as 23.8 pounds of bentonite and 208 pounds of calcium carbonate to 100 gallons of water with polymer added as needed to maintain adequate viscosity and filter-cake formation. This drilling fluid possessed the following fluid characteristics:

- moderate to high solids ( $4 \%$ to $10 \%$ by volume)

- relatively high weight (8.9 to 10.1 pounds/gallon)

- moderate to high viscosity (funned viscosity 40 to 150 seconds)

- high yield point (15 to 65 pounds/100 feet squared)

Because complications arose during the drilling and completion of well AMH-1, the drilling fluid program was modified by the project mud engineer. The drilling fluid was modified to a 
Summary Report of the Drilling Technologies Tested at the Integrated Demonstration Project for Cleanup of Organic Contaminants in Soils and Groundwater at Non-Arid Sites

bentonite-polymer-lignosulfonate-water based system with drilling soap and bentonite extender for better fluid characteristics. This system consisted of the following constituents:

- non-peptized bentonite gel for viscosity

- bentonite extender (Ben-Ex ${ }^{T M}$ ) to prolong bentonite gel life

- drilling soap for lubricity

- inorganic polymers (Baroid Quick-Trol ${ }^{\mathrm{TM}}$ and $\mathrm{E}-\mathrm{Z} \mathrm{Mud}^{\mathrm{TM}}$ ) for greater viscosity with minimal fluid-weight increase and stronger filtercake formation

- lignosulfonate, for enhanced filtercake formation.

These constituents were mixed in varying proportions in order to maintain the following fluid properties:

- low solids ( $2 \%$ to $4 \%$ by volume)

- low weight (8.6 to 9.0 pounds/gallon)

- moderate viscosity (funnel viscosity 38 to 45 seconds)

- fairly high yield point (15 to 25 pounds/feet squared)

- high lubricity for improved fluidflow characteristics.

Performance of these drilling fluids is discussed in Section 5.0.

\subsubsection{Well Materials and Installation}

The air-injection or water table well, AMH-1, was installed at 154 feet below ground level. Well materials for AMH-1 consisted of 2-3/8-inch tubing, perforated with 1/8-inch diameter holes. The desired length of tubing needed for the screen (309.71 feet) was perforated with 5 pairs of 1/8-inch holes per 20-foot section before installation. The holes were drilled in pairs on opposite sides of the tubing. Each pair was rotated $90^{\circ}$ from each other. The perforated tubing was installed in the lateral portion of the borehole. Then, 121.77 feet of non-perforated 2-3/8-inch tubing and an inflatable casing packer were installed above the perforated tubing. Approximately 7.0 feet of casing were attached to the top of the packer to bring the casing to the surface. The horizontal well construction diagram for AMH-1 is presented in Figure 4.2.4. 
The extraction or Vadose zone well, AMH-2, was installed at 75 feet below ground level. Well materials consisted of 4-1/2-inch diameter stainless-steel wire-wrapped screen with 0.010-inch slots. Screen was installed through the curved portion of the borehole because of the limited flexibility of the casing packers. Two cement baskets, instead of casing packers, were attached to the casing above the screen, attached near the center of 21.1 feet of 4-1/2-inch stainless-steel casing. The cement baskets were attached at 11.4 and 13.9 feet below the top of the casing. A total of 204.7 feet of 4-1/2-inch diameter stainless-steel wire-wrapped screen with 0.010-inch slots and 21.1 feet of 4-1/2-inch diameter steel casing were installed in AMH-2. The horizontal well construction diagram for AMH-2 is presented in Figure 4.2.5.

\subsection{Modified Petroleum Industry Drilling Technology}

ECES drilled and installed horizontal environmental wells AMH-3 and AMH-4. ECES developed a specialized drilling rig to provide the torque and power requirements for the directional drilling of these types of horizontal borings. Similar to the emplacement of AMH-1 and AMH-2, one of these wells was designed as a water table well for the vaporization of VOCs and the Vadose zone well was for soil vapor extraction.

\subsubsection{Drilling Rig}

The drilling rig used was a DRECO ${ }^{\mathrm{M}}$ slant-hole custom-designed mud-rotary drilling rig. This rig generates a maximum of 500-horsepower with a maximum rig torque rating of 10,000 foot/pounds for the casing drive at $160 \mathrm{rpms}$.

\subsubsection{Down-Hole Drilling Assembly}

The direction and orientation of the curve and lateral sections of the borehole were controlled by the non-magnetic bottom hole assembly (BHA), which consisted of an expandable wing drill bit or underreamer, a steerable down-hole motor (DHM), a tool face indicator (TFI), and casing attachments. Each of these components was connected by knuckle-joints, which allowed the BHA to form a three-point geometry. The knuckle-joints allowed each tool to be 
Summary Report of the Drilling Technologies Tested at the Integrated Demonstration Project for Cleanup of Organic Contaminants in Soils and Groundwater at Non-Arid Sites

set at an angle to each other, creating an arc composed of the bit, DHM, and TFI. A conceptual schematic of the BHA is illustrated in Figure 4.3.1.

\section{Drilling Tool}

Drilling was accomplished using the DHM. Drilling fluid pressure provided the hydraulic driving force necessary for the DHM to rotate the drill bit and cut through the sediments. Flow rates from 150 to $300 \mathrm{gpm}$ generated from 18 to 40 horsepower at the bit. The DHM had eccentric stabilizers which were used to create off-set between the bit and the TFI, creating an are which determined the radius of curvature. Figure 4.3.2 presents a more detailed illustration of the steerable DHM.

\section{Steering System}

The TFI measured the orientation of the tool in relation to its position in the casing and the inclination (measured from horizontal in the lateral section and vertical in the curved section) of the drill bit at that point. During the drilling of the curved and horizontal sections of the boreholes, the drilling engineers monitored TFI data sent by impulse through the drilling fluid to a recorder on the drilling platform. The TFI provided inclination and tool face orientation only. The TFI was located approximately 15 feet behind the drill bit so direction and measured depth were extrapolated geometrically to the bit using location data received from the TFI.

The BHA was seated inside a 10-inch inside diameter high density polyethylene (HDPE) casing and steel shoe. The BHA could be extended as far as drilling conditions would allow; however, the retraction of the BHA was limited to approximately 1 -foot by a shoulder inside the shoe. This shoe prevented the casing from sliding over the bit. The stabilizers were set prior to drilling the curve and then re-set prior to drilling the lateral section.

Downhole surveys were performed on a regular basis as the curved and horizontal sections of the boreholes were being drilled. Two survey methods employing different down-hole tools were used during drilling. Off bottom single-shot surveys measured the azimuth and inclination of the drill rod in the borehole at a point. This was used periodically during drilling 
Summary Report of the Drilling Technologies Tested at the Integrated Demonstration Project for Cleanup of Organic Contaminants in Soil and Groundwater at Non-Arid Sites

to verify the TFI readings coming from the DHM. Upon completion of each curved and horizontal section, magnetic multi-shot surveys were performed that measured the same parameters as the single-shot, but in specific incremental lengths throughout the entire length of the borehole.

\subsubsection{Drill Rods}

Each borchole was drilled in three segments: (1) from land surface to the kick-off point (KOP), (2) the curved portion from the KOP to the end of curve (EOC), and (3) the horizontal section. Figure 4.3.3 illustrates the location of each segment relative to one another and the associated terminology. The angled portion of each boring to KOP was augered using solidstem augers. The boreholes were then cased with 14-inch OD steel conductor pipe with a flanged joint at the top end. A bell nipple was bolted to the flange joint. The bell nipple was used to direct drilling fluid and serve as a housing for material and tool installation. The casing was pressure grouted in place with neat cement grout containing calcium chloride $\left(\mathrm{CaCl}_{2}\right)$ and bentonite.

After allowing the grout to cure, a tri-cone roller bit was used to drill out the grout seal at the bottom of the surface casing (conductor pipe). Mud rotary drilling methods were used from this point on. Subsequent to drilling out the grout seal at the base of the surface casing, the TFI and DHM were assembled and attached to a collapsible 10-inch diameter wing-bit. The TFI was calibrated and tested at land surface prior to insertion into the borehole. Eccentric stabilizers were set to define the off-set of the bit. The off-set was such that when the BHA was assembled, the steerable motor would lie on a flat surface, and the bit and TFI would be raised at an angle off the surface. That is, the centerline through all three components of the BHA would not be straight, or parallel to the steerable motor. Drilling of the curve section of the boreholes required advancing the BHA and the attached 10-inch inside diameter (ID) HDPE casing through the 110-foot radius curve.

The hydraulic pressure of the drilling fluid expanded wings on the drill bit cutting a hole with sufficient diameter to permit a 10-inch or 6-inch diameter casing to be installed behind the drill bit. The casing was attached to the DHM behind the last eccentric stabilizer. The wings were 
Summary Report of the Drilling Technologies Tested at the Integrated Demonstration Project for Cleanup of Organic Contaminants in Soils and Groundwater at Non-Arid Sites

expanded by a piston driven by drilling fluid pressure. The wings were retracted by venting drilling fluid pressure from the surface, allowing the wings to collapse into the bit housing. The bit was then pulled out of the borehole through the casing.

The horizontal section of the borehole was advanced utilizing the BHA assembly equipped with an 8-5/8-inch diameter wing-bit. Drilling of the horizontal sections of the boreholes required drilling a series of concave and convex arcs to form the lateral section. The BHA was initially assembled with a length and curvature that defined a predetermined radial curve. The tool bit was then rotated in the casing at calculated intervals to drill up or down. This alternating drilling orientation created a series of concave and convex arcs, that, overall, defined a horizontal trend. Slotted, 6-inch diameter HDPE well casing was secured to the backside of the DHM and advanced with the BHA. The direction and angle were maintained in the same manner as for the curved section, except angles were maintained close to $90^{\circ}$ from vertical and directions near $S 10^{\circ} \mathrm{E}\left( \pm 10^{\circ}\right)$.

\subsubsection{Drilling Fluid System}

The drilling fluid system was a critical part of drilling and well installation, providing efficient removal of drill cuttings from the borehole, maintaining adequate flow in the annular space to reduce casing skin friction, and providing adequate borehole stability. The drilling fluid was pumped through the drill rods (inside the casing) and recirculated through the annulus to the surface with a hydraulic 325-horsepower mud pump. The mud pump used was a three piston pump with a maximum flow rate of 350 gallons per minute (gpm) and a maximum pump pressure of 1200 psi.

The functions of the drilling fluid were to open and close the bit, lubricate the bit, and remove cuttings from the borehole. The drilling fluid may lubricate installation of the casing/screen assembly somewhat, advancing the assembly behind the drill bit is the primary mechanism of assembly placement. Accordingly, the most important purpose of the mud program was to carry cuttings from the bit out of the borehole. 
Summary Report of the Drilling Technologies Tested at the Integrated Demonstration Project for Cleanup of Organic Contaminants in Soil and Groundwater at Non-Arid Sites

The drilling fluid used during the early course of the project was primarily bentonite powder mixed with water. The viscosity, as measured with a Marsh funnel, was monitored periodically and maintained at a range of 30 to 50 seconds. The weight of the mud at that viscosity was approximately 8 to 9 pounds per gallon (lbs/gal). As drilling progressed in each attempt, sloughing of the borehole impeded the progress of well installation. Delays due to rig and survey tool performance also contributed to borehole instability which resulted in sloughing. The drilling fluid program was modified after all efforts to improve drilling and downhole survey tool performance failed to overcome the geologic conditions. A Milkem ${ }^{\text {TM }}$ mud engineer was subcontracted to modify the drilling fluid program which included the use of bentonite extenders and polymers.

The modified mud program improved hole stability, controlled fluid loss, and improved overall drilling performance. The fluid characteristics used for successful completion of both wells included the following:

- low weight (8.6 to $9.0 \mathrm{lbs} / \mathrm{gal})$

- high viscosity (Marsh funnel viscosity of 95 to 105 seconds)

- high lubricity (utilizing polymers).

The preferred drilling fluid with the above properties consisted of a fresh-water based system with the following constituents:

- non-peptized bentonite gel for viscosity

- bentonite extender (Ben-Ex ${ }^{\mathrm{TM}}$ ) to prolong bentonite gel life

- powdered polymers (New-Drill ${ }^{\mathrm{TM}}$ ) for greater viscosity with minimal fluid weight increase and stronger filter cake formation.

\subsubsection{Well Materials and Installation}

The injection or water table well, AMH-3, was installed at 151 feet below ground level. The well materials consisted of 6-inch diameter HDPE screen (slot size unspecified), 10-inch diameter HDPE casing, and 14-inch diameter steel conductor pipe for surface casing. The 
Summary Report of the Drilling Technologies Tested at the Integrated Demonstration Project for Cleanup of Organic Contaminants in Soils and Groundwater at Non-Arid Sites

6-inch screen extended from the KOP to the end of the borehole (488 feet measured depth [MD]) and was packed with a natural sand pack from the end of the curved section (EOC), approximately 230 feet MD, to the end of the borehole. The 10-inch diameter HDPE casing extended to the EOC. HDPE filter beads were installed in the annulus of the 10-inch HDPE casing from the KOP to the EOC. The 14-inch steel casing was installed from ground surface to 20 feet below ground surface. The horizontal well construction diagram for AMH-3 is presented in Figure 4.3.4.

The extraction or vadose zone well, AMH-4, was installed at 101 feet below ground level. The well materials consisted of 6-inch diameter HDPE screen (slot size unspecified), 10-inch diameter HDPE casing, and 14-inch diameter steel conductor pipe for surface casing. The 6-inch screen extended from three feet below ground surface to the end of the borehole (300 feet $M D$ ) and was packed with a natural sand pack from just above the KOP, approximately 46 feet MD, to the end of the borehole. The 10-inch diameter HDPE casing extended to the EOC, approximately 148 feet MD. HDPE filter beads were installed in the annulus of the 10-inch HDPE casing from the KOP to the surface. The 14-inch steel casing was installed from ground surface to 20 feet below ground surface. The horizontal well construction diagram for $\mathrm{AMH}-4$ is presented in Figure 4.3.5.

\subsection{Utility Industry Compactional Drilling Technology}

The drilling and installation of AMH-5 was performed by Charles Machine Works (Ditch Witch $\left.{ }^{(}\right)$of Perry, Oklahoma. The well was designed to test the ability of utility industry technology to install horizontal wells in unconsolidated sediments and semi-consolidated clay units. The well was also installed to test the effectiveness of radio frequency (RF) heating combined with soil vapor extraction.

\subsubsection{Drilling Rig}

An experimental drilling rig (Fig. 4.4.1) with a patented directional drilling tool was used during the project. The drilling rig, designated $X-810$, is a top drive hydraulic rotary rig with an $\mathbf{8 0}$ horsepower motor pack and high thrust and rotational torque capacity. 
Summary Report of the Drilling Technologies Tested at the Integrated Demonstration Project for Cleanup of Organic Contaminants in Soil and Groundwater at Non-Arid Sites

\subsubsection{Down-Hole Drilling Assembly}

The down-hole assembly consists of the directional drilling tool, the steering tool contained in a housing, and a flexible sub-assembly (Fig. 4.4.2). The total length of the down-hole assembly is approximately 5 feet. All components of the down-hole assembly, including the closest three pieces of drill stem, are constructed of non-magnetic steel to prevent magnetic interferences with the steering tool.

\section{Drilling Tool}

The patented directional drilling tool was supplied by Ditch Witch ${ }^{\otimes}$ (Fig. 4.4.3). The tool is wedge shaped, approximately 15 inches long, 6 inches wide, and hexagonal in cross-section. Carbide cutting pieces are located at the top and base of the wedge. An initial test of the tool during the drilling program led to the addition of carbide cutting pieces to the side edges of the wedge or tool face. The wedge-shaped tool face provides the impetus for the drilling tool to deviate from a linear path in order to drill the curved sections of the borehole. When the drilling tool is pushed forward without rotation, the tool deviates in the direction of the slant of the tool face. To drill without deviation the drilling tool is rotated as it is pushed forward; in this way the tool face does not have a preferred orientation, and the drilling tool advances along a straight path, as in the slant or horizontal sections of the borehole. The tool face orientation is monitored by the steering system.

\section{Steering System}

The steering system (located just behind the drilling tool) was supplied by SNL and is commercially available from Survey Technology of Santa Ana, California under the trade name of Drill Scout ${ }^{\mathrm{TM}}$. The down-hole steering tool weighs 22 pounds (lb), is 20 inches, long and 1.625 inches in diameter. The steering tool monitors drilling tool face orientation (roll) from $0^{\circ}$ to $360^{\circ}$ in $5^{\circ}$ increments, uses a magnetometer to determine azimuth (magnetic heading) from $0^{\circ}$ to $360^{\circ}$ in $1^{\circ}$ increments, and has an accelerometer to determine inclination $\left( \pm 30.0^{\circ}\right.$ from horizontal). The azimuth measurements of the steering tool are sensitive to the tool's orientation in the earth's magnetic field. The tool is less accurate when taking azimuth 
Summary Report of the Drilling Technologies Tested at the Integrated Demonstration Project for Cleanup of Organic Contaminants in Soils and Groundwater at Non-Arid Sites

measurements when it is oriented parallel to the earth's magnetic field than when the tool is oriented perpendicular to the earth's magnetic field. The down-hole tool receives power from, and sends information to, a surface control unit through a standard wireline. The surface control unit displays tool face orientation, azimuth, and inclination readings. Knowledge of the tool face orientation allows the driller to control the borehole deviation. Knowledge of the MD of the drill stem, the azimuth along the borehole, and inclination along the borehole allows the driller to accurately locate the drilling tool in the subsurface.

\subsubsection{Drill Rods}

As stated previously, the drill bit was wedge shaped. Two initial attempts were made to drill the boreholes; however, these attempts were unsuccessful in penetrating the clay strata encountered. The wedged-shaped drill bit was modified by attaching carbide cutters to both sides of the bit as well as attaching larger carbide cutters to the base of the bit. This bit was advanced into one of the holes drilled in the previous attempts, so the new bit was never tested in the rotating mode. However, the bit was significantly more aggressive than the previous bits.

\subsubsection{Drilling Fluid System}

The patented directional drilling tool was designed to drill with or without drilling fluids. Drilling boreholes with this drilling tool offers an advantage because drilling fluids may not be required. All other existing directional drilling techniques require a drilling fluid to maintain borehole stability and to remove drill cuttings from the borehole. When drilling through contaminated areas, the drilling fluid becomes contaminated; therefore, the fluid requires the same costly handling and disposal costs as contaminated drill cuttings. Compaction drilling maintains borehole stability by compacting drill cuttings into the borehole sidewall; therefore, no cuttings are created and the borehole remains stable.

The one disadvantage to the compaction drilling method is the resulting skin damage done to the borehole side wall. The skin damage is a compacted, decreased permeability zone immediately adjacent to the borehole. 
Sumnary Report of the Drilling Technologies Tested at the Integrated Demonstration Project for Cleanup of Organic Contaminants in Soil and Groundwater at Non-Arid Sites

The X-810 experimental drilling rig is capable of advancing a borehole with or without the use of drilling fluid. During this project, water was used as a drilling fluid to lubricate the drilling tool, cool the steering tool, and to lubricate the borehole. The drilling fluid system consisted of a water reservoir, a water pump, and a delivery system. Water was pumped at a flow rate of 1 to 3 gallons per minute (gpm) at 350 to 450 pounds psi. The drilling fluid never returned to the surface and is assumed to have been lost to the formation; a total of 1500 to 2000 gallons of water is estimated to have been used in drilling the borehole.

\subsubsection{Well Materials and Installation}

The well string for AMH-5 consisted of:

- 150 feet of 3.5-inch outside diameter fiberglass entry riser well casing.

- 300 feet of 3.5-inch OD 0.010 slotted fiberglass well screen.

- 137 feet of 3.5-inch OD fiberglass exit riser well casing.

Approximately 10 feet of well casing was left above ground level at both the entrance and exit holes. The well was packed with a natural sand pack to the surface. Concrete pads, constructed at both the entrance and exit holes, are the only seals associated with the well installation. The horizontal well construction diagram for AMH-5 is presented in Figure 4.4.4.

\subsection{River Crossing Industry Drilling Technology}

A river crossing industry directional drilling rig was used for the installation of AMH-6 and AMH-7. These two wells were installed parallel to each other, under the M-Area Seepage Basin, for use in vapor extraction of contaminants. River crossing industry directional drilling rigs range in size from small trailer mounted drilling rigs that can be pulled by a pick-up truck to large semi-tractor trailer mounted drilling rigs capable of drilling large (up to 60-inches in diameter) boreholes thousands of feet. Horizontal wells AMH-6 and AMH-7 were installed using a medium-sized river crossing directional drilling rig. 
Summary Report of the Drilling Technologies Tested at the Integrated Demonstration Project for Cleanup of Organic Contaminants in Soils and Groundwater at Non-Arid Sites

\subsubsection{Drilling Rig}

The MC-90 drilling rig (Fig. 4.5.1) is a top drive hydraulic mud rotary rig with a high thrust and rotational torque capacity. The maximum thrust power of the drilling rig is 47,000 pounds (lbs). The maximum pullback capacity is $120,000 \mathrm{lbs}$. The maximum spindle rotational speed of the drilling rig is $200 \mathrm{rpms}$ with a maximum spindle torque of 6,000 foot-pounds. The maximum mud pressure of the power source is 2500 psi generated from 234 horsepower. The drilling rig is able to turn drill pipe in sizes ranging from the smallest available size up to 12 inches in diameter for distances of up to 2,000 feet in most soil conditions. The diameter and/or length capability may be significantly reduced where formations contain 30 percent or more gravels. The maximum drill rod length for the drilling rig is 10 feet. The drilling operations are controlled from a console mounted on the right side of the drilling rig.

The drilling rig is track driven and has two adjustable drilling platforms that allow the driller to accurately adjust the drilling angle. The track drive and the drilling platform are controlled from a console located at the rear of the drilling rig. The approximate operating weight of the rig is $8,000 \mathrm{lbs}$.

At the front of the drilling rig there is a piston-driven ram that is used to anchor the drilling rig. The drilling rig anchor is created by welding the ram to a mass of metal buried in the ground (a "dead man"). During this project the "dead man" anchor consisted of two 10-foot sections of 4- inch drill pipe driven vertically into the ground.

\subsubsection{Down-Hole Drilling Assembly}

The down-hole drilling assembly consists of a directional drilling tool and a steering tool contained in a non-magnetic housing (Fig. 4.5.2). The total length of the down-hole drilling assembly is approximately 15 feet. All components of the down-hole drilling assembly, including the closest three pieces of drill stem, are constructed of non-magnetic steel to prevent magnetic interferences with the steering tool. 
Summary Report of the Drilling Technologies Tested at the Integrated Demonstration Project for Cleanup of Organic Contaminants in Soil and Groundwater at Non-Arid Sites

\section{Drilling Tool}

CEC proposed to use one of two types of drilling tools depending on the hardness of the materials encountered. A hydraulic spud jet, designed to penetrate soft alluvial formations (sands, clayey sands, etc.) similar to the types of sediments present at the M-Area Settling Basin, was planned as the primary drilling tool. An in-hole mud drilling motor was planned to be used if drilling conditions became too difficult for the hydraulic spud jet drilling tool.

The hydraulic spud jet drilling tool (Fig. 4.5.3) was equipped with a $2^{\circ}$ bend in the housing to provide directional drilling capabilities. When the drilling tool is pushed forward without rotation, the tool deviates in the direction of the angle of the tool. To drill without deviation the drilling tool is rotated as it is pushed forward; in this way the tool face does not have a preferred orientation, and the drilling tool advances along a straight path, as in the slant or horizontal sections of the borehole. The tool face orientation is monitored by the steering system. The down-hole drilling assembly produces a hole approximately $31 / 2$ " in diameter.

\section{Steering System}

The orientation and location of the pilot bit was constantly monitored with a "real time" magnetic guidance system (MGS) (Fig. 4.5.4). This MGS enabled the driller to steer the pilot bit into place, and ensure proper borehole alignment and elevation. The MGS was supplied by Sharewell, Inc., a subcontractor to CEC. The MGS enabled the driller to guide the pilot bit by providing immediate gravitational and magnetic information on tool face orientation, azimuth (horizontal location), and inclination (vertical location). The raw data were transmitted to an interface unit at the surface from a down-hole senscr located immediately above the drilling tool or drill motor with a single conductor wire. The surface interface unit displayed tool face orientation, azimuth, and inclination readings. Knowledge of the length of the drill string, azimuth, and inclination allowed the driller to calculate the location of the down-hole sensor and thus the borehole path. Tool face orientation provides information used to determine the steering direction of the drilling tool. The MGS is a proven, accurate system and is hindered only by local magnetic interferences. If magnetic interferences are observed, then a secondary survey system is used. The secondary survey system was not required for this drilling project. 


\subsubsection{Drill Rods}

The drilling method utilizes two drill strings. A small diameter drill string (pilot drill string) is used with the down-hole drilling assembly to drill the pilot hole, and a larger diameter drill string (washover drill string) is drilled over the pilot drill string (Fig. 4.5.5).

The pilot drill string was used to accurately place the pilot hole in the correct location. The pilot drill string is made up of $23 / 16^{\prime \prime}$ outside diameter (OD), 4130 heat-treated steel BCQ drill rods adapted from the mining industry. The length of the pilot drill string rods was limited to 10 feet by the size of the drilling rig.

The washover drill string was used to maintain borehole stability during installation of the horizontal well materials. The $41 / 2 "$ OD, 2160 heat-treated steel washover pipe was drilled circumferentially over the $23 / 16$ " pilot string which served as a guide for the washover pipe until the total drilling distance was achieved. CEC utilized a nine-inch bit for drilling in the washover pipe (Fig. 4.5.6). The length of the washover drill string rods was limited to 10 feet by the size of the drilling rig. During the installation of AMH-6, the 2160 heat-treated steel washover pipe broke downhole. This resulted in $\mathbf{4 8 0}$ feet of washover pipe being left in the borehole, limiting the effective length of the well screen from 400 feet to 225 feet.

\subsubsection{Drilling Fluid System}

The drilling fluid system was typical of a recirculating mud rotary drilling operation. The system included: a mixing tank where the drilling fluid was mixed, a mud pumping system to pump the mud through the hydraulic spud jet, a mud pit to mechanically settle the coarser fraction of suspended drilling solids as it exits from the borehole, and a mud settling tank and desander to remove the finer sand remaining in suspension (Fig. 4.5.7).

The drilling fluid consisted of processed guar gum beans, ground into colloidal particles and mixed with water through a standard mixing jet hopper. Guar gum is a natural polymer that acts to increase the viscosity of the drilling fluid. With bentonite-based drilling fluids, the gel 
Summary Report of the Drilling Technologies Tested at the Integrated Demonstration Project for Cleanup of Organic Contaminants in Soil and Groundwater at Non-Arid Sites

strength or carrying capacity (the size of particles remaining in suspension) is directly related to the viscosity of the drilling fluid. However, with a guar gum-based drilling fluid the gel strength is not directly related to viscosity. Therefore, the carrying capacity of a guar gumbased drilling fluid cannot be predicted by its viscosity. To increase the gel strength of the guar gum-based drilling fluid, the natural polymers must be linked together by an additive. The additive most commonly used is Borax. During this drilling project the guar gum carrying capacity was not enhanced with Borax; therefore drill cuttings were left in the borehole. The drilling fluid needed periodic reconditioning (by simply adding more guar gum) due to the length of the drilling program. Guar gum-based drilling fluids biodegrade naturally within approximately two days.

\subsubsection{Well Materials and Installation}

The well construction materials for AMH-6 consisted of:

- One six-inch long, 3-inch diameter, schedule $\mathbf{4 0}$ polyvinyl chloride (PVC) cap

- Twenty pieces of 20-ft long, flush threaded, 3-inch nominal ID, 0.010-inch slotted schedule 40 PVC screen in the horizontal section below the basin

- Eight pieces of 20-foot long and 16 pieces of 10-foot long, flush threaded, 3-inch nominal ID, schedule 40 PVC riser above the screen.

During the installation of AMH-6, the drillers pushed the end cap off the downhole end of the well screen. A plug, designated as a "one way pig", was installed to within five feet of the end of the screen to reseal the end of the well. The plug consisted of a 6" long, 3.25" diameter polypropylene plug. The total installed depth of well AMH-6 was 720 feet $(710$ feet below ground surface and 10 feet above ground). The total effective screen installed beyond the broken section of washover pipe in AMH-6 is 225 feet ( 710 feet MD minus 480 feet for the broken washover pipe and 5 feet for the plug). 
Summary Report of the Drilling Technologies Tested at the Integrated Demonstration Project for Cleanup of Organic Contaminants in Soils and Groundwater at Non-Arid Sites

The well materials for AMH-7 consisted of:

- One six-inch long, 3-inch diameter, schedule 40 PVC cap

- 21 pieces of 20-ft long, flush threaded, 3-inch nominal inside diameter (ID), 0.010-inch slotted schedule 40 PVC screen in the horizontal section below the basin

- 16 pieces of 20-foot long and 2 pieces of 10-foot long, flush threaded, 3-inch nominal ID, schedule 40 PVC riser above the screen.

The total installed depth of well AMH-7 was 760.5 feet (750.5 feet below ground surface and 10 feet of casing above the ground surface).

Both AMH-6 and AMH-7 were completed using the following method: installing sand by tremmie pipe in the annulus above the well screen; installing a bentonite plug in the annulus above the sand; and filling the annulus with grout from the bentonite plug to the surface (see Figures 4.5.8 and 4.5.9 for AMH-6 and AMH-7 horizontal well construction diagrams). 
Summary Repart of the Drilling Technologies Tested at the Integrated Demonstration Project for Cleanup of Organic Contaminants in Soil and Groundwater at Non-Arid Sites

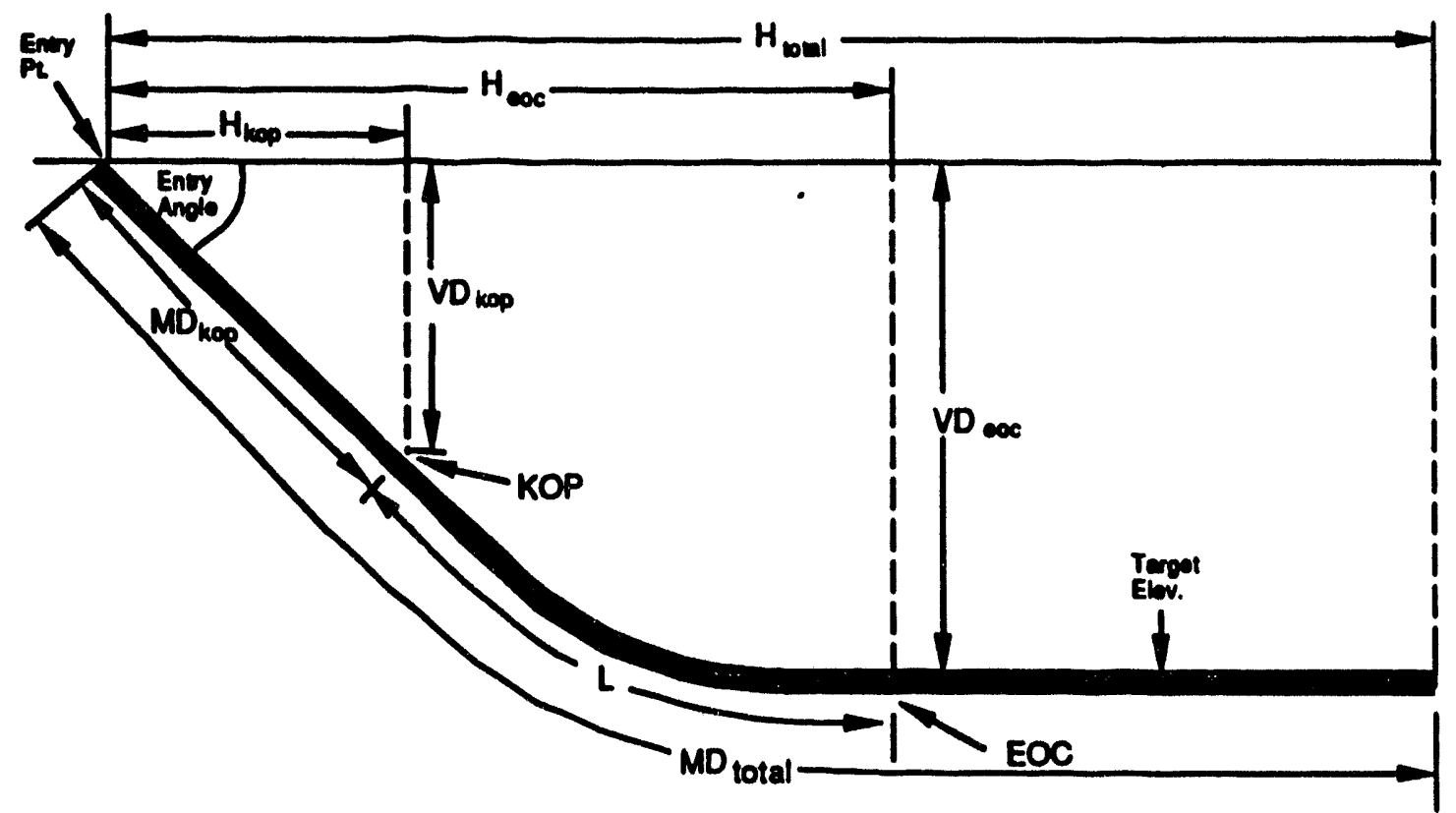

Length of Wel Soreen -

Elavation of Entry .

Elevition of Tamet -

Entry Anolo.

Depen w Tareat -

Radius of Cunature.

Are of 1 degree $($ Redives -1$)=.0174580$

$L$ - Lenoth of Curve a .01745\%s "entry anole" redius of curvature

EOC - End of Curw

$K_{1}$ - Conatent for degreas / $/ \mathrm{t}=(1 / 0.174553) \cdot 100=5730$

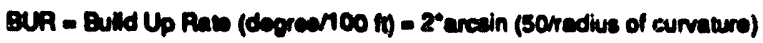

KOP = Mek OF Point

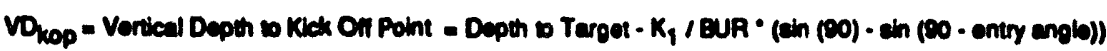

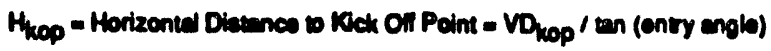

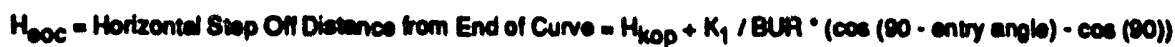

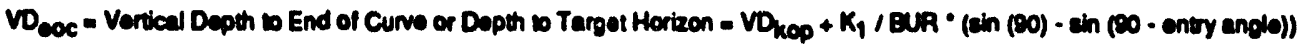

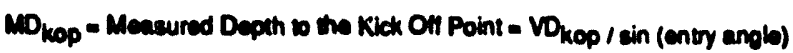

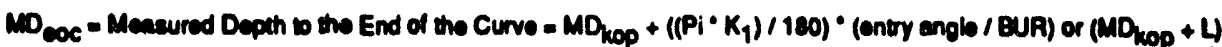

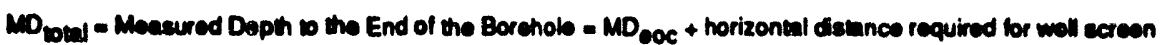

$H_{\text {total }}=H_{\text {coc }}+$ horizontal diances required br woll screen

Fig. 4.1.1 Diagram (in Cross Section) of A Typical Horizontal Well Layout 
Summary Report of the Drilling Technologies Tested at the Integrated Demonstration Project for Cleanup of Organic Contaminants in Soils and Groundwater at Non-Arid Siles

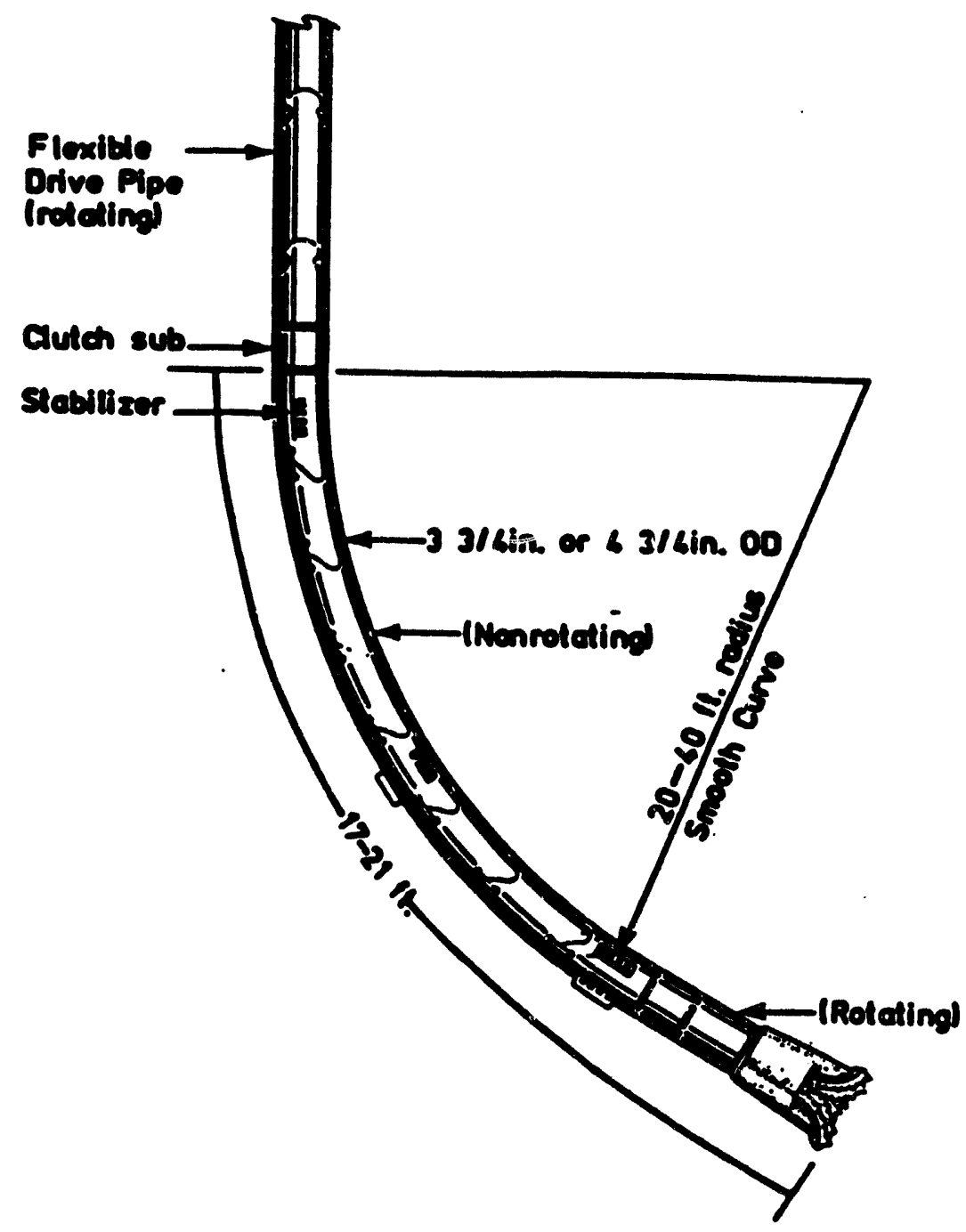

Fig. 4.2.1 Short-Radius Technology Curved Drill Guide 
Summary Report of the Drilling Technologies Tested at the Integrated Demonstration Project for Cleanup of Organic Contaminants in Soil and Groundwater at Non-Arid Sites

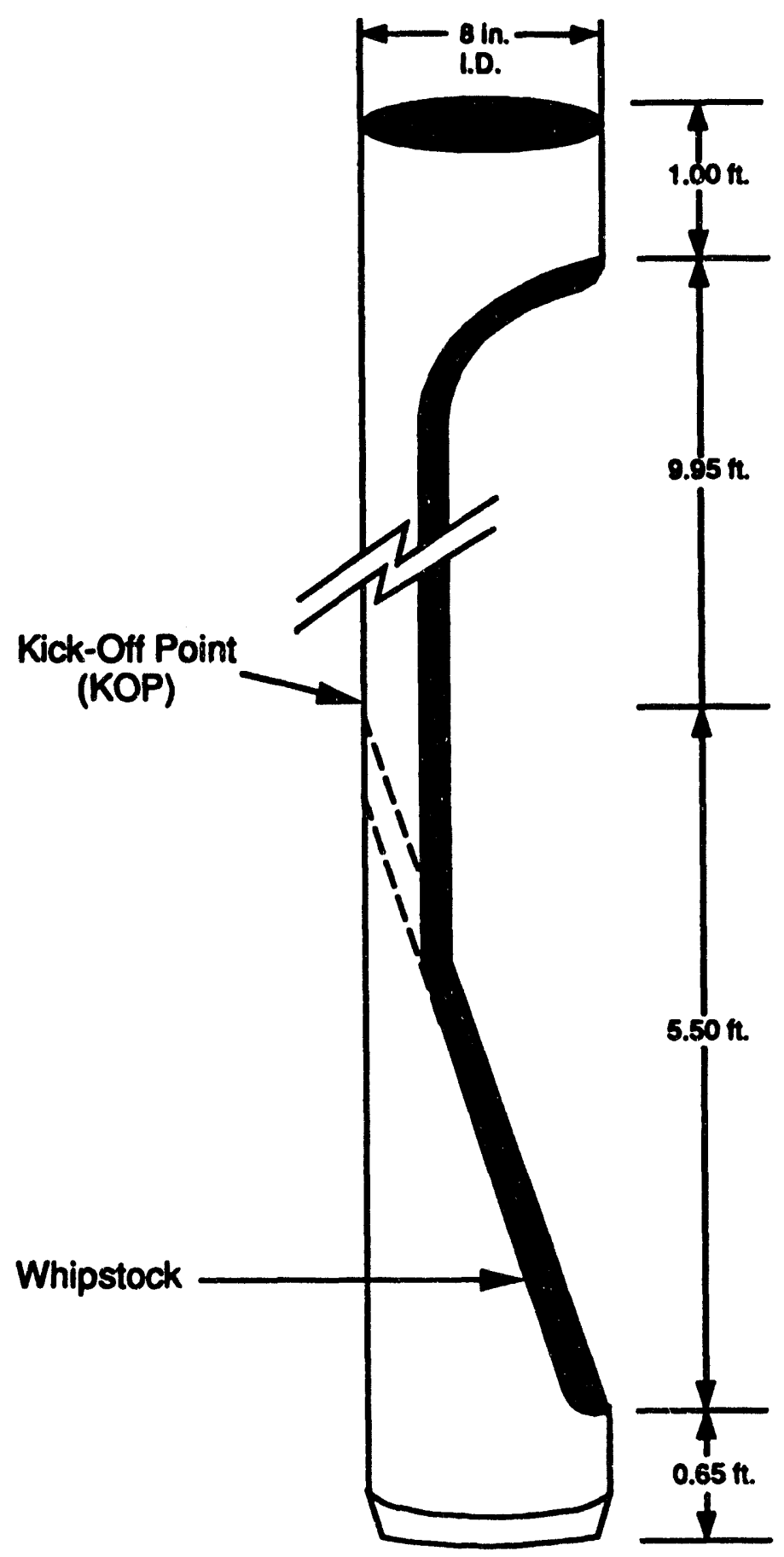

Fig. 4.2.2 Short-Radius Technology -

Schematic Diagram of Whipstock Assembly 
Summary Report of the Drilling Technologies Tested at the Integrated Demonstration Project for Cleanup of Organic Contaminants in Soils and Groundwater at Non-Arid Sites

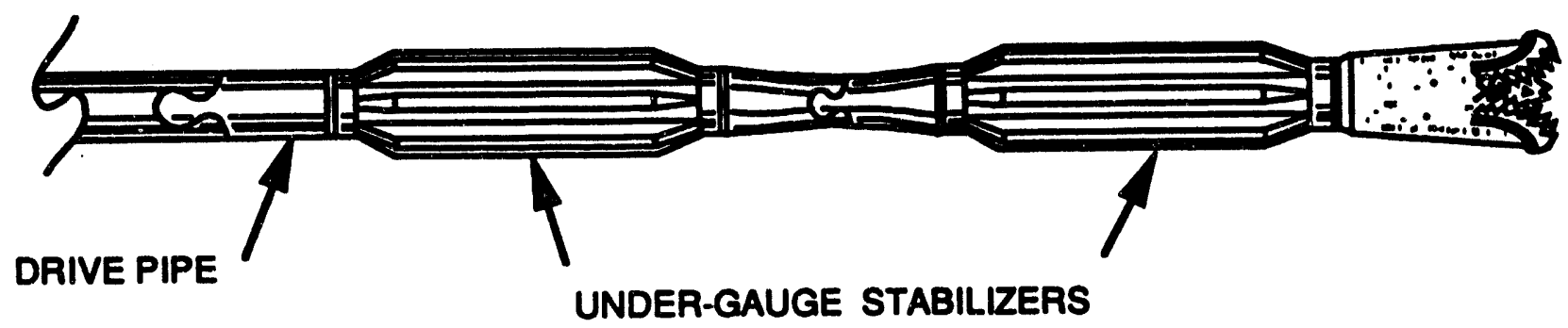

Fig. 4.2.3 Short-Radius Technology -

Rigid Drill Mandrel 
Summary Report of the Drilling Technologies Tested at the Integrated Demonstration Project for Cleanup of Organic Contaminants in Soil and Groundwater at Non-Arid Sites

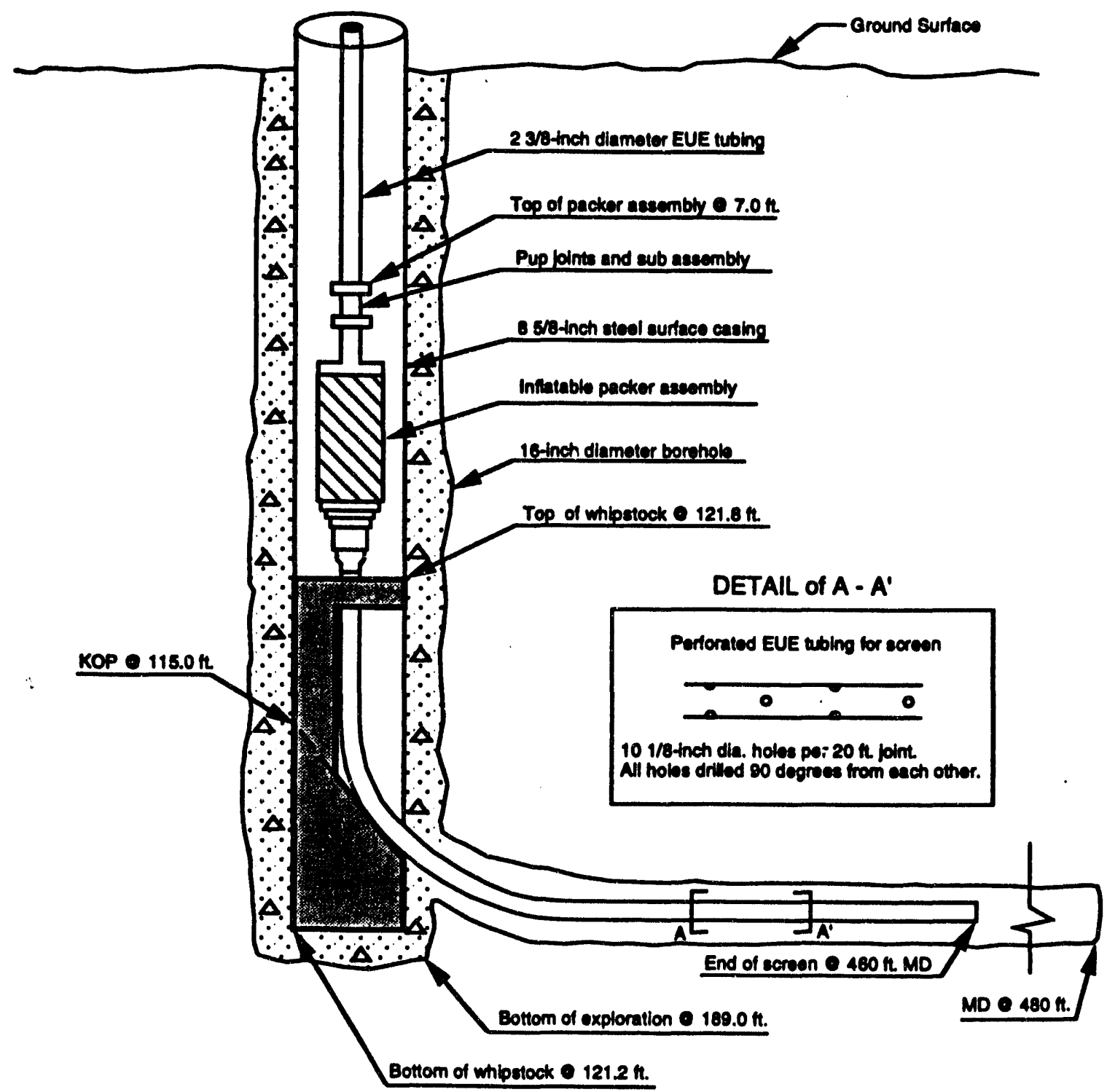

Fig. 4.2.4 Short-Radius Technology -

AMH-1 Horizontal Well Construction Diagram (Water Table Well) 
Summary Report of the Drilling Technologies Tested at the Integrated Demonstration Project for Cleanup of Organic Contaminants in Soils and Groundwater at Non-Arid Sites

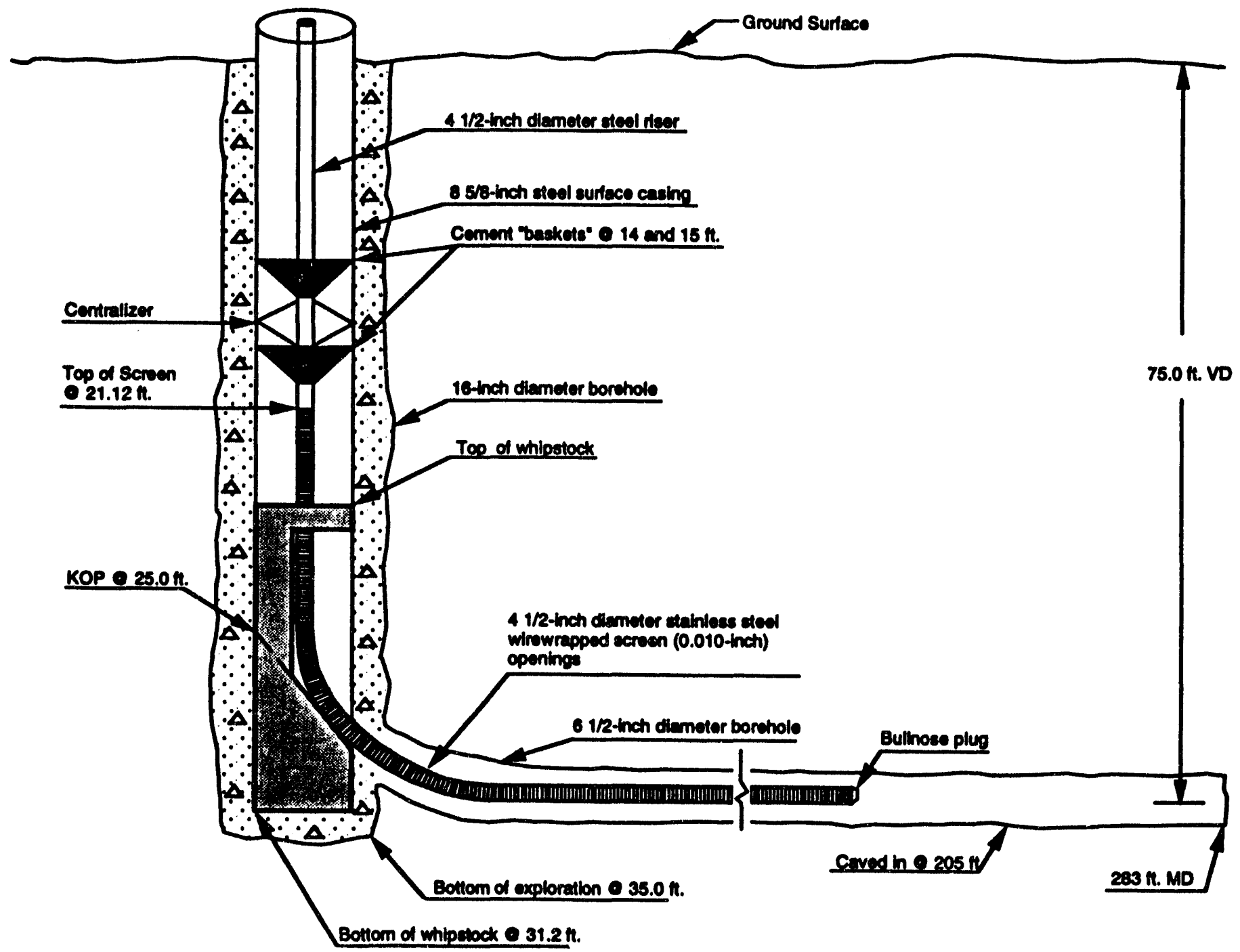

NOT TO SCALE

Fig. 4.2.5 Short-Radius Technology -

AMH-2 Horizontal Well Construction Diagram (Vadose Zone Well) 
Summary Report of the Drilling Technologies Tested at the Integrated Demonstration Project for Cleanup of Organic Contaminants in Soil and Groundwater at Non-Arid Sites

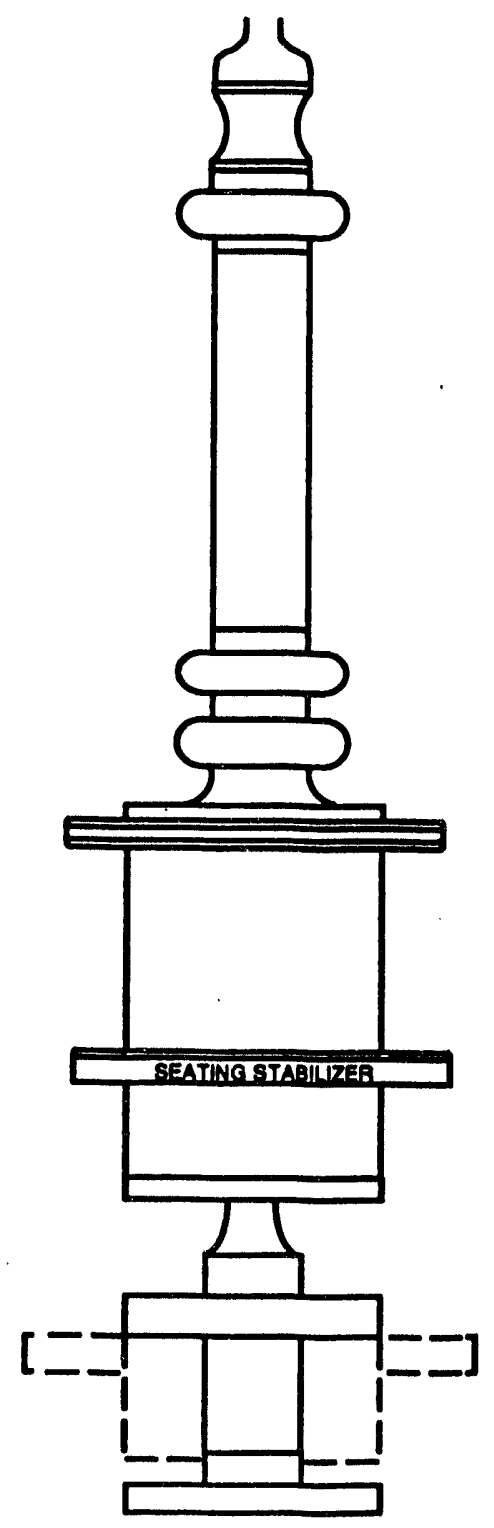

CIRCULATING SUB

TFI SURVEY PACKAGE WITH KNUCKLE JOINT

MOTOR INCLUDING

KNUCKLE JOINTS

BIT WITH

EXPANDING

WINGS

Fig. 4.3.1 Modified Petroleum Industry Technology Non-Magnetic Bottom Hole Assembly (BHA) 
Summary Report of the Drilling Technologies Tested at the Integrated Demonstration Project for Cleanup of Organic Contaminants in Soils and Groundwater at Non-Arid Sites

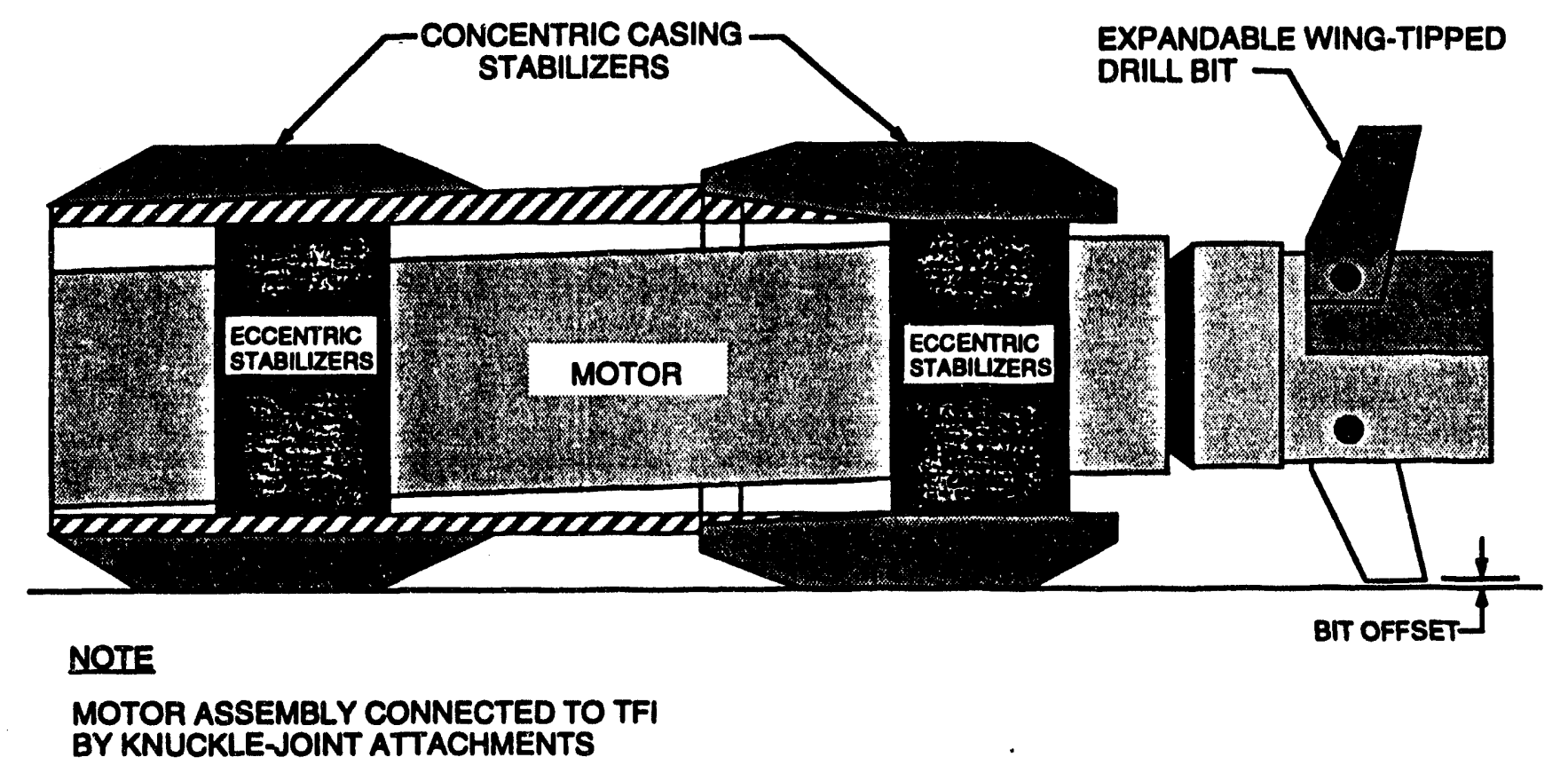

NOT TOSCALE

Fig. 4.3.2 Modified Petroleum Industry Technology - Schematic of DownHole Motor with Stabilizers 
Summary Report of the Drilling Technologies Tested at the Integrated Demonstration Project for Cleanup of Organic Contaminants in Soil and Groundwater at Non-Arid Sites

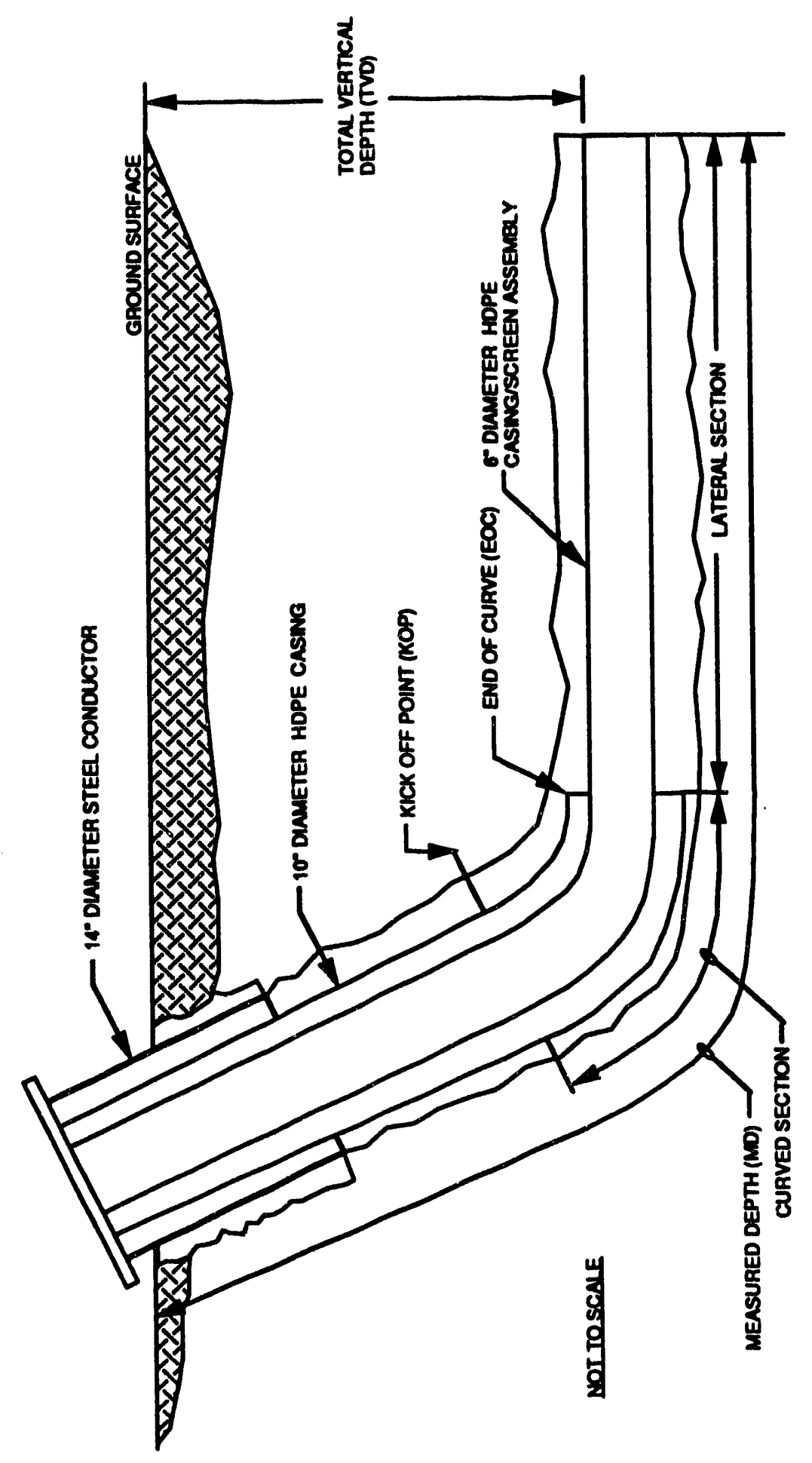

Fig. 4.3.3 Modified Petroleum Industry Technology •

Well Section Orientation and Associated Technology 
Summary Report of the Drilling Technologies Tested at the Integrated Demonstration Project for Cleanup of Organic Contaminants in Soils and Groundwater at Non-Arid Sites

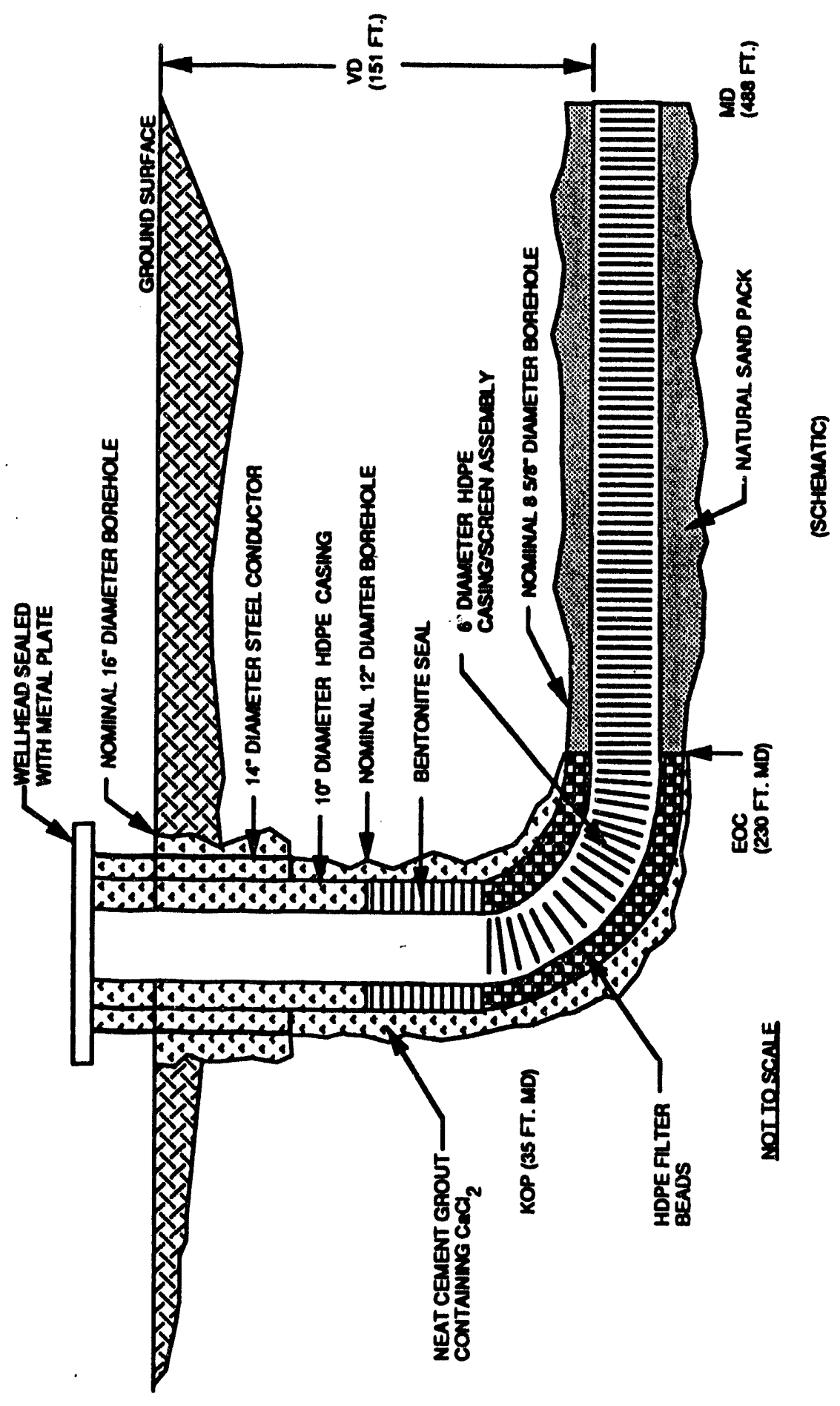

Fig. 4.3.4 Modified Petroleum Industry Technology AMH-3 Horizontal Well Construction Diagram (Water Table Well) 
Summary Report of the Drilling Technologies Tested at the Integrated Demonstration Project for Cleanup of Organic Contaminants in Soil and Groundwater at Non-Arid Sites

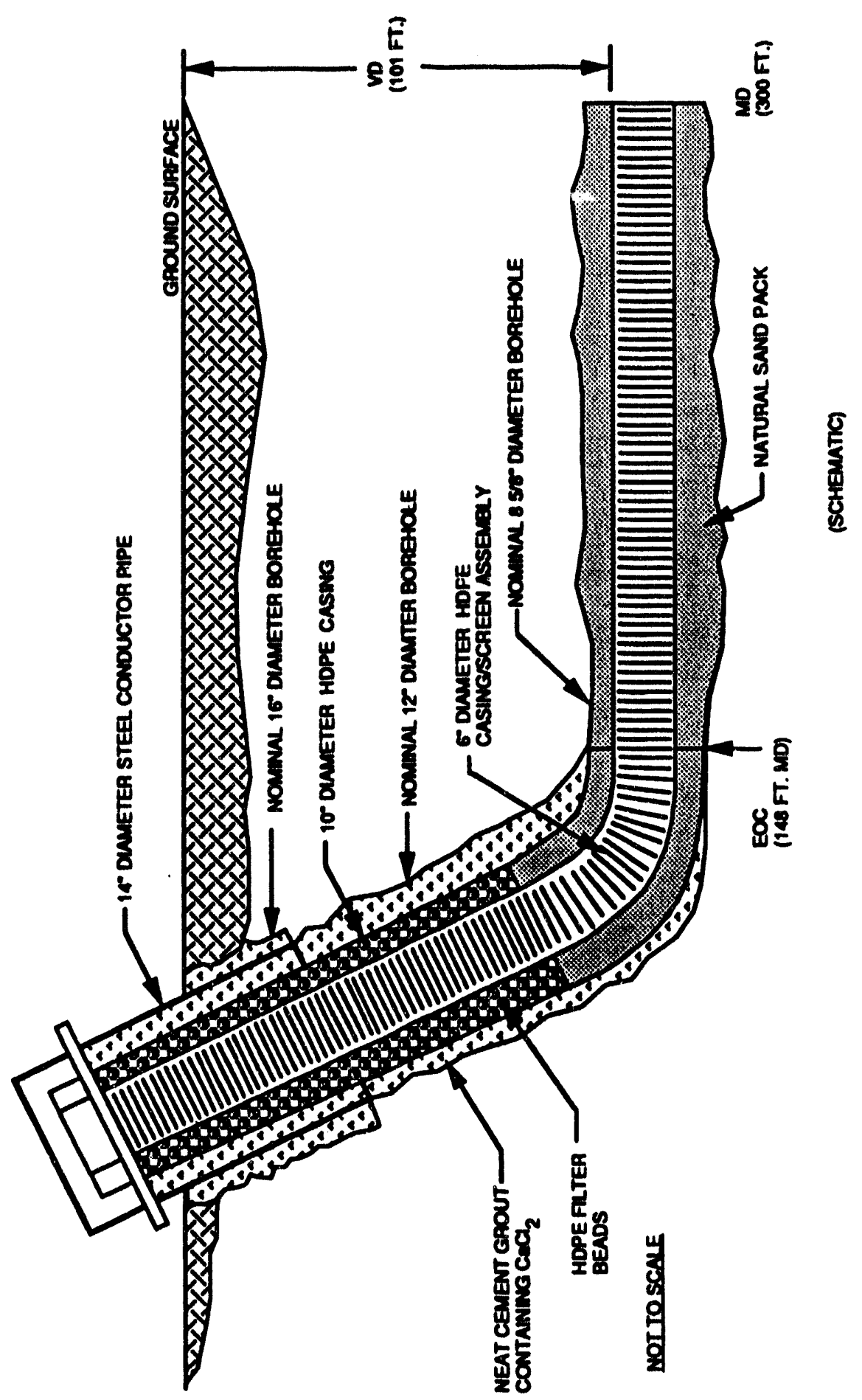

Fig. 4.3.5 Modified Petroleum Industry Technology AMH-4 Horizontal Well Construction Diagram (Vadose Zone Well) 
Summary Report of the Drilling Technologics Tested at the Integrated Demonstration Project for Cleanup of Organic Contaminants in Soils and Groundwater at Non-Arid Sitcs

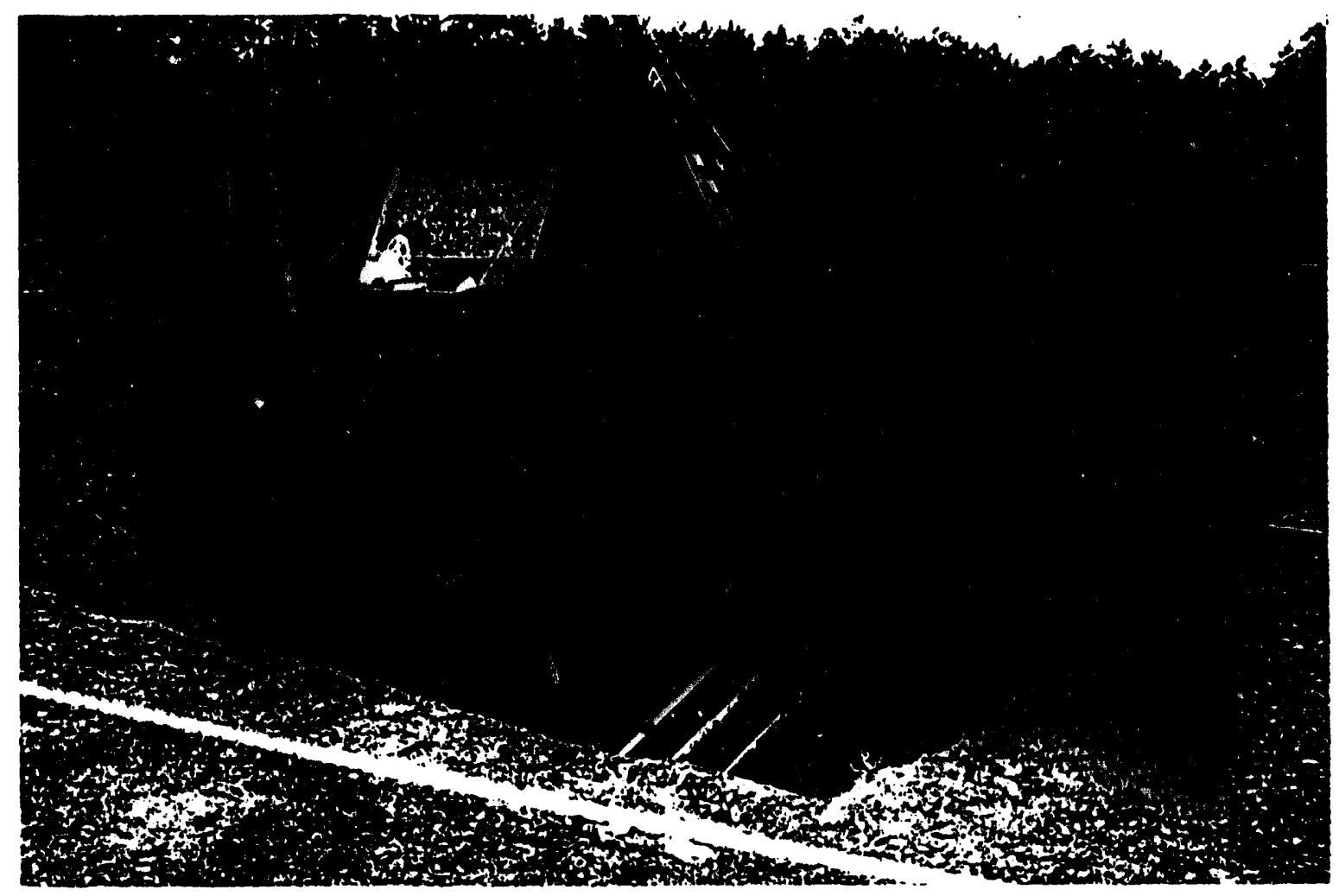

Fig. 4.4.1 Utility Industry Compactional Drilling Technology Oblique View of X-810 Experimental Drilling Rig 
Summary Report of the Drilling Technologies Tested at the Integrated Demonstration Project for Cleanup of Organic Contaminants in Soil and Groundwater at Non-Arid Sites

THIS PAGE LEFT INTENTIONALLY LEFT BLANK 
Summary Report of the Drilling Technologies Tested at the Integrated Demonstration Project for Cleanup of Organic Contaminants in Soils and Groundwater at Non-Arid Sites

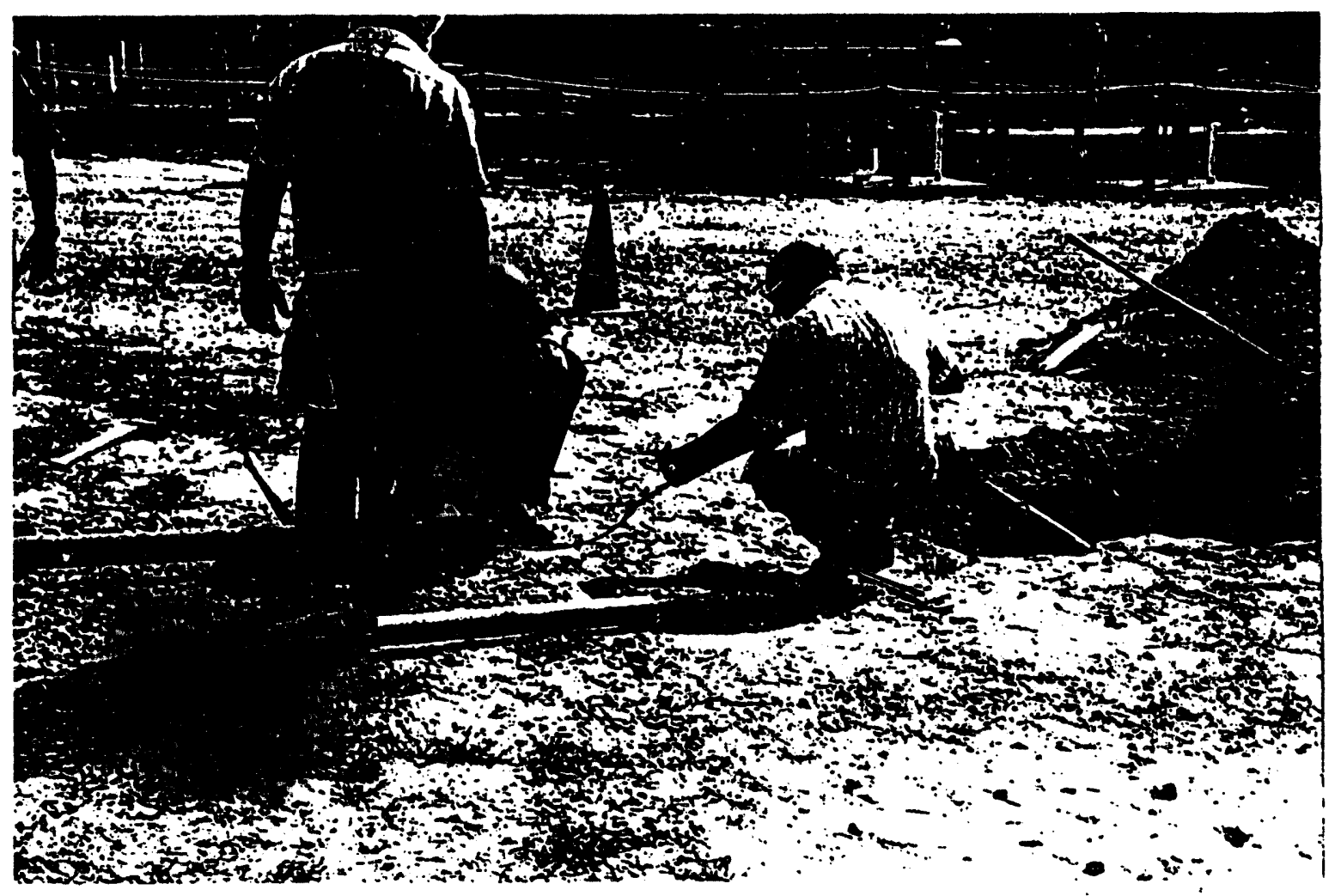

Fig. 4.4.2 Utility Industry Compactional Drilling Technology Down-Hole Assembly 
Summary Report of the Drilling Technologies Tested at the Integrated Demonstration Project for Cleanup of Organic Contaminants in Soil and Groundwater at Non-Arid Sites

THIS PAGE LEFT INTENTIONALLY LEFT BLANK 
Summary Report of the Drilling Technologies Tested at the Integrated Demonstration Project for Cleanup of Organic Contaminants in Soils and Groundwater at Non-Arid Sites

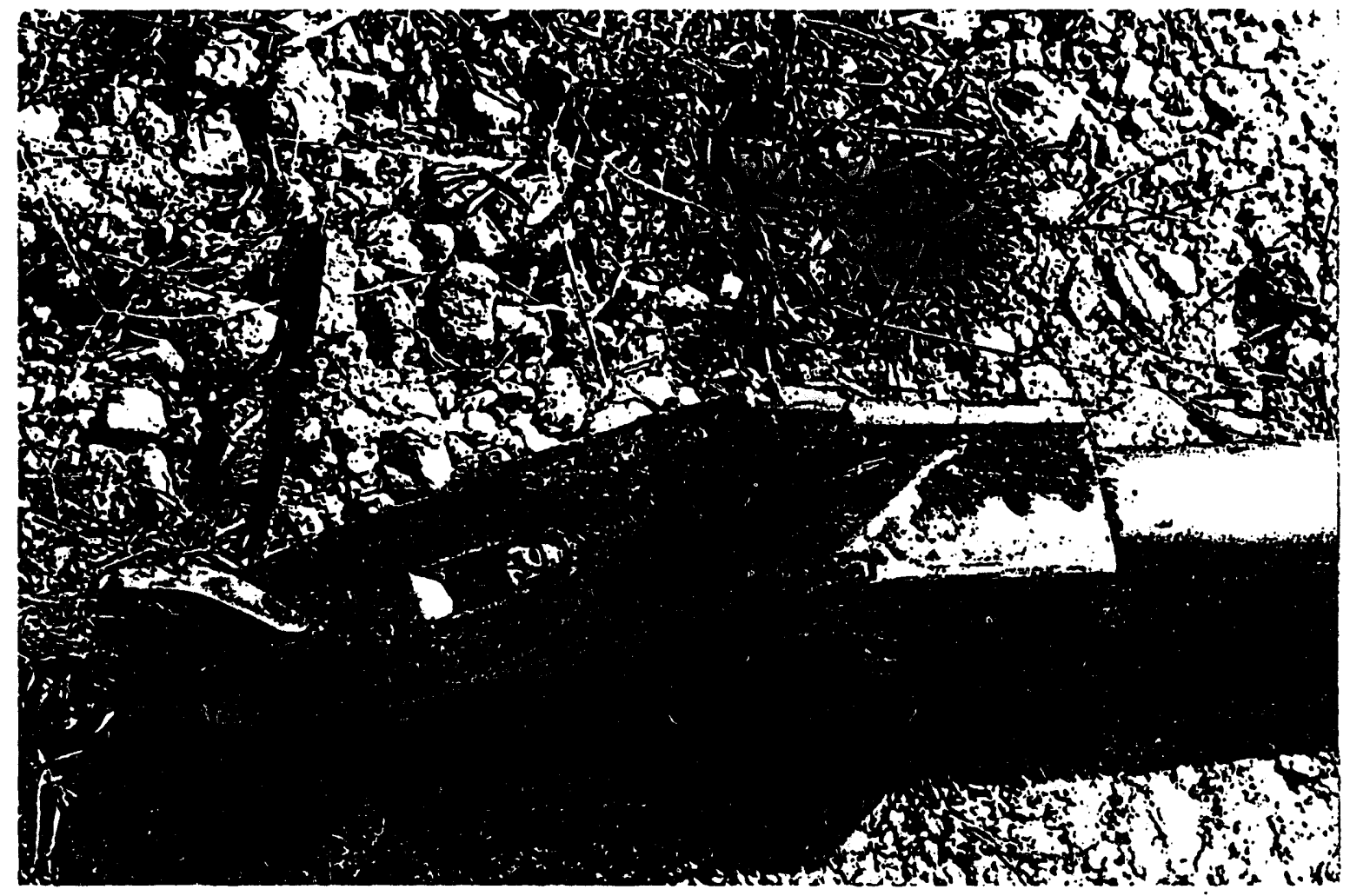

Fig. 4.4.3 Utility Industry Compactional Drilling Technology Patented Directional Drilling Tool 
Summary Report of the Drilling Technologies Tested at the Integrated Demonstration Project for Cleanup of Organic Contaminants in Soil and Groundwater at Non-Arid Sites

THIS PAGE LEFT INTENTIONALLY LEFT BLANK 


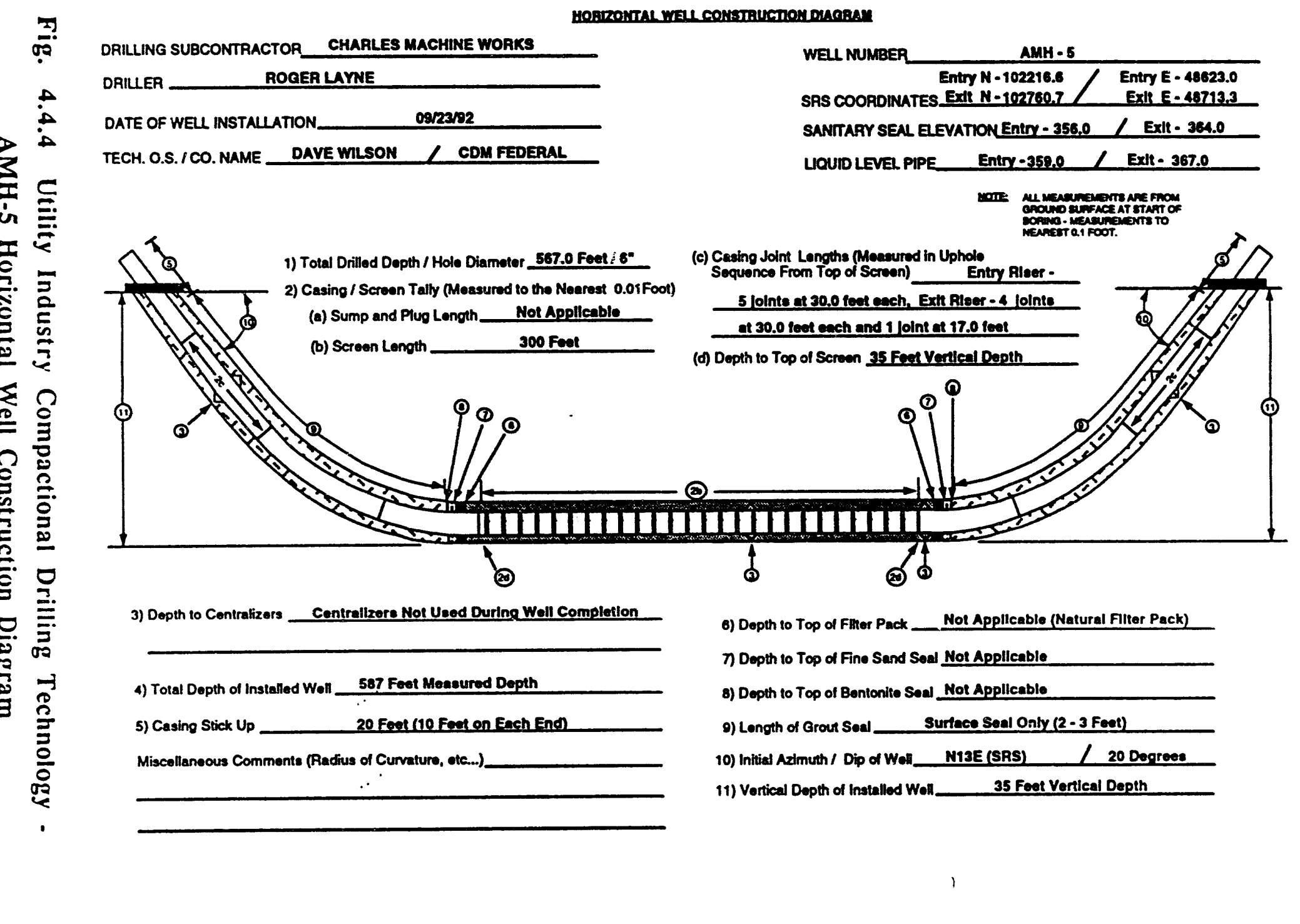


Summary Report of the Drilling Technologies Tested at the Integrated Demonstration Project for Cleanup of Organic Contaminants in Soil and Groundwater at Non-Asid Sites

THIS PAGE LEFT INTENTIONALLY LEFT BLANK 
Summary Report of the Drilling Technologies Tested at the Integrated Demonstration Project for Cleanup of Organic Contaminants in Soils and Groundwater at Non-Arid Sitcs

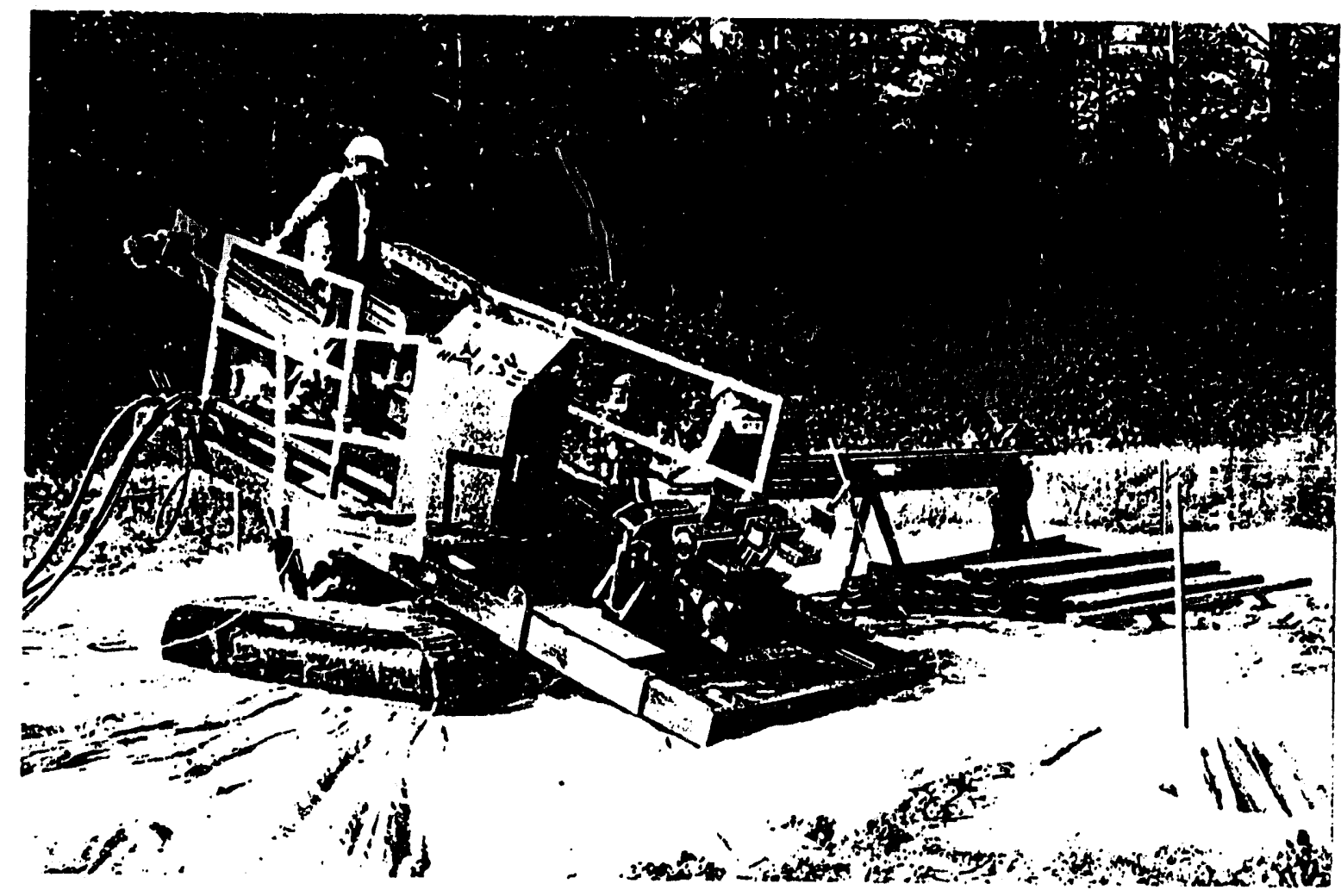

Fig. 4.5.1 River Crossing Industry Drilling Technology Oblique View of MC-90 Drilling Rig 
Summary Report of the Drilling Technologies Tested at the Integrated Demonstration Project for Cleanup of Organic Contaminants in Soil and Groundwater at Non-Arid Sites

THIS PAGE LEFT INTENTIONALLY LEFT BLANK 
Summary Report of the Drilling Technologies Tested at the Integrated Demonstration Project for Cleanup of Organic Contaminants in Soils and Groundwater at Non-Arid Sites

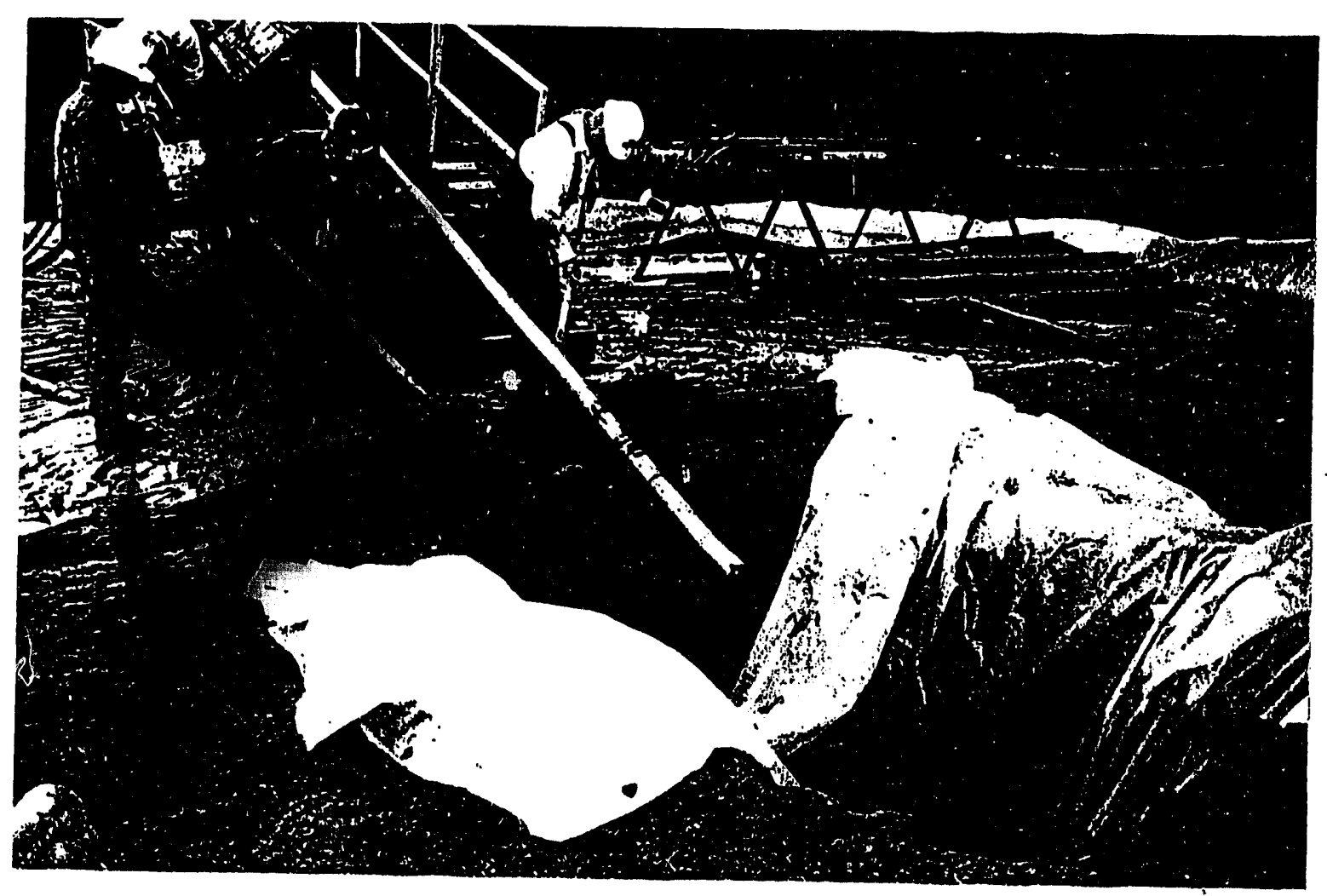

Fig. 4.5.2 River Crossing Industry Drilling Technology Down-Hole Drilling Assembly 
Summary Report of the Drilling Technologies Tested at the Integrated Demonstration Project for Cleanup of Organic Contaminants in Soil and Groundwater at Non-Arid Sites

THIS PAGE LEFT INTENTIONALLY LEFT BLANK 
Summary Report of the Drilling Technologies Tested at the Integrated Demonstration Project for Cleanup of Organic Contaminants in Soils and Groundwater at Non-Arid Sites

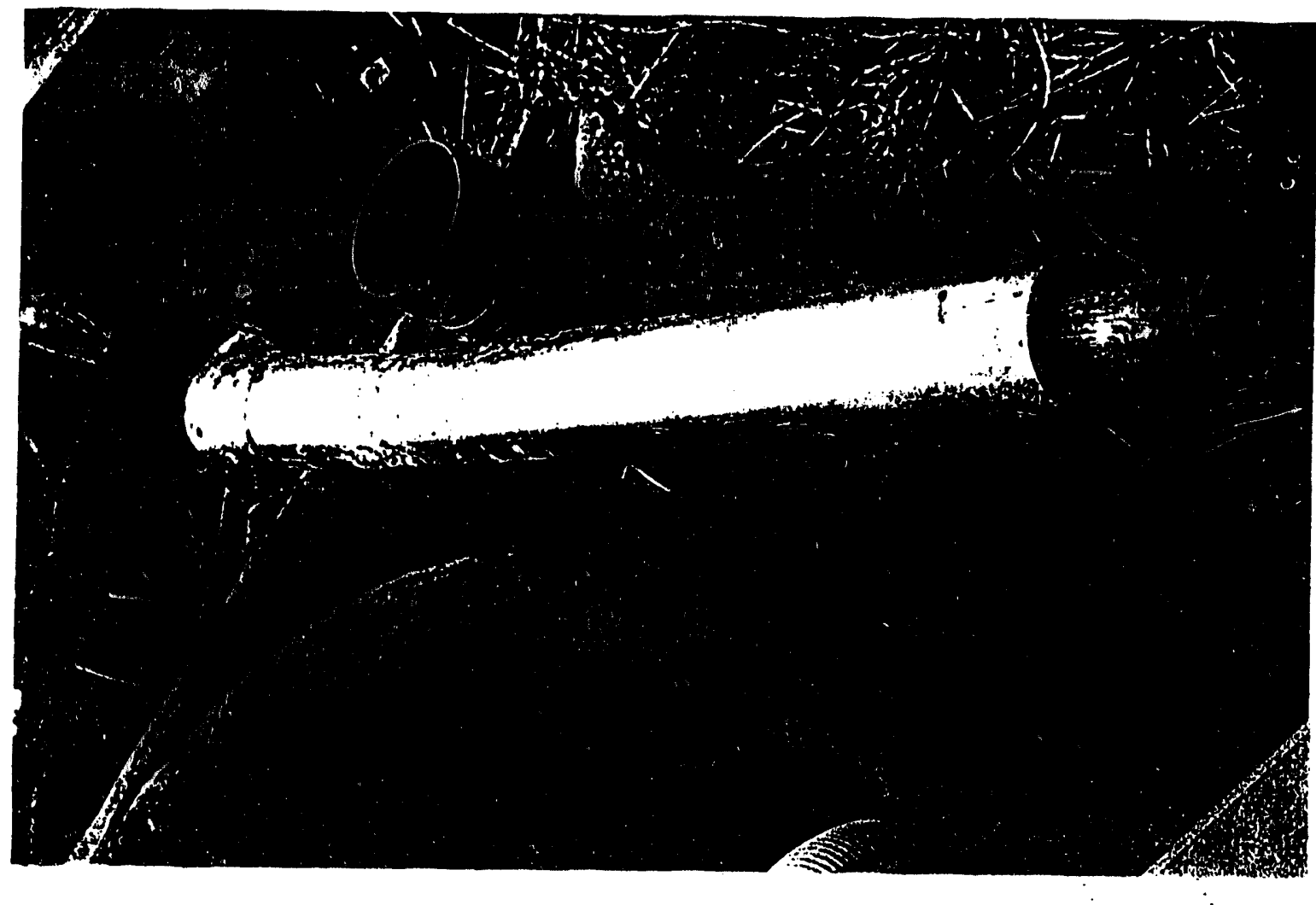

Fig. 4.5.3 River Crossing Industry Drilling Technology Directional Drilling Tool 
Summary Report of the Drilling Technologies Tested at the Integrated Demonstration Project for Cleanup of Organic Contaminants in Soil and Groundwater at Non-Arid Sites

THIS PAGE LEFT INTENTIONALLY LEFT BLANK 
Summary Report of the Drilling Technologies Tested at the Integrated Demonstration Project for Cleanup of Organic Contaminants in Soils and Groundwater at Non-Arid Sites

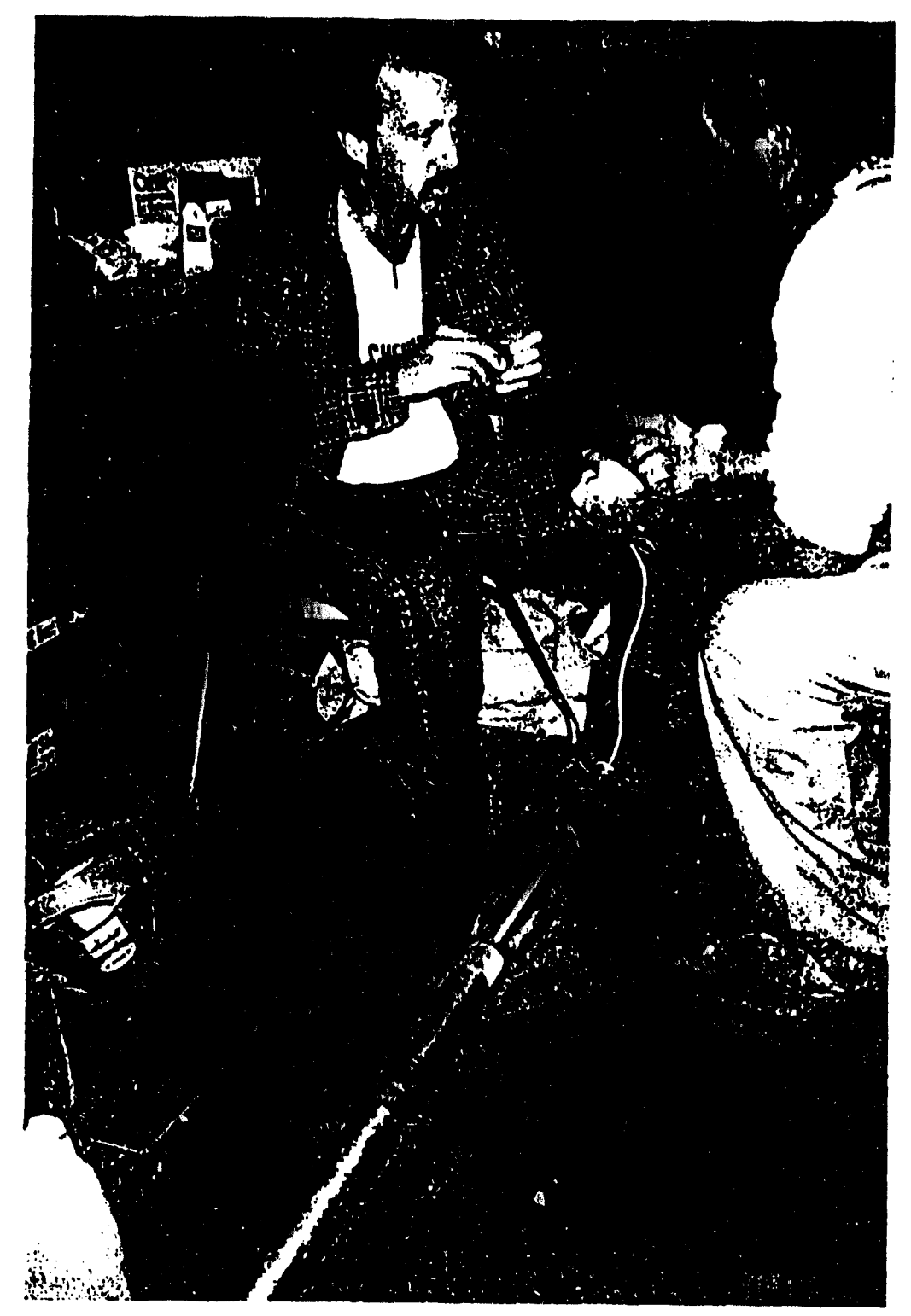

Fig. 4.5.4 River Crossing Industry Drilling Technology Magnetic Guidance System (M(;S) 
Summary Report of the Drilling Technologies Tested at the Integrated Demonstration Project for Cleanup of Organic Contaminants in Soil and Groundwater at Non-Arid Sites

THIS PAGE LEFT INTENTIONALLY LEFT BLANK 
Summary Report of the Drilling Technologics Tested at the Integrated Demonstration Project for Cleanup of Organic Contaminants in Soils and Groundivater at Non-Arid Sitcs

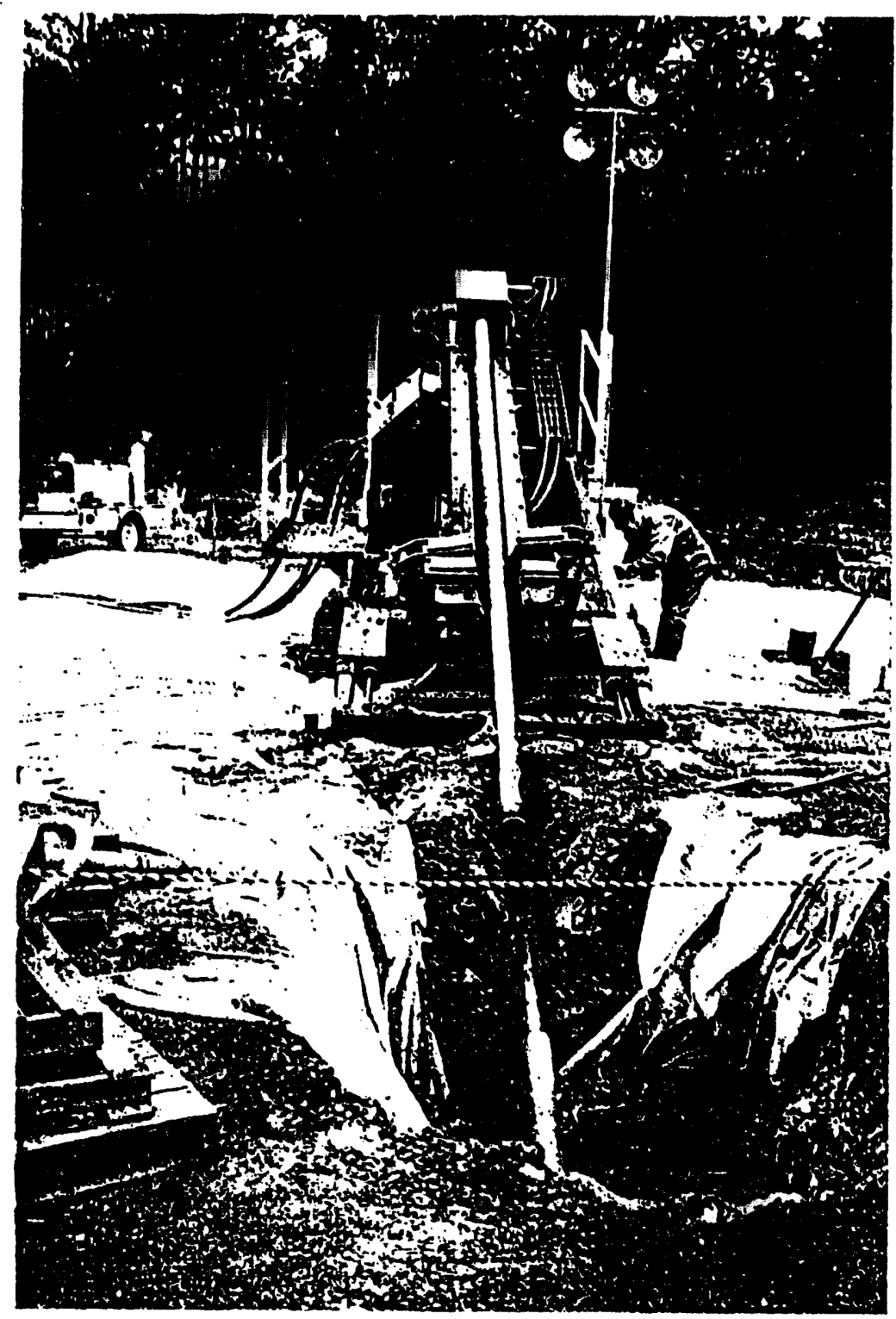

Fig. 4.5.5 River C'rossing Industry Drilling Technology Drill String Assembly 
Summary Report of the Drilling Technologies Tested at the Integrated Demonstration Project for Cleanup of Organic Contaminants in Soil and Groundwater at Non-Arid Sites

THIS PAGE LEFT INTENTIONALLY LEFT BLANK 
Summary R.cport of the Drilling Technologies Tested at the Integrated Demonstration Project for Cleanup of Organic Contamninants in Soils and Groundwater at Non-Arid Sites

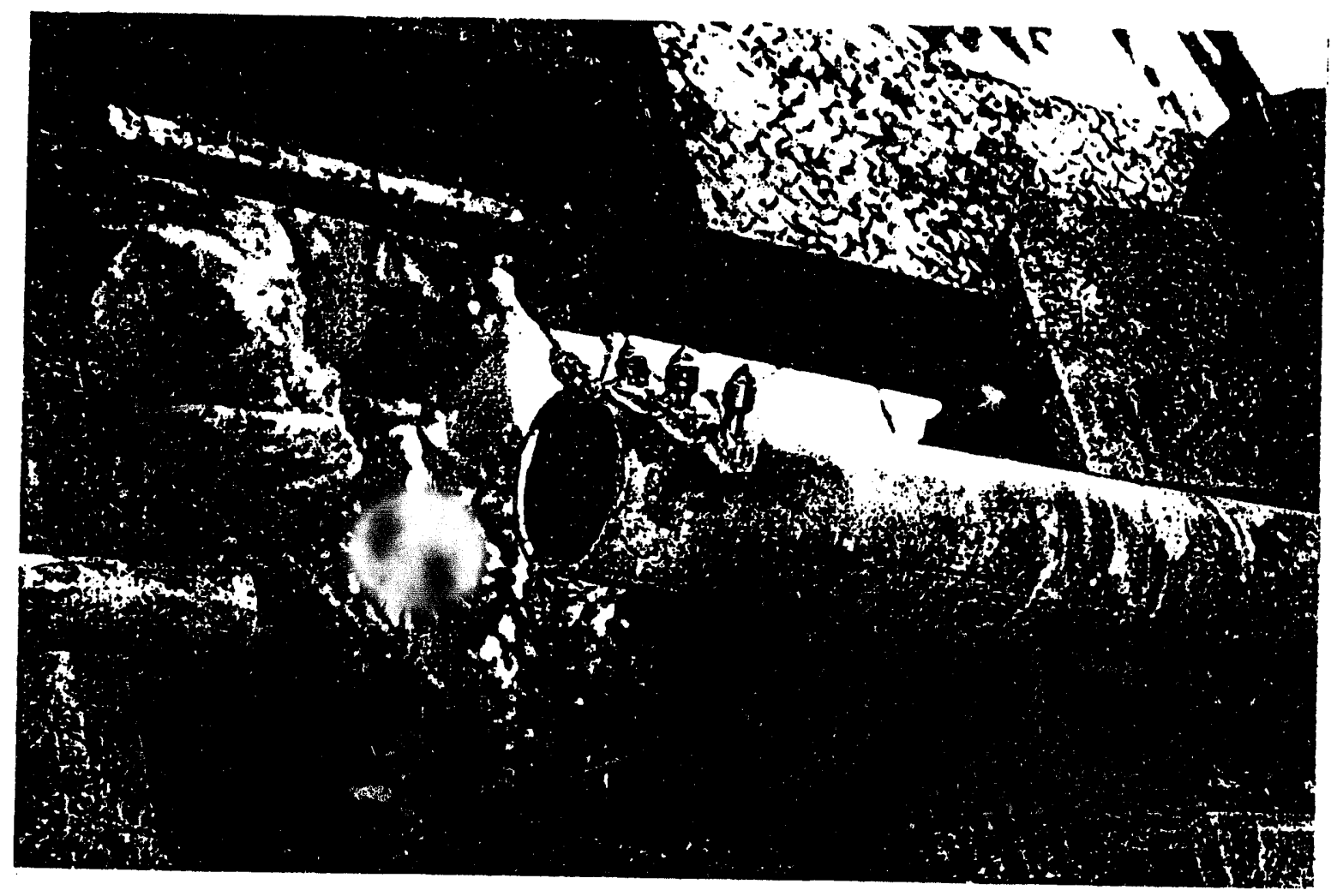

Figg. 4.5.6 River Crossing Industry Drilling Technology Nine-Inch Drill Bit Attached to Washover Pipe 
Summary Report of the Drilling Technologies Tested at the Integrated Demonstration Project for Cleanup of Organic Contaminants in Soil and Groundwater at Non-Arid Sites

THIS PAGE LEFT INTENTIONALLY LEFT BLANK 
Summary Report of the Drilling Technologics Tested at the Integrated Demonstration Project for Cleanup of Organic Contaminants in Soits and Groundivater at Non-Arid Sitcs

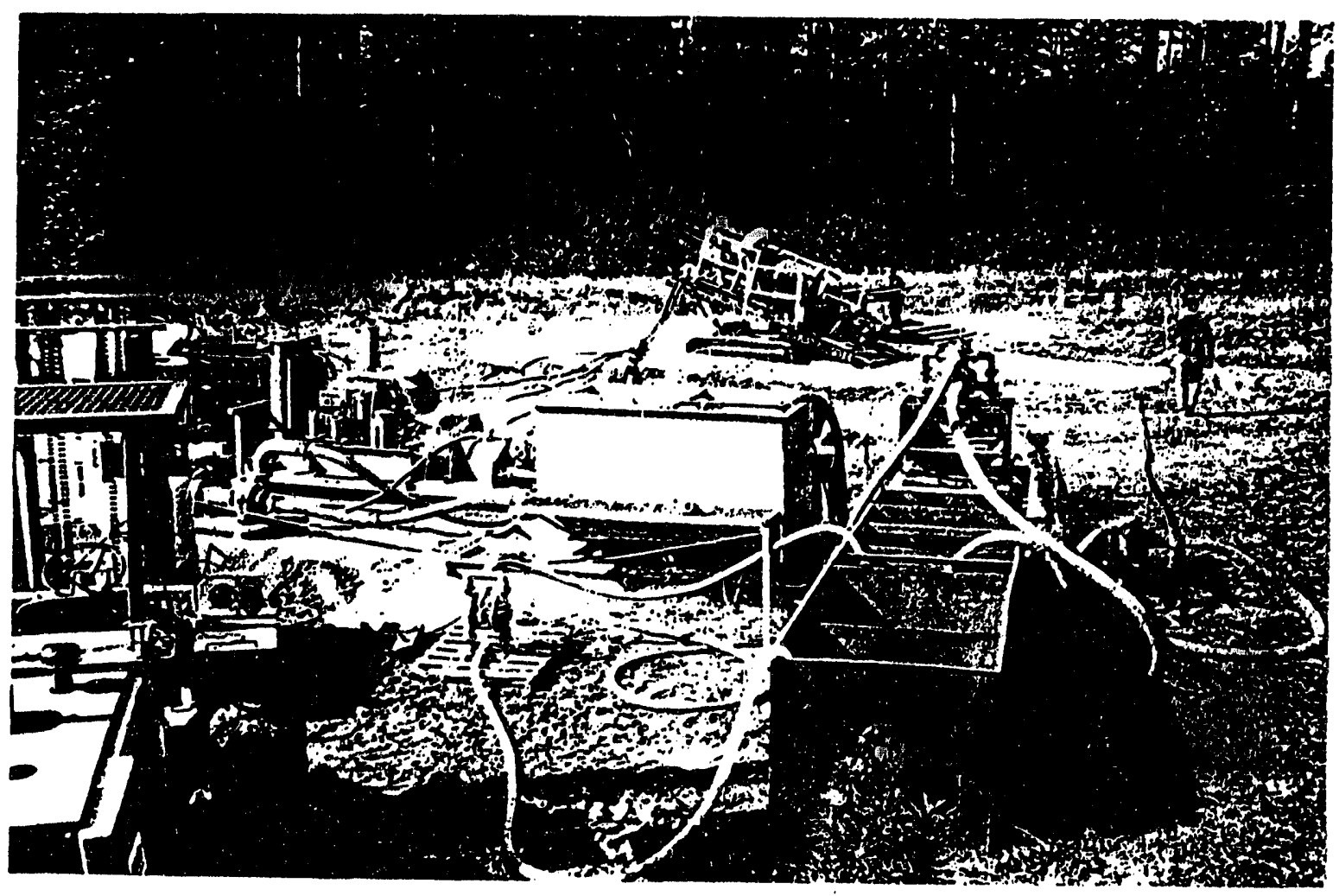

Fig. 4.5.7 River Crossing Industry Drilling Technology Mud System Set-up 
Summary Report of the Drilling Technologies Tested at the Integrated Demonstration Project for Cleanup of Organic Contaminants in Soil and Groundwater at Non-Arid Sites

THIS PAGE LEFT INTENTIONALLY LEFT BLANK 


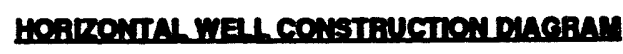

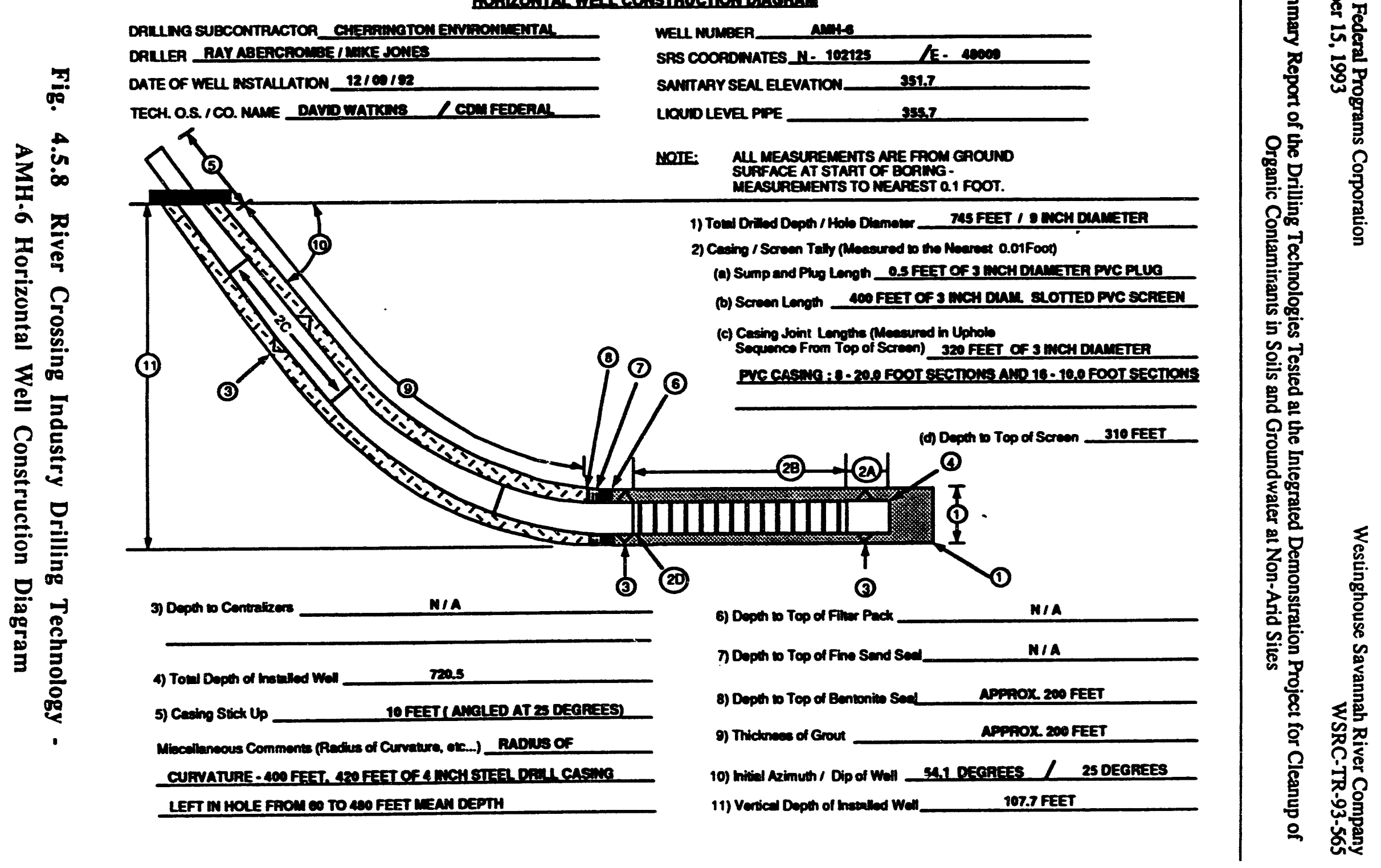


Summary Report of the Drilling Technologies Tested at the Integrated Demonstration Project for Cleanup of Organic Contaminants in Soil and Groundwater at Non-Arid Sites

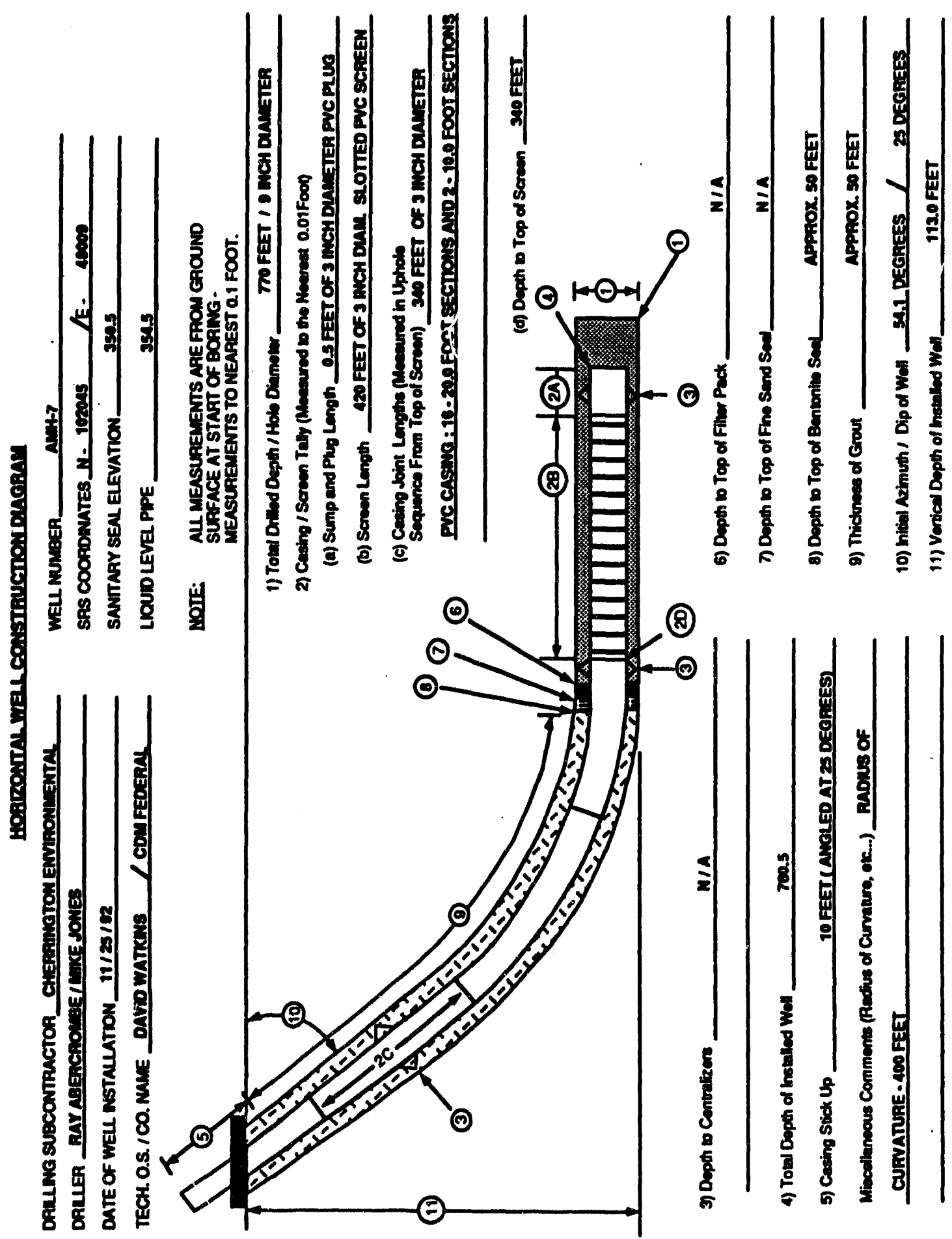

Fig. 4.5.9 River Crossing Industry Drilling Technology • AMH-7 Horizontal Well Construction Diagram 
Summary Report of the Drilling Technologies Tested at the Integrated Demonstration Project for Cleanup of Organic Contaminants in Soils and Groundwater at Non-Arid Sites

\subsection{PERFORMANCE OF BOREHOLE DRILLING AND WELL INSTALLATION TECHNOLOGIES}

The ultimate success of a horizontal environmental well depends on whether the borehole is drilled in the proper location with minimum damage to the host formation, the well materials are installed in the borehole, and the well meets the designated remediation objectives. The latter criteria will not be discussed in this report because evaluations have not been performed on all the wells to this date. This section contains a summary of the performance of each drilling and well installation technology and the geological and logistical compatability of each technology.

\subsection{Borehole Drilling Performance}

The borehole drilling performance may be evaluated by comparing the final location of the borehole with the design specifications, the efficacy of the drilling method in the site geology, and the technical efficiency of the drilling method. This section contains a summary of the success each drilling technology had meeting well design criteria, discussions of the drilling technologies' ability to adapt to the geological conditions at the IDP site, and the technologies' performance unrelated to geology.

\subsubsection{Meeting Well Design Criteria}

The environmental problem holder will design the horizontal well so that the position of the well screen maximizes the remediation effort. The position of the well screen depends on the position and condition of the borehole. A horizontal drilling program is successful if the borehole meets the following criteria.

- The borehole curve must end at the proper elevation and azimuth. The drilling technology must have the ability to drill the curved section(s) of borehole and maintain the proper azimuth and elevation. The elevation and the azimuth of the borehole at the end of the curve will determine the orientation and placement of the horizontal section of the borehole. 
Summary Report of the Drilling Technologies Tested at the Integrated Demonstration Project for Cleanup of Organic Contaminants in Soil and Groundwater at Non-Arid Sites

sensitive areas preclude the use of pit-launched drilling programs. The anchor system on the drilling rig should be improved so that a surface-launched borehole can provide maximum pushing and pulling capacity.

The final drilling tool used during the third completion was not tested while rotating because it followed the original borehole. However, this final drilling tool was significantly more aggressive than the previous tools with carbide cutters along both sides of the wedge face as well as larger carbide cutters at the tip and base of the tool (Fig. 4.4.3). The final drilling tool was also fitted with a larger fluid port in order to deliver more drilling fluid for cooling and lubricating the drilling tool and to possibly aid in cutting the formation.

The guidance system proved to be adequate for the requirements of this drilling program, but the system needs to be improved to provide more accurate results. Some suggested improvements are:

- A temperature sensor to prevent overheating of the down-hole tool.

- Improved azimuth resolution, especially when the tool is used along north-south lines.

- A computer link to the drilling console to provide better tracking of the borehole.

- A secondary method (one-shot survey) to confirm the Drill Scout ${ }^{\mathrm{TM}}$ readings. $^{-}$

\subsubsection{River Crossing Industry Drilling Technology}

Technological factors that controlled the drilling performance were the inexperience of the drilling crew, a deficient washover pipe, an ineffective drilling fluid system, and other factors. These factors will be discussed below.

\section{Drilling Crew}

The CEC drilling crew consisted of two crews. The night crew worked from 7:00 pm to 7:00 am. The night crew chief was the Vice President of Operations for CEC. The day crew worked from 7:00 am to 7:00 pm. The day crew chief was operating the drilling rig for the first time. Both crews were relatively inexperienced in deep (greater than 50 feet vertical depth) 
Summary Report of the Drilling Technologies Tested at the Integrated Demonstration Project for Cleanup of Organic Contaminants in Soils and Groundwater at Non-Arid Sites

environmental well installation. The inexperience of the drilling crews was demonstrated in their inability or reluctance to adapt their drilling methods to the site specific drilling conditions. Two aspects of their drilling method which needed to be adapted for this drilling project were washover pipe installation and the drilling fluid system.

The $\mathbf{4 1 3 0}$ heat-treated two-inch steel pilot drill pipe used proved to be adequate for drilling in the coastal plain sands and clays. However, the 2160 four-inch washover pipe (used by mistake instead of 4130 pipe) proved to be inadequate. This type of washover pipe broke on several occasions with the box of the downhole pipe breaking off on the pin of the pipe above it. The joints of the washover pipe were too weak to withstand the oblique stresses experienced while the pipe was rotated and/or pushed through the curved section of the borehole. After the first attempt at constructing the AMH-6 borehole failed, the radii of curvature of the borehole paths were increased from 300 feet to 400 feet. The increased radius of curvature was supposed to decrease the oblique stresses experienced by the joints of the washover pipe. No other changes were made in the drilling operation to prevent the washover pipe joints from breaking until well into the project after the washover pipe had broken numerous times. Changes that were made included rotation of the washover pipe slowed to approximately $30 \mathrm{rpms}$ and the push pressure reduced. By that time, the washover pipe was well worn and more fragile, and thus the changes did not significantly improve the drilling performance. Later in the drilling project 4130 washover pipe was shipped to the drill site and used to extract the broken sections of 2160 pipe. No problems were encountered with any of the new $\mathbf{4 1 3 0}$ washover pipe.

Drilling fluid circulation was often lost during the drilling project. The drilling crew used the following methods to mitigate the fluid loss:

- The drill crew thickened the drilling fluid by quickly mixing the guar gum at a rate that prevents total dissolution of the guar gum in the drilling fluid. The result was clumps of guar gum powder (known as "fish eyes") that float in the drilling fluid. The purpose of the fish eyes was to flnw into and plug any cavities in the area of the borehole that was experiencing the fluid loss. 
Summary Report of the Drilling Technologics. Tested at the Integrated Demonstration Project for Cleanup of Organic Contaminants in Soil and Groundwater at Non-Arid Sites

- The drill crew drilled the washover pipe past the zone where drilling fluid was being lost. This method only regains fluid circulation while drilling the pilot drill stem and is not effective if fluid loss occurs while advancing the washover pipe.

These two methods of drilling fluid loss mitigation may work at some drilling sites; however, they did not work at this site. The crew kept trying the above listed methods regardless of the efficacy of their efforts. The inability of the drilling crews to deal with these two drilling challenges resulted in many additional man hours of drilling, loss of drilling fluids to the formation, and because drilling fluid loss caused the washover pipe to become stuck in the borehole, loss of drilling materials.

\section{Drilling Eluid System}

The drilling fluid system contained one small desander that early in the drilling project proved ineffective in removing fine sediments from the drilling fluid. The purpose of the desander was to remove fine sediments from the drilling fluid as it circulated from the borehole to the mud mixing tank. Drilling activities were stopped numerous times to allow the drilling crew to remove fine sand from the mud mixing tank that should have been removed by the desander. The desander was not replaced and remained inefficient throughout the drilling project. The results of the ineffectiveness of the desander were that the carrying capacity of the drilling fluid was greatly reduced and drill cuttings remained in the borehole. The drill cuttings remaining in the borehole contributed to the washover pipe sticking and breaking numerous times.

\section{Drilling Tool}

The Task Management Plan provided by CEC stated that a drill motor and hydraulic spud-jet system would be used on this project. CEC chose to only provide a hydraulic spud-jet system at the site. However, the clayey nature of the target horizon dictated that a drill motor was required. These wells could have been completed more efficiently by using the drill motor. 
Summary Repart of the Drilling Technologies Tested at the Integrated Demonstration Project for Cleanup of Organic Contaminants in Soils and Groundwater at Non-Arid Sites

\section{Drilling Rig Anchorage}

Anchors were placed at the front of the drilling rig by driving two 10 -foot sections of four-inch diameter washover pipe into the ground and welding them to the frame of the drilling rig. The drilling rig anchors became loose due to excessive pushing and pulling and had to be periodically welded back to the frame. The standard anchor system for the drilling rig consisted of a hydraulic ram and a "dead man" (see Section 4.5.1). The standard anchor system was never employed by CEC.

\subsection{Well Installation Performance}

\subsubsection{Short Radius Drilling Technology}

Well designs were changed significantly from those originally proposed. The original well design for AMH-1 could not be followed because the drilling tools were left in the borehole. Flexible 2-3/8 inch diameter EUE steel tubing with regularly spaced perforations was installed with an inflatable casing packer placed in the casing of the vertical portion of the hole. This well design meets the requirements for air injection.

Attempts to install the originally specified well materials in the borings for AMH-2 met with considerable difficulty. The primary problem encountered was excessive rigidity of the 5-1/2 inch diameter well screen and external casing packer. Though the 5-1/2 inch diameter screen was rapable of negotiating the radius of the curve, it tended to be extremely stiff. Once passing through the curve it retained some of the deformed shape and thus dug into the top of the borehole lateral past the curve. Even using extreme down-pressure, rotation, and back-andforth movement, the screen could not be installed more than 15 to 20 feet past the curve.

Also, the external casing packer and rotary port collar were extremely rigid; their clearances through the curves were extremely small. Clearances between borehole walls and well materials should be maintained to at least one inch on all sides to facilitate installation. Ideally, nothing of greater rigidity than that of the screen should be installed through the curve. The separation of the 2-3/8 inch screen from the rigid external casing packer assembly during an 
Summary Report of the Drilling Technologies Tested at the Integrated Demonstration Project for Cleanup of Organic Contaminants in Soil and Groundwater at Non-Arid Sites

During the first well completion attempt it was obvious that the joints of the Teflon ${ }^{\mathrm{mM}}$ slotted pipe would not withstand the slightest pulling forces. These well materials were designed to be installed in a vertical well and were not designed to undergo the stresses of horizontal well completion. Similarly the PVC casing joints were also designed to be used in a vertical well. The time delay during the well completion to solve the problem of the Teflon ${ }^{\text {TM }}$ joints most likely exacerbated the difficulty of completing the horizontal well. During the waiting period it is likely that the borehole may have partially collapsed on the PVC casing already in the borehole. This would have increased the surface friction and weight of the well materials in the borehole and put additional stress on the casing joints, especially those joints closest to the pulling device.

The well string likely failed at a joint very close to the pulling device because those joints experienced the greatest pulling forces. The well string was approximately 190 feet long. The first joints had passed through the first curved section and had experienced oblique forces which may have deformed the joints. The well string was experiencing key setting in the curved section which increased surface friction, water in the well casing increased the weight of the well materials, and partial collapse of the borehole increased the weight and surface friction of the well materials. Any one of these factors may not have caused failure of the well string, but the combination of all of them was too much for the casing joints to withstand.

The second completion attempt had the same factors working against the well materials, as in the first attempt, plus the factor of solvent/adhesive on the PVC casing joints. The solvent placed on the casing joints softened the PVC prior to application of the adhesive. This in itself would not have caused failure of the joints but the bonding of the joints was not allowed to cure, and the joints may have been weakened as pulling forces were applied before the joints were fully hardened. An inspection of the break in the pin of the second PVC joint showed that the break occurred at the O-ring groove and that the PVC around the groove had been affected by the solvent/adhesive. The $O$-ring groove was machined between the threads on the pin and the straight pipe. The location of the groove created a weakness in the joint and the solvent/adhesive further weakened the joint. 
Summary Report of the Drilling Technologies Tested at the Integrated Demonstration Project for Cleanup of Organic Contaminants in Solls and Groundwater at Non-Arid Sites

The third completion attempt was successful even though the well materials may have experienced high pulling pressures. The fiberglass well materials had the following two advantages (aside from superior tensile strength) over the PVC well materials:

- The fiberglass well materials were in 30-foot lengths. Longer pipe lengths meant fewer joints to break and a greater capability to bend while going through the curved sections. Joints do not bend as readily as straight pipe.

- The joints of the pipes had much thicker walls and consequently were much stronger. The pin and boxes of the joints had no inherent weak spots. For example, the O-ring groove on the fiberglass pin was between the threads and the end of the pin and did not provide a weak spot in the joint.

The successful installation of the horizontal well was directly dependent on the type of well materials used in the third attempt. The following criteria must be considered when choosing completion materials for a horizontal well:

- Compatibility of Materials - In this case it wLs necessary to use materials that could resist the heat generated during the radio frequency heating of the surrounding formation. The Teflon ${ }^{\mathrm{TM}}$ screen fulfilled this criterion but failed to fulfill the following criteria.

- Elexibility of Materials - The radius of curvature of the borehole curve is a factor to consider. The chosen well materials must be able to elastically deform and recover without detrimental effects while moving through the curved sections of the borehole.

- Strength of Materials (Joints) - The joints of the well materials must be able to withstand the pulling forces experienced during well completion. Joints designed for vertical well materials are not able to withstand horizontal well completion forces. 


\subsubsection{River Crossing Industry Drilling Technology}

The well installation method is described in Section 4.5.5. While this method is intuitively simple, it does put stress on the well materials. At any given time each section or joint in the well string experiences the following components of stress:

- Compression-Compression is exerted on the well materials when the drilling rig must be used to push the well construction material from the surface. This technique is necessary to overcome downhole frictional forces. If too much force is exerted, the screen may collapse.

- Weight - The weight of the well string is dependent on the mass of the well materials and upward or downward forces in the borehole. An example of upward force is buoyancy caused by fluid in the borehole. An example of a downward force is the weight of the well string.

This installation method is easy and efficient. The implementation of the method during this drilling project was flawed. Drilling mud was used to install the well materials in AMH-7. The drilling fluid contained a large fraction of fine sediments. The sediments remained in the well after the materials were pushed into place and well development was difficult. A clean, low viscosity, chlorinated drilling fluid should have been used to supply the hydraulic pressure needed to install the well materials.

There appeared to be no problems associated with installation of the sand, bentonite, and grout well seals in the wells.

\subsection{Technolugy Compatibility With Different Geological And Logistical Situations}

The drilling conditions at the IDP site are difficult for most drilling technologies. The most difficult condition for the drilling technologies to overcome is lost drilling fluid circulation. Drilling technologies that do not require drilling fluids have an advantage at this site. 
The river crossing drilling technology was developed to drill through saturated and unsaturated unconsolidated sediments. The drilling technologies adapted from the petroleum industry perform better in consolidated sediments and rock.

\subsubsection{Short Radius Teshnology}

The major advantage to this technology is that the curve can be built in a short horizontal distance (35-ft to 50-ft). This could be an advantage in areas where step-off distance is limited. However, a large area is needed to set-up all the drilling equipment needed for this technology. The disadvantage of this technology is that a steerable bottom hole assembly is difficult or impossible to move though the short radius of the curve. The technology must use a rigid drill mandrel which does not perform well in unconsolidated sediments. Unfortunately, the majority of contaminated sites contain unconsolidated sediments. This drilling technology is best suited for sites that contain consolidated sediments.

\subsubsection{Modified Petroleum Industry Drilling Technology}

This technology can drill curves with radii that range from 90 -ft to 130 -ft. The short radius can allow the technology to be used is areas where step-off distance is limited. However, a large area is needed to set-up all the drilling equipment needed for this technology. The disadvantage to this technology is that drilling is largely dependent on the drilling fluid system. The system must be able to remove drill cuttings from the borehole to prevent the casing from becoming stuck. The underreaming drill bit that must be used to advance casing while drilling has a tendency to wash-out unconsolidated formations. This technology is best suited for drilling in semi-consolidated and consolidated formations.

\subsubsection{Utility Industry Compactional Drilling Technology}

The drilling technology demonstrated during this project can drill a small radius of curvature (<100-ft) and the drilling equipment can be set up in a small area. The compaction drill tool used may be limited to drilling in unconsolidated formation. 
Summary Repart of the Drilling Technologies Tested at the Integrated Demonstration Project for Cleanup of Organic Contaminants in Soil and Groundwater at Non-Arid Sites

\subsubsection{River Crossing Industry Drilling Technology}

This technology requires a large area for equipment set-up and step-off distance. The river crossing technology was developed for drilling in saturated and unsaturated, unconsolidated and consolidated formations and is able to drill in more varied geological conditions than the other drilling technologies. Therefore, this drilling technology should be considered as the most versatile of the drilling technologies demonstrated at this site. 


\begin{tabular}{|c|c|c|c|c|c|c|c|c|c|c|c|c|c|c|}
\hline \multirow{3}{*}{ Borehole } & \multirow{2}{*}{\multicolumn{2}{|c|}{ AMH-1 }} & \multicolumn{2}{|c|}{ AMH-2 } & \multicolumn{2}{|c|}{ AMH-3 } & \multicolumn{2}{|c|}{ AMMH-4 } & \multicolumn{2}{|c|}{ AqMH-5 } & \multicolumn{2}{|c|}{ AMH.6 } & \multicolumn{2}{|c|}{ AMHF- } \\
\hline & cention & & & & & & & & & & & & & \\
\hline & $\frac{P \text { manod }}{39 \pi}$ & $\frac{A c \operatorname{mal}}{35 \AA}$ & $\frac{P \text { Punde }}{39 \pi}$ & $\frac{\mathrm{Atan}}{36 \mathrm{~K}}$ & $\frac{1}{110 \mathrm{~h}}$ & $\frac{A c t}{124 \mathrm{~A}}$ & $\frac{P \text { Pensed }}{110 \mathrm{~A}}$ & $\frac{A c t a n}{62 \pi}$ & $\frac{1000}{200 \AA}$ & $200 \AA$ & 300 & 400 & 300 & 400 \\
\hline 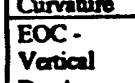 & $154 \pi$ & $150.5 \AA$ & $\begin{array}{l}65 \mathrm{At}- \\
75 \mathrm{R}\end{array}$ & $61.5 \AA$ & $154 \mathrm{~A}$ & $150.8 \mathrm{n}$ & $105 \mathrm{~A}$ & $\overline{102 \pi}$ & $\begin{array}{l}32 \mathrm{AR}- \\
46 \mathrm{At}\end{array}$ & $38 \mathrm{ft}$ & $110 \mathrm{n}$ & $118.6 \mathrm{f}$ & $110 \AA$ & $118.6 \mathrm{n}$ \\
\hline OC. & $57.87^{\circ}$ & $15^{\circ}$ & $57.87^{\circ}$ & $348^{\circ}$ & $170^{\circ}$ & $166^{\circ}$ & $170^{\circ}$ & $179^{\circ}$ & $347^{\circ}$ & $325^{\circ}$ & $53.7^{\circ}$ & $54.1^{\circ}$ & $53.7^{\circ}$ & $54.1^{\circ}$ \\
\hline $\begin{array}{l}\text { Anorizonal } \\
\text { Soction. }\end{array}$ & $57.87^{\circ}$ & $38^{\circ}$ & $57.87^{\circ}$ & $356^{\circ}$ & $170^{\circ}$ & $162^{\circ}$ & $170^{\circ}$ & $164^{\circ}$ & $347^{\circ}$ & $325^{\circ}$ & $53.7^{\circ}$ & $54.1^{\circ}$ & $53.7^{\circ}$ & $54.1^{\circ}$ \\
\hline $\begin{array}{l}\text { Horisomal } \\
\text { Section- } \\
\text { Vertical } \\
\text { Drent }\end{array}$ & $154 \mathrm{ft}$ & $16 \mathfrak{A} \mathfrak{t}$ & $\begin{array}{l}65 \mathrm{f}- \\
75 \mathrm{fh}\end{array}$ & $78.5 \mathrm{ft}$ & $154 \mathrm{ft}$ & $151 \AA$ & $105 \mathrm{ft}$ & $105 \mathrm{nt}$ & $\begin{array}{l}32 \mathrm{ft} \\
46 \mathrm{ft}\end{array}$ & $\begin{array}{l}35 \mathrm{n}- \\
38 \mathrm{n}\end{array}$ & $110 \mathrm{ft}$ & $118.6 \mathrm{n}$ & $110 \mathrm{ft}$ & $118.6 \mathrm{n}$ \\
\hline Borehole & $\begin{array}{l}\text { andilly } \\
\text { Borthol } \\
\text { Portatem }\end{array}$ & $\begin{array}{l}\text { Subility } \\
\text { Nonoded in }\end{array}$ & $\begin{array}{l}\text { Borethol } \\
\text { Problem }\end{array}$ & $\begin{array}{l}\text { Sublitity } \\
\text { Noted in }\end{array}$ & $\begin{array}{l}\text { Suble. } \\
\text { Durin }\end{array}$ & $\begin{array}{l}\text { Chole } \\
\text { Well }\end{array}$ & $\begin{array}{c}\text { Subb } \\
\text { D }\end{array}$ & $\begin{array}{l}\text { Thole } \\
\text { Well }\end{array}$ & Subble I & orthole & Subble & orcthole & Stabbel & Borthole \\
\hline Removal of & $\frac{\text { Orising }}{\text { Poor C }}$ & Uturings & & trings & $\begin{array}{c}\text { Poor } \\
\text { Ren }\end{array}$ & Counings & $\begin{array}{l}\text { Poor } \\
\text { Rer }\end{array}$ & $\begin{array}{l}\text { uninge } \\
\text { ovel }\end{array}$ & & taing & $\begin{array}{c}\text { Poor } \\
\text { Ra }\end{array}$ & ovel & & torning \\
\hline Stin & Exrowasivi & $\begin{array}{l}\text { EDilling } \\
\text { Luces }\end{array}$ & $\frac{\text { Minim }}{\mathbf{D}_{\text {E }}}$ & 1 Stin & $\begin{array}{c}\text { Minim } \\
\text { D }\end{array}$ & nat Skin & $\underset{\text { Dinin }}{\text { Mini }}$ & i) Skin & $\underset{\text { D. Minim }}{\text { Min }}$ & 1 Stin & $\begin{array}{c}\text { Excossin } \\
\text { Flai }\end{array}$ & Doulling & $\begin{array}{r}\text { Exoo } \\
F \\
\end{array}$ & EDilling \\
\hline
\end{tabular}


CDM Federal Programs Corporation October 15, 1993

Summary Report of the Drilling Technologies Tested at the Integrated Demonstration Project for Cleanup of Organic Contaminants in Soil and Groundwater at Non-Arid Sites

\section{THIS PAGE LEFT INTENTIONALLY LEFT BLANK}




\subsection{COST COMPARISON OF THE DRILLING PROJECTS}

The drilling projects in this demonstration had varying objectives and used different drilling technologies, equipment, and personnel. In addition, the technologies demonstrated were relatively new or experimental. Thus, a comparison of costs between the drilling projects is difficult and therefore this section contains a general discussion of the costs associated with drilling a horizontal environmental well. There is a brief discussion of the cost for each of the drilling projects (except for AMH-5) and how those costs compare with average industry costs for installing horizontal environmental wells.

\subsection{Cost Associated with Drilling a Horizontal Environmental Well}

The most common method of describing the expense of installing a vertical well is the ratio of cost per foot of drilling. An environmental problem holder may use this ratio to compare the drilling costs for vertical wells installed with similar methods, in similar geologic conditions, and with similar materials. Horizontal drilling contractors have resisted using a cost/ft ratio to describe the expense of installing a horizontal well because there are several factors that determine the expense of installing a horizontal environmental well and a cost/ft ratio can only be used in specific cases when drilling factors are the same. Drilling factors are listed below.

- Risk. Each drilling project entails an amount of risk of losing equipment and well materials down a hole and of damaging equipment. The risk can be shared by the environmental problem holder and the drilling contractor, or the onus can be entirely placed on the drilling contractor. The cost of the drilling project is proportional to the amount of risk that the drilling contractor bears.

- The size of the drilling rig. Large drilling rigs require greater mobilization costs than small drilling rigs due to permits, fuel, insurance, and tractor and/or trailer rental rates. The daily charge of the drilling rig is based on the original capital cost, daily maintenance, etc. of the equipment; therefore, larger drilling rigs will have a greater daily rental rate. 
Summary Report of the Drilling Technologies Tested at the Integrated Demonstration Project for Cleanup of Organic Contaminants in Soil and Groundwater at Non-Arid Sites

- The type of drilling tool or down-hole mud motor. The drilling tool or down-hole mud motor may be rented or owned by the driller. The daily rate for this equipment will increase with its complexity. The replacement cost of the drilling tools and down-hole mud motors will increase the risk factor in the project cost if there is a perceived danger that this equipment may become stuck in the borehole.

- The type of guidance system. Guidance systems vary from relatively simple radio beaconreceiver systems to very sophisticated guidance systems similar to those used in aeronautics. The guidance system may be rented or owned by the drilling company. The daily rate for this equipment will increase with its complexity. The replacement cost of the guidance system will increase the risk factor in the project cost. Radio beacon-receiver guidance systems can only be used at depths less than $25 \mathrm{ft}$; therefore, drilling projects at greater depths will necessarily have the additional cost of a more sophisticated guidance system.

- The use of a secondary confirmation survey for the guidance system. A secondary survey is needed to accurately locate the down-hole magnetic guidance tool in areas that have magnetic interferences. Such a survey will increase the daily rate of the drilling project.

- The use of a drilling fluid system. The complexity and cost of the drilling fluid system will depend on the geologic drilling conditions and the drilling method used. In general, drilling below the water table requires a drilling fluid system, especially if the sediment is unconsolidated. The drilling fluid system will increase the daily rate of the drilling project.

- The number of personnel. Personnel will add to the daily cost of the drilling project. Large drilling rigs require larger crews than smaller drilling rigs, and sophisticated drilling programs require highly skilled and more expensive drillers. Drilling projects that involve shallow, low risk drilling can be performed by less experienced personnel. 
- The type and amount of well materials. In general, horizontal well installations, particularly in continuous boreholes, will put a greater stress on well materials than the stress experienced in vertical well installations. Well materials that can withstand the additional stress will increase the project cost. Pre-pack well screens are commonly used in horizontal wells because of the difficulty of installing a filter pack in a horizontal well. The pre-pack well screens will increase the cost of the drilling project. Large horiz ontal wells require more material and are therefore more expensive.

The factors listed above do not include considerations for the cost of designing the horizontal well and the management of the field effort. Depending on the sophistication of the horizontal well system and the length of time it takes to install the horizontal well system, these costs may be substantial.

\subsection{Drilling Costs Obtained from an Industry Survey}

A catalogue of horizontal environmental well installations was created from a survey conducted by SRTC of the horizontal environmental well industry (WSRC-TR-93-511). The catalogue includes costs of most of the horizontal well installations. These costs may be used to estimate a cost/ft drilling expense with the caveat that above listed cost factors must be considered when comparing the cost/ft of horizontal wells and drilling contractors. The costs of the horizontal well installations have been broken down by drilling method and vertical depth of the well screen and well materials.

\subsubsection{Directional Drilling Method and Vertical Depth}

The method used to directionally drill a horizontal borehole depends on the site geology and the vertical depth of the horizontal well. There are two methods for directional drilling at VD less than 25-ft. 
Summary Report of the Drilling Technologies Tested at the Integrated Demonstration Project for Cleanup of Organic Contaminants in Soil and Groundwater at Non-Arid Sites

The less expensive directional drilling method of the two uses a small to medium size utility type drilling rig, a radio beacon/receiver, "walk-over" guidance system, a simple drilling fluid system, and a compactional drilling tool. The guidance system used in this method limits the drilling depth to less than 25-ft; the drilling fluid system and the drilling tool limit the method to appropriate geologic conditions. The average cost/ft for horizontal wells constructed from PVC or HDPE materials and installed (using this method) at less than 25-ft VD was $\$ 50 / \mathrm{ft}$.

A more sophisticated directional drilling method uses larger drilling rigs, a magnetometer/accelerometer guidance system and a more sophisticated drilling fluid system and drilling tool. This method is not limited by depth or geologic conditions. The average cost/ft for horizontal wells constructed from PVC or HDPE materials and installed (using this method) at less than 25-ft VD was $\$ 316 / \mathrm{ft}$; for vertical depths between 25 -ft and 100 -ft the average cost was $\$ 186 / \mathrm{ft}$; for vertical depths greater than $100-\mathrm{ft}$ the average cost was $\$ 227 / \mathrm{ft}$. The increase in cost for vertical depths less than 25 - $\mathrm{ft}$ is caused by the short drilled length of the shallow boreholes and the fixed mobilization and daily costs for the equipment used in this method. In otherwords, the cost/ft is less for longer boreholes.

\subsubsection{Well Materials}

Horizontal well materials may be constructed entirely of, or a combination of, PVC, HDPE, and stainless steel. The well screen may be a simple slotted pipe or may have a pre-packed filter pack. The average cost/ft of installing horizontal wells with casing and screens of PVC or HDPE materials was approximately one half of the average cost of installing wells that had stainless steel casing and screen and/or a pre-packed filter on the screen.

\subsection{Cost Breakdown for Directional Drilling Projects}

This section contains a discussion of the reported costs of the horizontal well projects at SRS. The costs are then compared to the average costs calculated from the horizontal well survey. 
Summary Report of the Drilling Technologies Tested at the Integrated Demonstration Project for Cleanup of Organic Contaminants in Soils and Groundwater at Non-Arid Sites

The first drilling project used a short radius drilling technology (described in Section 4.2) taken directly from the petroleum industry. The costs of the project to the SRTC were associated with directional drilling and expertise of Eastman Christensen, and the drilling equipment of Graves Well Drilling Company. The cost associated with the project is listed in Table 6-1.

\begin{tabular}{|c|c|c|c|c|}
\hline Drilling Project & Cost & $\begin{array}{c}\text { Linear Feet of } \\
\text { Well Installation }\end{array}$ & Project Cost/ft & $\begin{array}{c}\text { Average } \\
\text { Industry Cost } / \mathrm{ft}\end{array}$ \\
\hline Short Radius & $\$ 963,730$ & $768-\mathrm{ft}$ & $\$ 1255$ & $\$ 150-\$ 250$ \\
\hline $\begin{array}{c}\text { Modified } \\
\text { Petroleum }\end{array}$ & $\$ 235,350$ & $788-\mathrm{ft}$ & $\$ 299$ & $\$ 150-\$ 250$ \\
\hline River Crossing & $\$ 230,000$ & $1440-\mathrm{ft}$ & $\$ 160$ & $\$ 227$ \\
\hline
\end{tabular}

\section{Table 6.1 Associated Cost for Drilling Projects}

The second project used a modified petroleum industry drilling technology. The costs of the project to the SRTC were associated with engineering and directional drilling services and equipment delivered by Eastman Christensen, and the drilling support activities of Graves Well Drilling Company. The cost associated with the project is listed in Table 6.1.

The third project used a utility industry compactional drilling technology. Because Ditch Witch installed this well as a demonstration, there were no costs incurred by SRTC. Therefore, costs for this project are not listed in Table 6.1

The fourth project used a modified river crossing industry drilling technology. The costs of the project to the SRTC were associated with engineering and directional drilling services and equipment performed by CEC. The cost associated with the project is listed in Table 6-1. 
Summary Report of the Drilling Technologies Tested at the Integrated Demonstration Project for Cleanup of Organic Contaminants in Soil and Groundwater at Non-Arid Sites

\subsection{Discussion of Potential Cost Saving Measures for Future Drilling}

The costs of drilling and installing horizontal environmental wells may be reduced by keeping the costs of the project as close to the environmental problem holder as possible. The environmental problem holder should perform as many of the following functions as prudent.

- Design the horizontal well.

- Purchase the well materials.

- Contract the services of the directional drilling company.

- Provide drilling support services, such as waste storage and handling.

- Provide drilling oversight services. 


\subsection{CONCLUSIONS}

Four directional drilling technologies were demonstrated during this project; Table 7.1 list the advantages and disadvantages of each technology. A short discussion of the present state of each of the technologies is presented below.

The short radius drilling technology was developed in the petroleum industry and was used at the IDP site with little modification. A recent survey of the horizontal environmental well industry did not find another site where this technology was used to install a horizontal environmental well.

The modified petroleum industry drilling technology has been modified further to drilling in shallow, unconsolidated formations. The major modification is that an additive to the drilling fluid allows the well screen to be installed in an open borehole. This modification does not require the well screen to be pulled into the hole behind the drill motor. This technology is currently being used to install horizontal environmental wells.

The utility industry drilling technology demonstration has lead to a new drilling rig product line for Charles Machine Works. The prototype drilling rig and drilling tool are currently being used to install horizontal environmental wells.

The river crossing industry drilling technology used during this project has undergone modification. The washover drilling pipe that proved inadequate during the project has been replaced with stronger pipe by the company that conducted the demonstration. It must be noted that the technique used during this project is one of many techniques used in the river crossing industry to install pipes in the subsurface. 
Summary Report of the Drilling Technologies Tested at the Integrated Demonstration Project for Cleanup of Organic Contaminants in Soil and Groundwater at Non-Arid Sites

\begin{tabular}{|c|c|c|c|}
\hline $\begin{array}{l}\text { Short Radius } \\
\text { Technology }\end{array}$ & $\begin{array}{l}\text { Modified } \\
\text { Petroleum } \\
\text { Technology }\end{array}$ & $\begin{array}{l}\text { Utility } \\
\text { Technology }\end{array}$ & $\begin{array}{l}\text { River Crossing } \\
\text { Technology }\end{array}$ \\
\hline \multicolumn{4}{|c|}{ Advantages } \\
\hline $\begin{array}{l}\text { Minimum Step-off } \\
\text { Distance }\end{array}$ & Shon Step-off Distance & $\begin{array}{l}\text { Minimum Drilling } \\
\text { Fluids }\end{array}$ & $\begin{array}{l}\text { Maximum Borehole } \\
\text { Control }\end{array}$ \\
\hline \multirow[t]{4}{*}{$\begin{array}{l}\text { Can Drill in } \\
\text { Consolidated Formations }\end{array}$} & $\begin{array}{l}\text { Can Drill in } \\
\text { Consolidated Formations }\end{array}$ & $\begin{array}{l}\text { Minimum Secondary } \\
\text { Waste }\end{array}$ & $\begin{array}{l}\text { Maximum Down-hole } \\
\text { Directional Control }\end{array}$ \\
\hline & & $\begin{array}{l}\text { Good Down-hole } \\
\text { Directional Control }\end{array}$ & $\begin{array}{l}\text { Maximum Flexibility in } \\
\text { Well Materials }\end{array}$ \\
\hline & & $\begin{array}{l}\text { Flexibility in Well } \\
\text { Materials }\end{array}$ & May Install Filter Pack \\
\hline & & Minimum Set-up Area & $\begin{array}{l}\text { Can Drill in } \\
\text { Consolidated Formations }\end{array}$ \\
\hline \multicolumn{4}{|c|}{ Disadvantages } \\
\hline Large Set-up Area & Large Set-up Area & $\begin{array}{l}\text { Limited to } \\
\text { Unconsolidated } \\
\text { Formations }\end{array}$ & Large Set-up Area \\
\hline $\begin{array}{l}\text { High Volume of } \\
\text { Secondary Waste }\end{array}$ & $\begin{array}{l}\text { High Volume of } \\
\text { Secondary Waste }\end{array}$ & Longer Step-off Distance & $\begin{array}{l}\text { High Volume of } \\
\text { Secondary Waste }\end{array}$ \\
\hline $\begin{array}{l}\text { Doesn't Perform Well in } \\
\text { Unconsolidated } \\
\text { Formations }\end{array}$ & $\begin{array}{l}\text { Well Installation } \\
\text { Depends Heavily on } \\
\text { Drilling Fluid System }\end{array}$ & $\begin{array}{l}\text { Borehole Skin Darnage } \\
\text { May be Extensive in } \\
\text { Clay Formations }\end{array}$ & Longer Step-off Distance \\
\hline \multicolumn{4}{|l|}{$\begin{array}{l}\text { Poor Down-hole } \\
\text { Directional Control }\end{array}$} \\
\hline \multicolumn{4}{|l|}{$\begin{array}{l}\text { Lack of Borehole Control } \\
\text { During Well Installation }\end{array}$} \\
\hline \multicolumn{4}{|c|}{$\begin{array}{l}\text { Projected Cost for Drilling Compared to Industry Average } \\
\text { Costs are in dollar per foot of installed well }\end{array}$} \\
\hline $\begin{array}{c}\text { Project - \$1255 } \\
\text { Industry - } \$ 150-\$ 250\end{array}$ & $\begin{array}{c}\text { Project - \$299 } \\
\text { Industry - \$150 - \$250 }\end{array}$ & $\begin{array}{l}\text { Work performed under } \\
\text { industrial partnership. } \\
\text { No drilling costs } \\
\text { submitted to WSRC }\end{array}$ & $\begin{array}{l}\text { Project - \$160 } \\
\text { Industry - \$227 }\end{array}$ \\
\hline
\end{tabular}

Table 7.1 List of Advantages and Disadvantages of Each Technology 
Summary Report of the Drilling Technologies Tested at the Integrated Demonstration Project for Cleanup of Organic Contaminants in Soils and Groundwater at Non-Arid Sites

\subsection{RECOMMENDATIONS}

The following are general recommendations for design and installation of horizontal environmental wells.

1. Pre-drilling activities should include:

- A thorough description of the target zone and surrounding geology should be made available to the well designers and the drilling subcontractor.

- A description of the well completion requirements such as well screen size, filter pack size (if needed), and specifications of the well string material should be made available to the well designers and the drilling subcontractor.

- A thorough design of the borehole should be prepared. The design should include the locations of the entry hole and exit hole (if needed), the location of the well screen, and the radius of curvature required to place the well screen correctly.

- An engineering calculation brief that describes and sums the forces experienced by the well materials during well completion activities. The calculation brief should delineate the strength requirements of the well materials and evaluate the utility of the chosen well materials.

- The chosen well materials should be thoroughly inspected before well completion activities begin. Special emphasis should be placed on the pin and box of each piece if threaded joints are used.

- The steering tool should be calibrated onsite by a qualified technician before each use.

- The drilling subcontractor should be procured as early on in the design proress as possible. Pre-drilling meetings should be held, and all the above items should be discussed with the drilling subcontractor. 
2. Surface-launched boreholes require that the drilling rig is anchored firmly to the ground and that the anchorage is able to resist the maximum pushing and pulling capacity of the drilling rig.

3. The steering system should be proven as an accurate survey tool or have a secondary survey to confirm the location of the down-hole assembly.

4. The drilling contractor should provide an experienced drilling crew. The drilling crew should be experienced in:

- Installing a horizontal well in conditions similar to that found at the proposed drilling site.

- The use of all equipment used to install the horizontal well.

5. There should be a drilling fluid engineer on site if drilling fluids are used.

6. The drilling crew should make every effort to control the loss of drilling fluid circulation. Loss circulation zones should be plugged when they are encountered.

7. When using a guar gum-based drilling fluid a chlorine additive should be used in the drilling fluid mix water and development water to disinfect the drilling fluid and inhibit bacterial growth. If the state Health Department does not allow a disinfectant to be introduce to the subsurface, then an alternate drilling fluid (such as a bentonite based drilling fluid) should be used.

8. If hydraulic pressure is used to install the well materials, a clean, chlorinated, drilling fluid should be used. A clean drilling fluid would not introduce drill cuttings into the well materials that would increase well development efforts. 
Summary Report of the Drilling Technologies Tested at the Integrated Demonstration Project for Cleanup of Organic Contaminants in Soils and Groundwater at Non-Arid Sites

9. Drilling crews should be required to keep detailed daily records of drilling activities and drilling fluid properties. The records can be used to adapt drilling methods to site conditions.

10. Radii of curvature for the boreholes should be large enough to accommodate the drilling materials. Future drilling projects that use similar washover pipe should be designed to have a borehole with a radius of curvature greater than 400 feet.

11. Longer drill pipe and a wireless drilling survey system would greatly decrease the drilling time. 
Summary Report of the Drilling Technologies Tested at the Integrated Demonstration Project for Cleanup of Organic Contaminants in Soil and Groundwater at Non-Arid Sites

\section{THIS PAGE LEFT INTENTIONALLY LEFT BLANK}




\section{REFERENCES}

Aadland, R.K., Smits, A.D., and Thayer, P.A., 1992, Geology and Hydrostratigraphy of the A/M Area, Savannah River Site (SRS), South Carolina (U)

CDM Federal Programs Corporation, 1992, Hydrogeologic Setting of the A/M Area: Framework for Groundwater Transport, Second Draft, WSRC-TR-92-355.

Eddy, C.A., Looney, B.B., Dougherty, J.M., Hazen, T.C., and Kaback, D.S., 1991, Characterization of the Geology, Geochemistry, Hydrology and Microbiology of the In-Situ Air Stripping Demonstration Site at the Savannah River Site, USDOE Report WSRC-RD-9121, Westinghouse Savannah River Co., Savannah River Laboratory, Aiken, SC 29808, 118p

Huddleston, P.F., and Hetrick, J.H., 1985, Upper Eocene Stratigraphy of Central and Eastern Georgia. Georgia Geologic Survey Bulletin 95, 78 p

Kaback, D.S., et.al., August 1989 Well Completion Report on Installation of Horizontal Wells for In-Situ Remediation Tests, WSRC-RP-89-784

Nystrom, P.G., Jr., and Willoughby, R.H., 1982, "Cretaceous, Tertiary, and Pleistocene(?) Stratigraphy of Hollow Creek and Graniteville Quadrangles, Aiken County, South Carolina", in Nystrom, P.G., Jr., and Willoughby, R.H., eds., 1982, Geological Investigations Related to the Stratigraphy in the Kaolin Mining District, Aiken County, South Carolina. Carolina Geological Society Field Trip Guidebook 1982, South Carolina Geological Survey, Columbia, SC, pp 80-113

Nystrom, P.G., Jr., Willoughby, R.H., and Kite, L.E., 1986, Cretaceous-Tertiary Stratigraphy of the Upper Edge of the Coastal Plain Between North Augusta and Lexington, South Carolina. Carolina Geological Society Field Trip Guidebook, South Carolina Geological Survey 
Summary Report of the Drilling Technologies Tested at the Integrated Demonstration Project for Cleanup of Organic Contaminants in Soil and Groundwater at Non-Arid Sites

Science Applications International Corporation, 1992, Construction Notes and Summary of Hydrostratigraphy for Hydrogeologic Cross-Sections for the Integrated Demonstration Site, Savannah River Site. SAIC, 360 Bay Street, Suite 200, Augusta, GA 30901

Siple, G.E., 1967, Geology and Groundwater of the Savannah River Plant and Vicinity, South Carolina. U.S. Geological Survey Water-Supply Paper 1841, 113 p

WSRC, December 1992, Demonstration of Eastman Christensen Horizontal Drilling System Integrated Demonstraton Site Savannah River Site WSRC-TR-92-577

WSRC, December 1992, Demonstration of A Utility Indusrtry Horizontal Drilling System: Horizontal Well AMH-5 Installation Report WSRC-TR-93-008

WSRC, May 1993, Demonstration of River Crossing Technology for Installation of Environmental Horizontal Wells: AMH-6 and AMH-7 Installation Report WSRC-TR-93-387 
Summary Report of the Drilling Technologies Tested at the Integrated Demonstration Project for Cleanup of Organic Contaminants in Soils and Groundwater at Non-Arid Sites

\section{DRILLING FLUID REFERENCES}

WSRC is aware of the large amounts of drillng fluid that was lost to the host formations during the installation of the horizontal wells. The following is a list of references created during a literature search for technical papers that discussed the effects of drilling fluids on the host formation. The search was conducted as a first step in a study to determine the geochemical effects of guar gum and bentonite based drilling fluids to formation water and lithologies.

Ahlness, J.K., D.I. Johnson, D.R. Tweeton, 1984, Effect of Drilling Fluids on Permeability of Uranium Sandstone, U.S. Bureau of Mines Report of Investigations, RI-8914.

Brobst, R.B., P.M. Buszka, 1986, The Effect of Three Drilling Fluids on Ground Water Sample Chemistry, Ground Water Monitoring Review, vol. 6, no. 1, pp 62-70.

Brown, K.W., D.C. Anderson, 1983, Effects of Organic Solvents on the Permeability of Clays, U.S. Environmental Protection Agency Project Summary, EPA-600/S2-83-016.

Dudgeon, C.R., R.J. Cox, 1976, Drilling Mud Invasion of Unconsolidated Aquifer Materials, Australian Water Resources Council Technical Paper No. 17, Research Project No. 71/25, Australian Government Publishing Service, Canberra.

Howsam, P.,R. Hollamby, 1990, Drilling Fluid Invasion and Permeability Impairment in Granular Formations, Quarterly Journal of Engineering Geology, London, vol. 23, pp. 161-168.

Gibb, J., 1987, How Drilling Fluids and Grouting Materials Affect the Integrity of Ground Water Samples from Monitoring Wells. Ground Water Monitoring Review, vol 7, no. 1, pp. 33-35.

McGlothlin, R.E., 1980, Water Base Drilling Fluids, Symposium Proceedings, vol. 1: Research on Environmental Fate of Drilling Fluid and Cuttings, January 21-24, 1980, Lake Buena Vista, Florida. pp.30-37. 
Summary Report of the Drilling Technologies Tested at the Integrated Demonstration Project for Cleanup of Organic Contaminants in Soil and Groundwater at Non-Arid Sites

Nelson, D.W., L. Shyilon, L.E. Sommers, 1980, Plant Uptake of Toxic Metals Present in Drilling Fluids, Symposium Proceedings, vol. 1: Research on Environmental Fate of Drilling Fluid and Cuttings, January 21-24, 1980, Lake Buena Vista, Florida. pp.1529.

Perricone, C., 1980, Major Drilling Fluid Additives - 1979. Symposium Proceedings, vol. 1: Research on Environmental Fate of Drilling Fluid and Cuttings, January 21-24, 1980, Lake Buena Vista, Florida. pp.15-29.

Richard, M.R., 1979a, The Organic Drilling Fluid Controversy: Part I. Water Well Journal, April, pp. 66-74.

Richard, M.R., 1979b, The Organic Drilling Fluid Controversy: Part II. Water Well Journal, April, pp. 50-59.

Spooner, P.A., G.E. Hunt, V.E. Hodge, P.M. Wagner, I.R. Melnyk, 1984, Compatiblity of Grouts with Hazardous Wastes, U.S. Environmental Protection Agency Project Summary, EPA-600/S2-84-015.

Stavrngin, A.N., B.G. Tarasov, O.A. Shirkes, I.A. Mekhnetsov, S.T. SAvitskii, 1993, Permeability of Rocks and Effectiveness of Maintaining the Stability of Deep and Superdeep Boreholes by Drilling Mud Pressure, Journal of Mining Science, vol. 28, no. 5, pp. 401-410.

Strosher, M.T., 1980, Characterization of Organic Constituents in Waste Drilling Fluids, Symposium Proceedings, vol. 1: Research on Environmental Fate of Drilling Fluid and Cuttings, January 21-24, 1980, Lake Buena Vista, Florida. pp.70-97.

Walker, S.E., 1983, Background Ground-Water Quality Monitoring: Well Installation Trauma, Proceedings of the Third National Symposium on Aquifer Pestoration and DroundWater Monitoring; May 25-27, Columbus, OH. pp. 235-246. 
Summary Report of the Drilling Technologies Tested at the Integrated Demonstration Project for Cleanup of Organic Contaminants in Soils and Groundwater at Non-Arid Sites

Younkin, W.E., D.L. Johnson, 1980, The Impact of Waste Drilling Fluids on Soils and Vegetation in Alberta, Symposium Proceedings, vol. 1: Research on Environmental Fate of Drilling Fluid and Cuttings, January 21-24, 1980, Lake Buena Vista, Florida. pp.15-29.

Zitko, V., 1975, Toxicity and Environmental Properties of Chemicals Used in Well Drilling Operations. Conference Proceedings: Environmental Aspects of Chemical Use in WellDrilling Operations, May 1975, Houston TX, U.S. Environmental Protection Agency, Office of Toxic Substances, Washinton, D.C., pub.no. EPA-560/1-75-004. pp. 311332. 

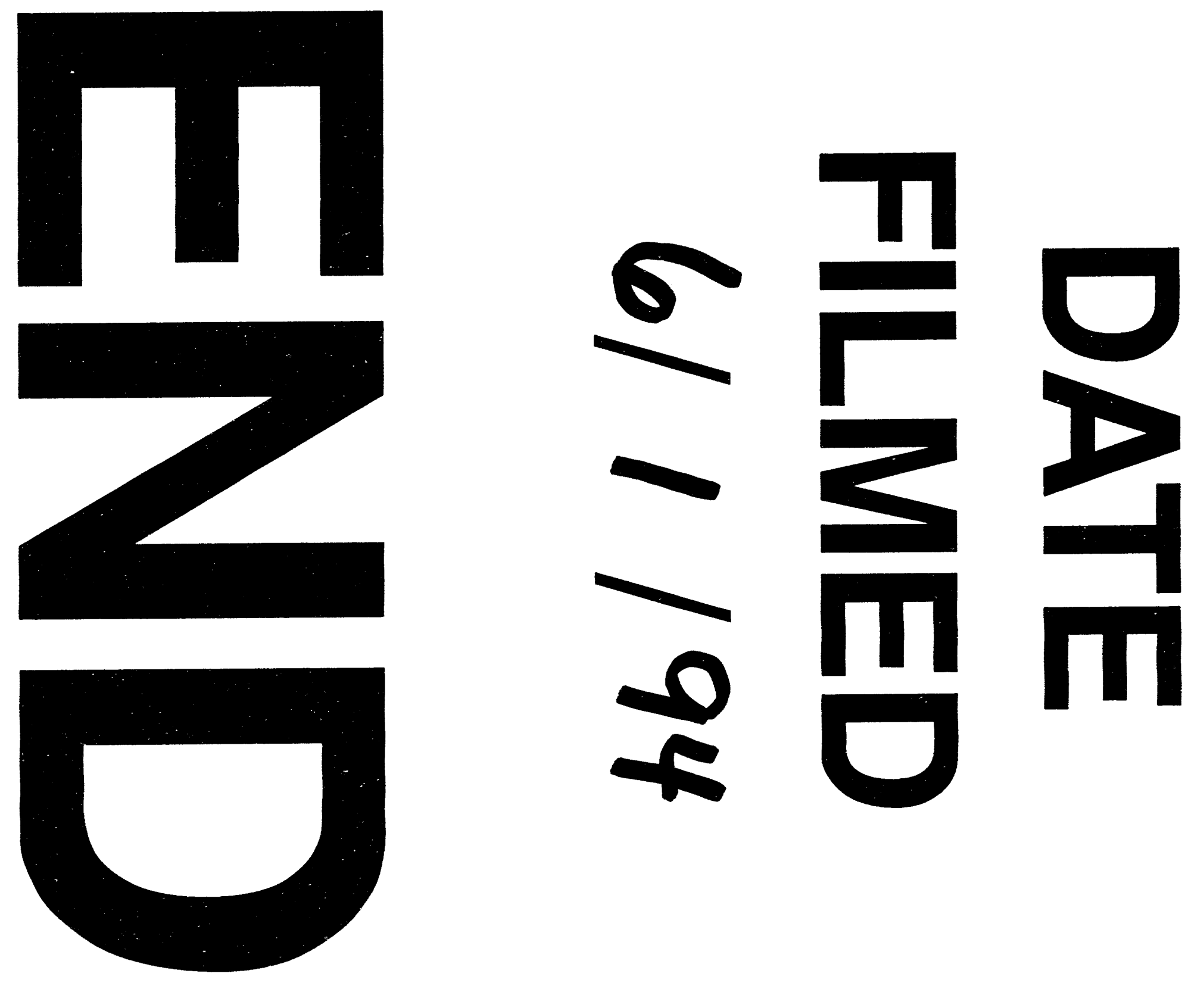


\section{$\overline{-}-\overline{-}$

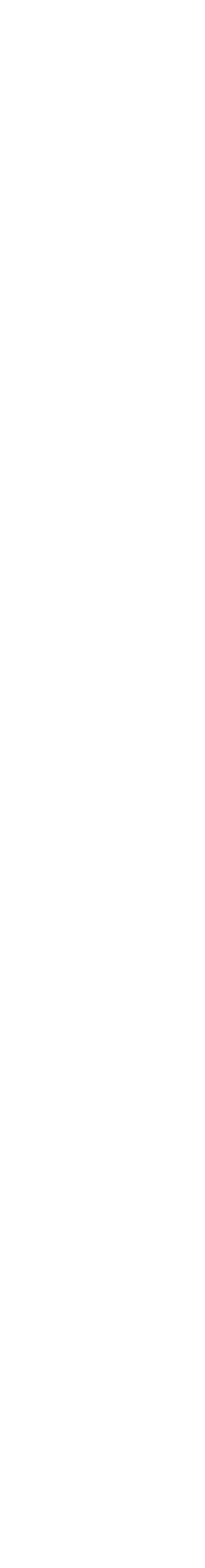
.
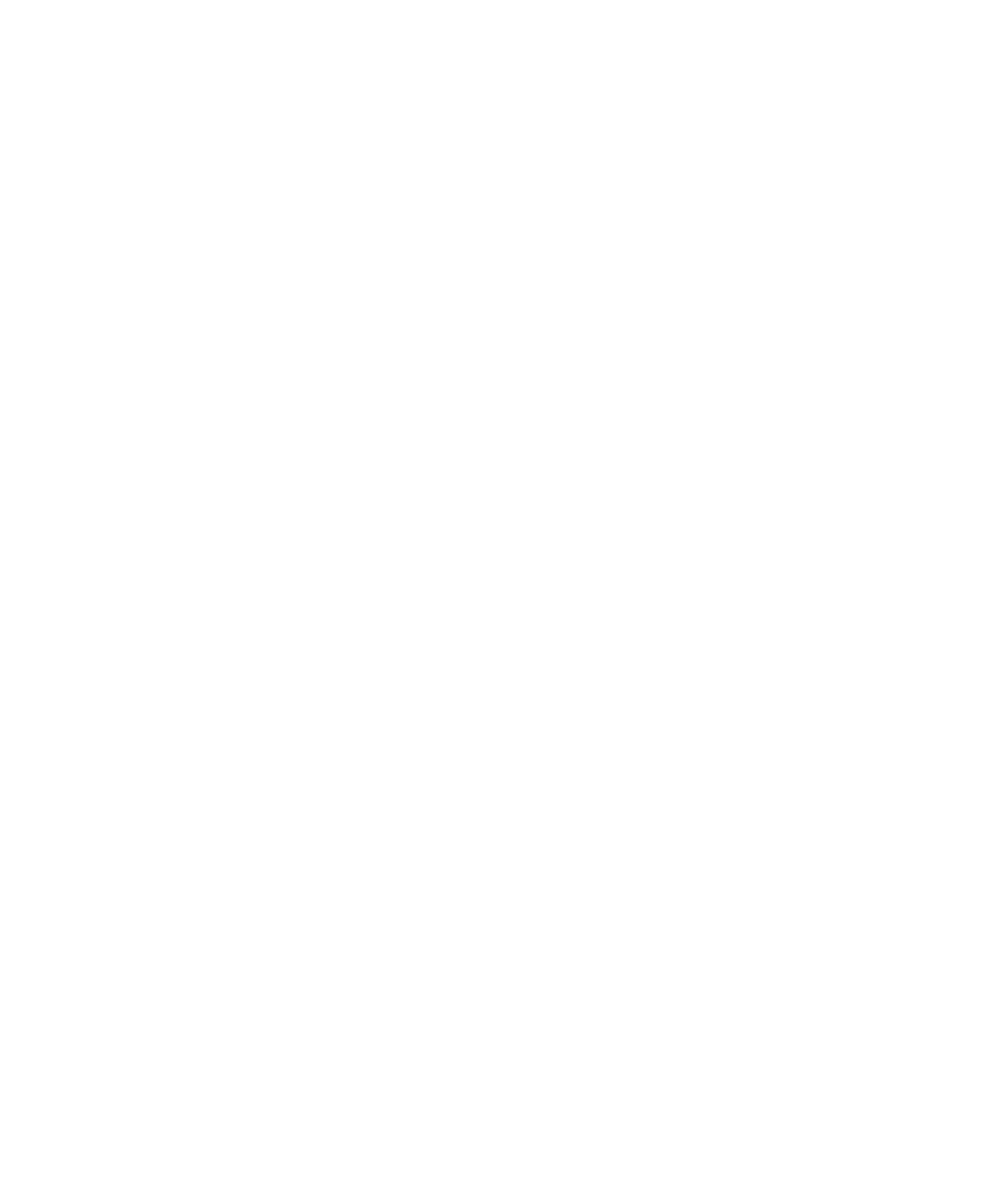